\title{
GSSA
}

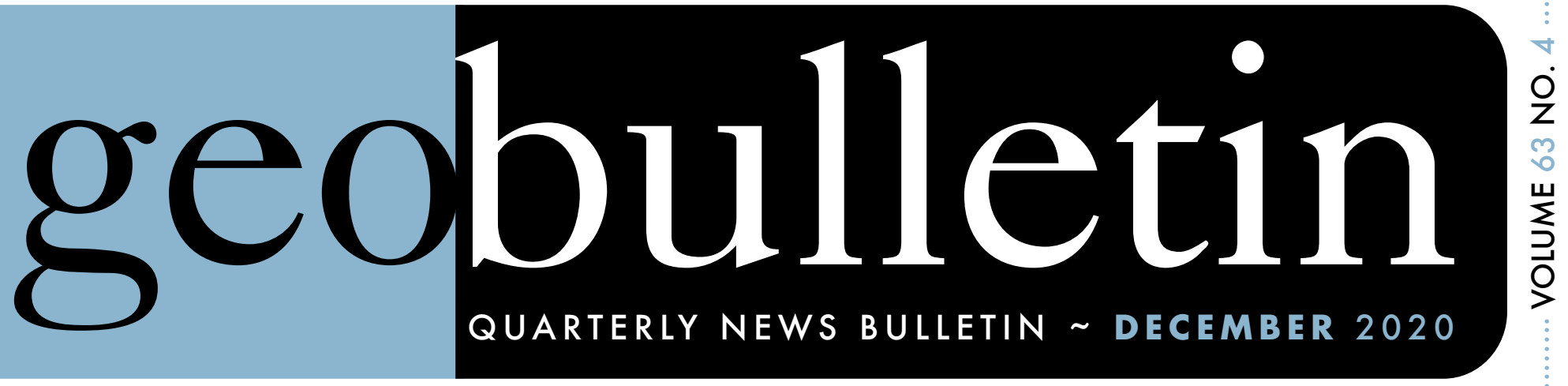

What does the "New Normal" mean? Geological travels: Nepal Transvaal Jade / Grossular garnet 


\section{REGISTRATION WITH}

\section{SACNASP \\ South African Council for Natural Scientific Professions}

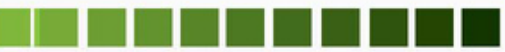
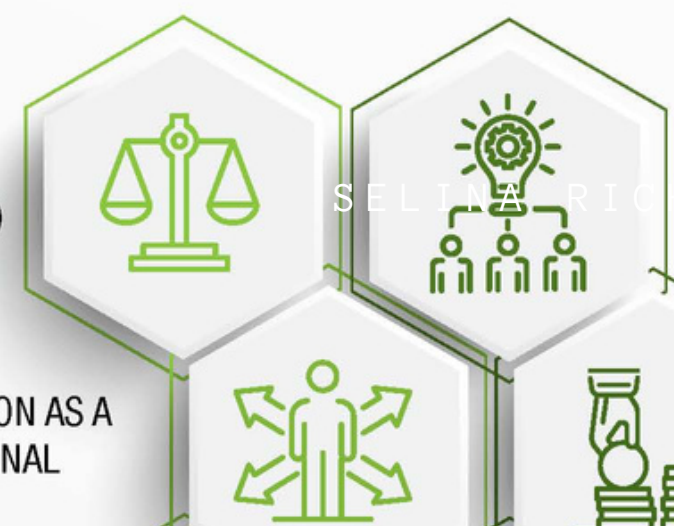

RT NETWORKING -

WEBINARS, WEBSITE

NETWORKING PORTAL

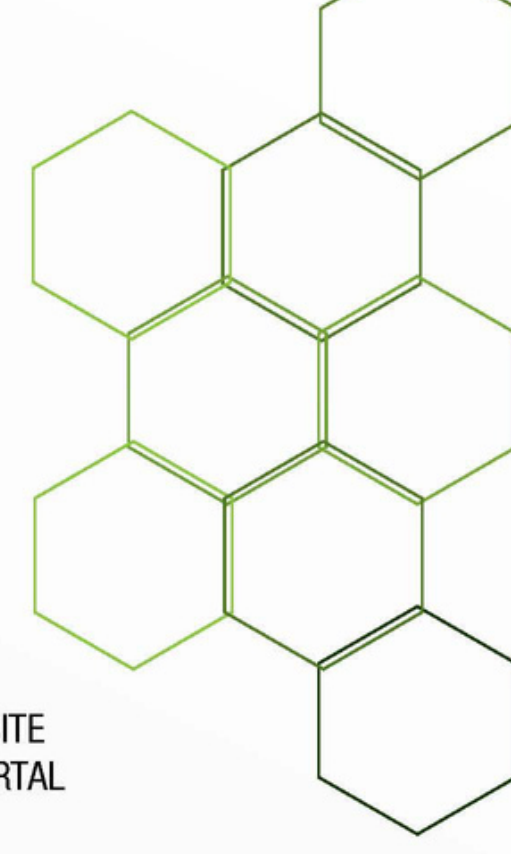

03

PROFESSIONAL

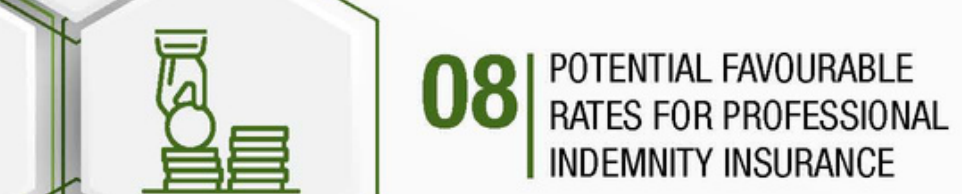

PUBLIC

CONFIDENCE IN YOU AS A SCIENTIST

MARKETABILITY (EMPLOYERS REQUIRE REGISTRATION)

04

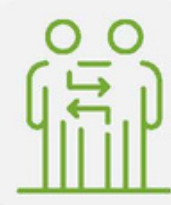

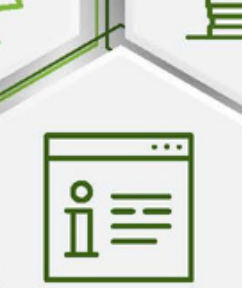
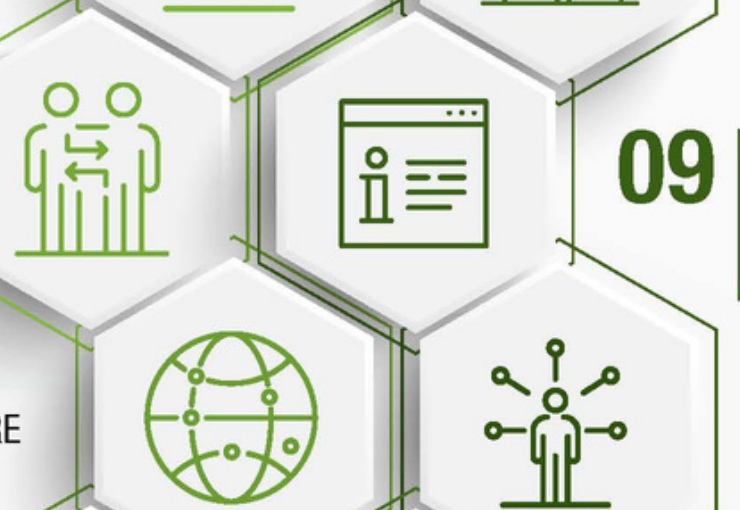

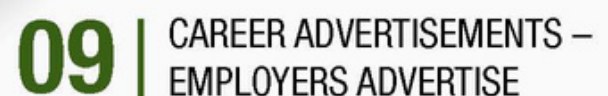

EMPLOYERS ADVERTISE

VACANCIES ON SACNASP

WEBSITE AND SOCIAL MEDIA

10 VOLUNTARY ASSOCIATION EVENTS -

\section{0}

05

CODE OF CONDUCT - TRUST FOR ETHICAL VALUES NETWORK WITH FIELD OF PRACTICE PEERS AND GAIN VOCATIONAL CAREER ADVICE

\section{T}

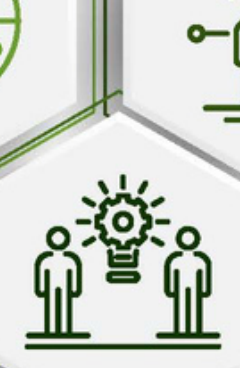

11

FACILITATES LIFELONG LEARNING THAT IS

CRUCIAL TO A PROFESSIONAL'S CAREER

PATH - CANDIDATE MENTOR PROGRAMME

Of INPUT TO GOVERNMENT SACNASP VOICING SCIENTISTS' INPUT AT MINISTERIAL LEVEL

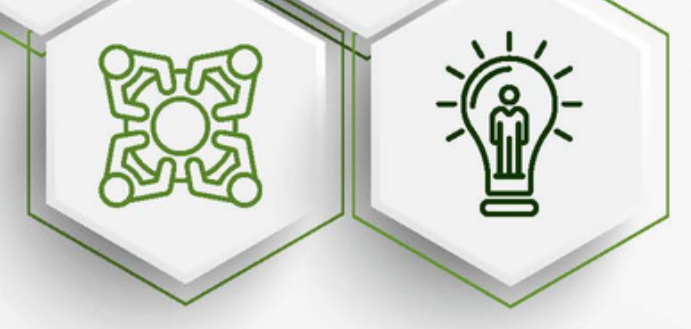

12

CONTINUING PROFESSIONAL

DEVELOPMENT - ONLINE

LEARNING

\section{GMP and GPD}

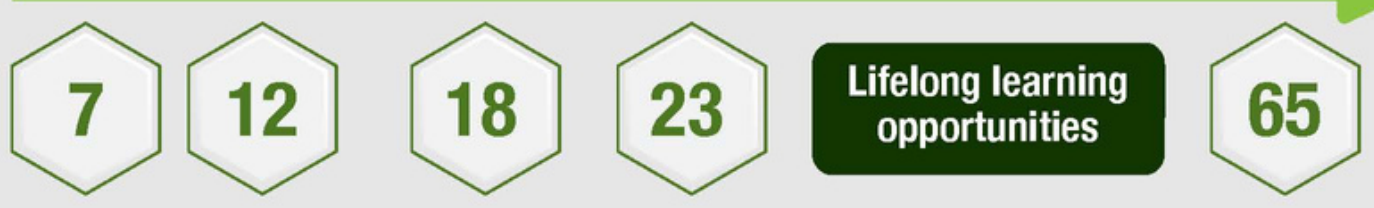




\section{contents}

\section{Society News}
4
7

\begin{abstract}
Guest Editorial - Mark Burnett
Executive Manager's Corner

The Professional (Affairs) Corner
\end{abstract}

\section{University News}

$\begin{array}{ll}12 & \text { Stellenbosch University } \\ 14 & \text { Wits School of Geosciences }\end{array}$

\section{Articles}

16 Geological travels in Nepal

34 Geoheritage report

\section{Book review}

\section{Going to Ground, Nick Norman}

\section{Mineral Scene}

36 Transvaal Jade / Grossular garnet

\section{Obituaries}

39 Christian Roering

\section{The Geotraveller}

46 Geology and Antiquities of Malta and Gozo

\section{Other Business}

$\begin{array}{ll}59 & \text { GSSA student awards } \\ 59 & \text { MINSA activity } \\ 60 & \text { GSSA Events } 2021 \\ 61 & \text { REI Fund is inviting applications } \\ 62 & \text { Classifieds } \\ & \end{array}$

\section{Geological Society of South Africa}

\section{Front Cover:}

Nilgiri South (6839 m ASL), in the Annapurna Range, viewed from Tatopani. See article on page 16 .

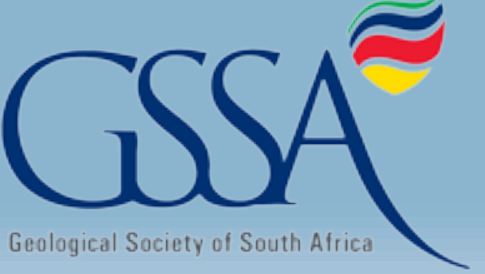

GSSA

MANDELA MINING PRECINCT (FORMERLY CSIR MININGTEK), CORNER RUSTENBURG \& CARLOW ROADS, MELVILLE, SOUTH AFRICA.

P.O. Box 91230

Auckland Park 2006

Johannesburg, South Africa

Tel: +27 113580028

e-mail: info@gssa.org.za

Web: www.gssa.org.za

\section{COMMITTEE}

Convener \& Editor: Trishya Owen-Smith .......... 0115592677 Advertising: $\quad$ GSSA Office ................. info@gssa.org.za Design \& Layout: $\quad$ Belinda Boyes-Varley ........ 0791297748 Printing: $\quad$ Seriti Printing (Pty) Ltd ..... 0128437632

All submissions to: Trishya Owen-Smith geobulletin@gssa.org.za

Attach Word .doc + individual high resolution .jpg's for images

Contributions for the next issue should be submitted by: $14^{\text {th }}$ February, 2021.

Geobulletin is provided free to members of the GSSA. Nonmember subscriptions per four issue volume are R350.00 for South Africa. Overseas and rest of Africa, R350 plus postage. Surface mail, R200.00. Airmail, R300.00. The views expressed in this magazine are not necessarily those of the GSSA, its editor or the publishers.

ADVERTISING RATES (Excl. VAT \& Agency Commission): Geobulletin is published by the Geological Society of South Africa (GSSA) and appears quarterly during March, June, September and December each year.

2021 RATES: info@gssa.org.za

For detailed prices, mechanical and digital submission requirements, please contact the GSSA Office, info@gssa.org. za, to obtain an up-to-date Rates Card or other information.

DEADLINES FOR COPY AND ADVERTISING MATERIAL are: $15^{\text {th }}$ February (March issue)

$15^{\text {th }}$ May (June issue)

$14^{\text {th }}$ August (September issue)

$15^{\text {th }}$ November (December issue)

Please note that the design and layout of adverts and inserts is entirely the responsibility of the advertiser. If you wish to contract the services of the GB graphics and layout supplier for this service, please contact Belinda Boyes-Varley directly, well in advance of the advert submission deadline to make arrangements.

Geobulletin $\odot 2020$ The Geological Society of South Africa. All rights reserved. Geobulletin is available as gratis open access. Issues may be downloaded from the Geobulletin Archive:

https://doi.org/10.25131/geobulletin ISSN 0256-3029 


\section{guest editorial}

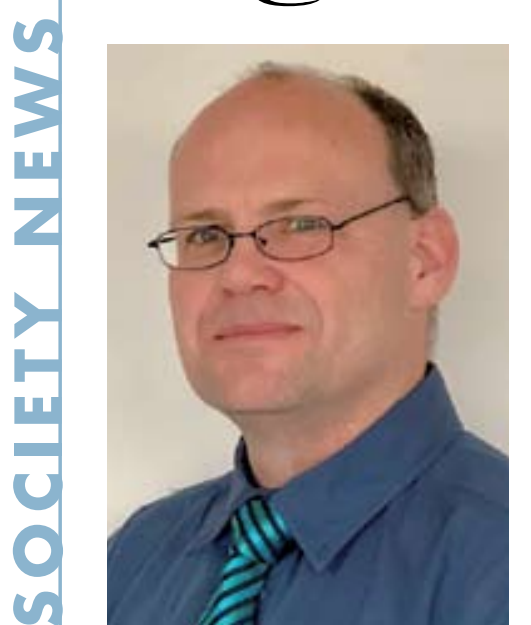

What does the "New Normal" mean for Geologists and Earth Scientists?

"COVID-19 has altered many things, but it does not alter geology or define the frontier of operational efficiency in each commodity sector. Besides demand, these are the two most critical factors for identifying marginal sources of long run supply."-McKay

The current Covid-19 pandemic has raised a number of interesting questions as to what the 'new normal' will be for the metals and mineral industry in both the medium term and long term. As Saenz et al. ${ }^{2}$ noted in June, "We cannot afford to go back to the old way of doing things. The companies that most aggressively adapt and extend new ways of operating will turn this crisis to their advantage".

If the mining industry responds to the pandemic in the manner that other industries have already responded, geologists will need to adapt as well, by changing the way that we work, but also acquiring additional skills in order to remain relevant and marketable in a world that will be defined by increasing levels of digitisation and automation. However, neither of these can be seen in isolation. "Long-term success will depend not on automating a list of tasks, but on redesigning the work and processes with an eye toward automation and digitalization where they will provide the greatest value". 2

We are all now familiar with online conferencing and meetings, so the concept of managing a project remotely or undertaking site visits by proxy is no longer one that is immediately rejected with derision; the reality is that virtual site visits are becoming by far the 'new normal'. During the recent GSSA conference on Project Management, Graham Duncan from Minrom presented on the "Principles of Remote Project Management". The application of this methodology has now become a reality for consultants, given that some of my colleagues have changed time zones (in a virtual manner), so that they could undertake site visits in South America while remaining in Australia. In a similar manner, universities in the United Kingdom, e.g. Aberdeen ${ }^{3}$ and Royal School of Mines ${ }^{4}$, are actively advertising that their students are now participating in virtual field trips as a necessary part of their education and training. Does this give the same "hands on experience"? Obviously not, but the economic reality is that mining and exploration must continue, as most countries consider mining an essential component of their economies, ${ }^{5}$ both for revenue generation as well as for employment. Having a domestic supply of raw materials reduces your exposure to geopolitical risk and supply-chain fragility; it might not, however, prevent you from being exposed to domestic stressors.

One of the less obvious trends that has been observed during the current pandemic is the ever-increasing reliance of governments on mining operations to provide not only revenue in the form of taxation and royalties, but also necessary social and infrastructural services in rural areas. Again, this is not a new phenomenon, being well known to anyone who has operated or worked on a mine in a remote area of the world; however, the pandemic has increased the pressure on mines to provide these necessary services.

This trend, however, clashes with the industry desire to automate as much as possible-both to reduce costs and increase efficiency, but also to minimise (and where possible, remove) the human component from the mining value chain and in so doing reduce the risk of accidents and fatalities. In a similar manner, having an expensive expat employee having to isolate for 14 days on return from their off-cycle makes no sense from an economic point of view (this is on the assumption that the current status quo holds true).

An example of a fully automated mine is Resolute Mining's Syama operation in Mali, with Australian operators trialling remote operations from offices in Perth. However, the drive to a fully automated supply chain does not end 
on the mine; if the Covid pandemic had not occurred, Kongsberg's YARA Birkeland, the world's first fully electric and autonomous container ship, with zero emissions, was due to commence operation this year. ${ }^{6}$

The removal of people from the supply chain has some notable benefits when you take into account that the cost of both air and sea freight has risen sharply due to the cancellation of flights and cargo ships being forced to take the longer shipping route via the Cape of Good Hope, both of which lead to uncertainty in the supply chain and in turn result in price volatility.

Due to the fact that we are seeing a global reduction in demand for transport, we have also seen the downstream economic impact of this, inter alia, in the aircraft manufacturing industry - a large consumer of specialty metals and minerals such as aluminium, beryllium, graphite, vanadium and titanium. As with the prior trends that have been noted, the seeds of the changes were already present-Airbus had already decided to cease production of the $A 380$ in 2019, with the last aircraft being delivered in 20217; while Boeing has announced that the last 747 will be produced in $2022 .{ }^{8}$

World economies are now reviewing supply chain robustness, a topic that had already been under discussion. As Saenz et al. ${ }^{2}$ report, "supply chain leaders were beginning to see the limitations of these cost-efficient but brittle supply chains in the face of increasingly frequent disruptions, including natural disasters, escalating trade barriers, demand shocks and labor strikes. The scramble to reestablish supply chains during the pandemic further underscored the limitations of inflexible, opaque supply chains".

Given the current instability and uncertainty of the supply of raw minerals and metals, is it surprising that China was instrumental in creating the Regional Comprehensive Economic Partnership, a free trade agreement between the ten ASEAN nations and their five major trading partners, excluding the USA? $?^{9,10}$

So, what are the potential implications of weak supply chains and further changes in global economics? If we consider the case of bulk commodities, most suppliers enter into long-term offtake agreements with manufacturers; however, Ramanathan"1 noted that "The outlook for consumer behaviour and purchasing trends is also fraught with uncertainty, particularly with the pandemic causing heavy job losses in multiple sectors... buyers are seeking flexibility and optionality rather than discounts" and "producers are looking to limit discounts in the contracts, to offset the potential hit from the supply flexibility clause-particularly given that many are facing narrow margins when taking production costs into consideration".

With most countries facing the economic repercussions of excessive deficit spending during the pandemic, it is a certainty that governments will be unable to resist the tendency to levy additional taxes on the mining and beneficiation industries. However, this may not have the results that are anticipated, a salutary tale being that of Indonesia, where a ban on the export of nickel concentrate, unless beneficiated, resulted in China sourcing the required raw material from the Philippines, Australia and New Caledonia.

So where does all this leave the geologist? If I may be so bold, I will hazard a few guesses:

- There will be ongoing pressure for geologists and earth science professionals to become increasingly tech savvy and multi skilled.

- Mining operations (and by default exploration activities) will try and reduce their human footprint, either by automation or remote working practices.

- There will be fewer jobs-whether they will be better paid is a moot point

- Understanding the total supply chain will become important, as will be the economics of geology (i.e. mineral economics), not just economic geology.

\section{Mark Burnett}

Mark is a consulting geologist, writing in his personal capacity. This editorial is a precursor to a future contribution on the current status of the mining industry and the impact of the Covid-19 pandemicwatch this space.

Further reading and resources:

1. McKay, H. (2020). BHP's economic and commodity outlook (FY20 full year). Available online at: https://www.bhp.com/media-and-insights/ 
prospects/2020/08/bhps-economic-and-commodityoutlook/.

2. Saenz, H., Anderson, N., Ledingham, D. and Supko., M. (2020). The "New Normal" Is a Myth. The Future Won't Be Normal at All. Bain and Company Briefs. Available online at:

https://www.bain.com/insights/the-new-normal-isa-myth-the-future-wont-be-normal-at-all/.

3. University of Aberdeen (2020). Available online at: https://www.linkedin.com/posts/university-ofaberdeen_due-to-covid-19-restrictions-this-yearsactivity-6727874219830468608-IXqB.

4. Mason, P. (2020). The first RSM Virtual Field Geology course in SE Spain. Available online at: https://www. linkedin.com/posts/department-of-earth-scienceand-engineering-imperi_geologyrocks-activity6733069464792838144-0h2-.

5. Jowitt, S.M. (2020). Covid-19 and the global mining industry, SEG Discovery, no 122, pp 33-41. Available online at:

https://www.researchgate.net/

publication/343021520_COVID-19_and_the_Global_ Mining_Industry.

6. Kongsberg (undated). Autonomous ship project, Key Facts about Yara Birkeland, Available online at: https://www.kongsberg.com/maritime/support/ themes/autonomous-ship-project-key-facts-aboutyara-birkeland/.

7. Schwartz, M.S. (2019). Airbus To Stop Production Of A380 Superjumbo Jet, Available online at: https://www.npr.org/2019/02/14/694620105/

airbus-to-stop-production-of-a380-superjumbojet? $\mathrm{t}=1605536665240$.

8. Hemmerdinger, J. (2020), Boeing slashes output, delays 777X to 2022 and confirms end for 747.

Available online at:

https://www.flightglobal.com/airframers/boeingslashes-output-delays-777x-to-2022-and-confirmsend-for-747/139534.article.

9. BBC (2020). RCEP: Asia-Pacific countries form world's largest trading bloc. Available online at:

https://www.bbc.co.uk/news/world-asia-54949260.

10. Wong, C. (2020). 15 Asian nations sign RCEP, world's biggest free-trade deal, after eight years. Available online at:

https://www.scmp.com/news/china/diplomacy/ article/3109939/china-declares-victory-15-asiannations-sign-worlds-biggest.

11. Ramanathan, A. (2020). Pandemic Delays Start of Some Minor Metals Contract Negotiations. Available online at:

https://www.iene.eu/pandemic-delays-start-ofsome-minor-metals-contract-negotiations-p5898. html.

12. AMC (2020). Geology 4.0: The final bow? Available online at:

https://www.youtube.comwatch?v=tCx7uAKLKR8\&t $=2 \mathrm{~s}$

\section{executive manager's}

2020 has been a challenging and chaotic year globally as far as public health, economic growth, natural disasters, and political stability are concerned. On the plus side we have not seen as many catastrophic seismic events, or seriously disruptive volcanism as has been the case in some prior years - at least as of the time of writing. Cape Town has, however, experienced minor seismic events in the last quarter, the first of which was the day after a major event of magnitude 6 occurred on the Indian Ocean ridge $1600 \mathrm{~km}$ south of Cape Town. There are different schools of thought about the triggers for

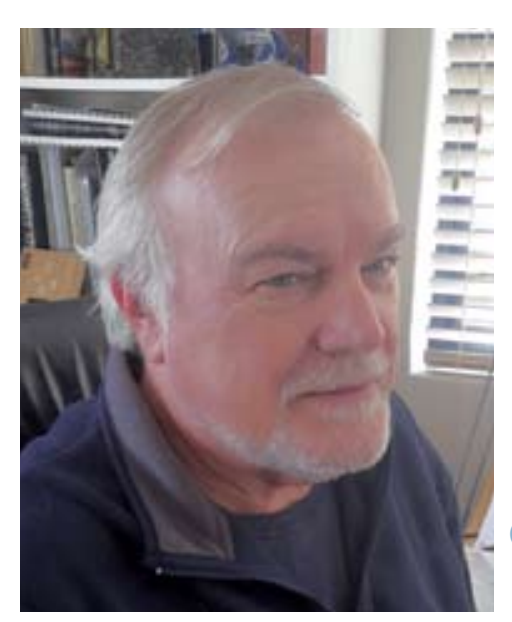
1

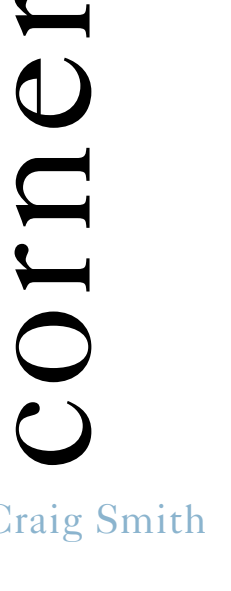


these types of events. The 'mainstream thinking' of the majority of earth scientists is that the earthquakes are not related. Another view is that the events are related insofar as the Cape Town shaking is a far-field plate adjustment response to the ridge event. I have the sense that fewer earth scientists believe this-but some of those who do are recognised experts. There have been major earthquakes in the Cape in historical times; town planners and disaster relief authorities need to be mindful of this. There may be a need for improved seismic monitoring in the area.

The Covid-19 crisis has been with us for most of the year, the consequent lockdowns affecting everyone to lesser or greater degrees. The GSSA and many other organisations have fuelled a 'Zoom Boom' in response, and this has been generally very successful. The GSSA transitioned early to online formats thanks largely to Noleen Pauls and the Meetings Committee. In addition to keeping the original event schedule for the most part, a series of free lunchtime lectures was organised and these were very well attended. In short, online events are easier to attend, and less costly to stage because there are no venue costs (allowing much lower registration fees for paid events). Global participation by both speakers and delegates is possible; there has been participation from every continent except Antarctica. Most of the lectures are lodged on the GSSA You Tube channel (with speaker permission). A downside of remote conferencing is the lack of face-toface networking opportunities, particularly important for young professionals who are trying to build careers. Networking is an integral part of career growth, and while software solutions are being marketed, we have yet to see an application as good as face-to-face contact. Nevertheless, it is clear that digital events are the future, possibly combined with a contact component. The availability of effective vaccines in 2021 will not change this.

Mentoring is another activity that is traditionally done face-to-face, and it is feared that our students and young professionals have fewer opportunities because of the pandemic. The GSSA is engaged in a pilot program organised by SACNASP and Tania Marshall (VP Professional Affairs), which has been successful to this point. It is likely this will be expanded in 2021.

Given the 'new normal', is it an opportune time to assess whether undergraduate geology programs in South Africa and elsewhere are imparting the right skills to students? This was an issue before the pandemic, but which is now elevated in importance. There is no question that South African graduates are world class in the technical aspects of earth science, but should they be doing a bit more outside of classical geology? Project management, data management and coding, to name just a few skill sets, are increasingly important in industry and research careers. The GSSA will continue to organise events dealing with some of these topics. There is clear demand from young professionals.

In addition to these issues, personal and professional ethics have taken on added importance during a tumultuous 2020, perhaps best demonstrated by election politics in the United States. Ethics was an early casualty in that journey, and it will take more than a change at the helm to turn that particular ship around. Invented 'news' and propaganda spread by social media are a part of the problem, and it is apparent that many news outlets and legal professionals are not always aligned with reasonable ethical standards. The lesson for South African professionals should be clear; ethics and standards of behaviour need to be adhered to. Ethics is the backbone of civil society, as well as personal and professional behaviour.

As we wind down to the end of the year, please stay safe. Many of us are not doing much travelling yet, and I suspect holiday destinations may be a bit subdued this year, so enjoy the hopefully more relaxed year-end period. The GSSA offices will close from December $16^{\text {th }}$ and re-open on January $4^{\text {th }}$. The email traffic will be monitored during this period. May 2021 bring an end to the pandemic, and a renewal of growth and prosperity.

\section{Craig Smith}




\section{Be the mentor}

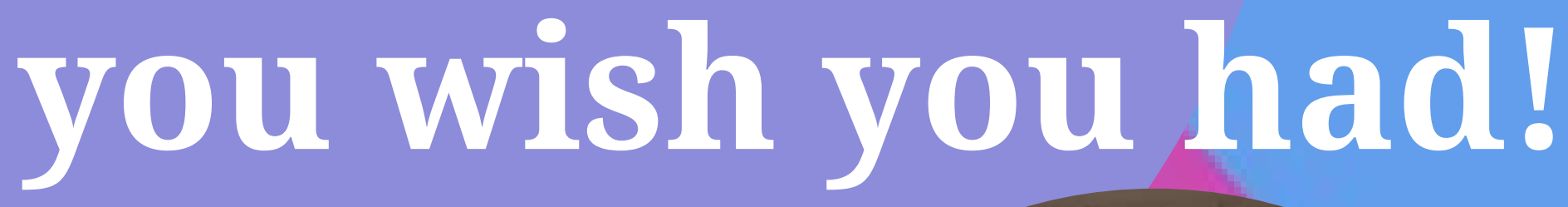

Bridge the Gap Geosciences Guidance Program (BTG), is a student run organization that focuses on mentorship between undergraduate and postgraduate students as well as students and industry professionals. In addition BTG hosts a number of informative talks, workshops and field trips to expose students and graduates to opportunities and expectations in the work environment.

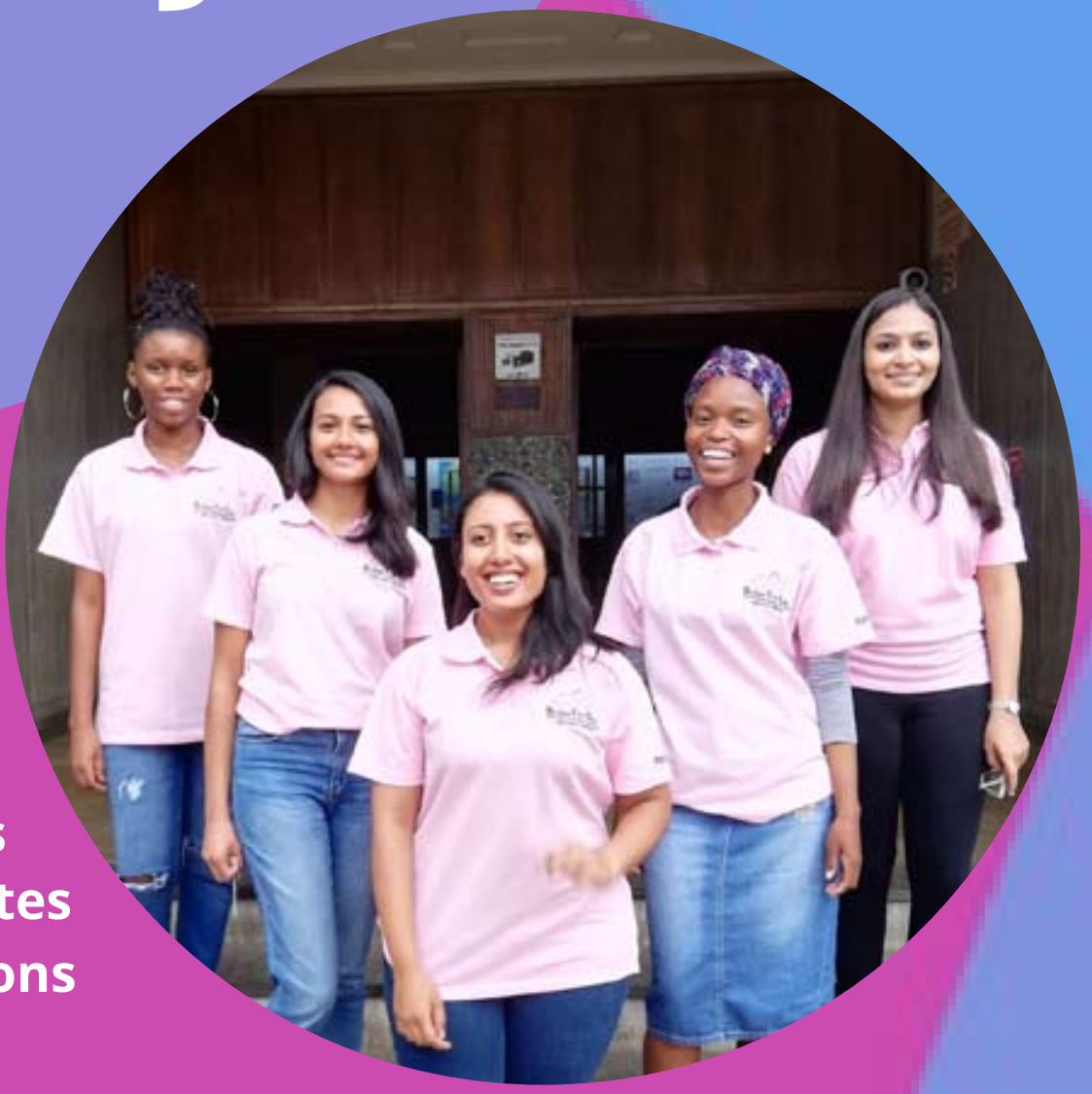

Earn CPD points through mentoring! Be the mentor you wish you had and assist in giving some guidance to geology undergraduate and postgraduate students by signing up to be a mentor through BTG. We invite all geosciences/ mining related companies, industry

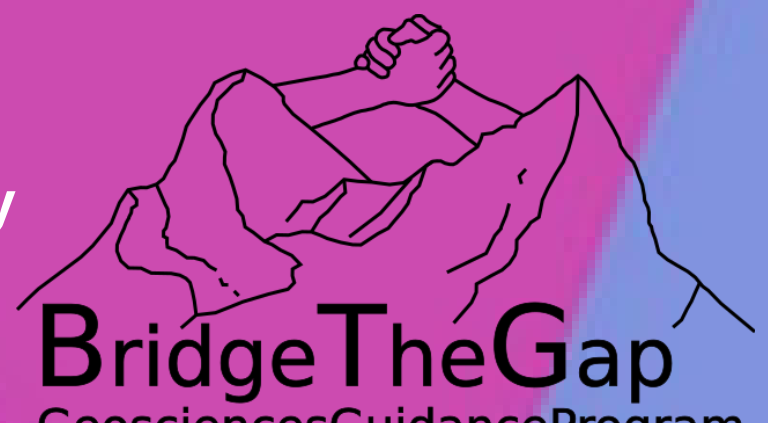

GeosciencesGuidanceProgram EMPOWER || INSPIRE professionals and academics to 'bridge the gap' between university and industry, and to act as positive role models by joining the BTG program as a mentor, sponsor or motivational speaker.

If you are interested in getting involved please complete the Google form by clicking on the following link: https://forms.gle/Sf5tMciuSStAQuFL8

Your influence can go a long way in encouraging and shaping aspiring geologists to become future leaders. We believe that each of us can inspire and empower students by being 'the mentor you wish you had' 


\section{who is the GSSA?}

Who is the GSSA?

- Membership

- Fellows Committee

- Branches \& Divisions

The Geological Society of South Africa (GSSA) is a not-forprofit Scientific and Professional Society for earth scientists first established in 1895. Our objective is to promote and advance the earth sciences, including the study of the earth sciences, the associated public interests in the earth sciences, the earth sciences professions and the interests of the practitioners of the earth sciences, and to encourage and uphold the highest professional and ethical standards among our members.

As of November 2020, the GSSA has eight portfolio committees, each headed by a Vice President. These are:

- Finance (Mr Thomas Molelengoane)

- Meetings \& Directorate of Professional Programmes (Ms Noleen Pauls)

- Networking (Dr George Henry)

- Academic Affairs \& SAJG (Prof. Steve McCourt)

- Membership \& Transformation (Mr Dumi Sibaya)

- Branches \& Divisions (Mr Gordon Chunnett)

- Fellows Committee (Prof. Judith Kinnaird)

- Professional Affairs (Dr Tania Marshall)

This month we will look at the roles and responsibilities of the Membership \& Transformation, Fellows Committee and Branches \& Divisions portfolios.

\section{Fellows Committee}

The Committee annually undertakes a range of duties. It provides support to the ManCo team. It also co-ordinates the du Toit lecture series and provides support for other specialist groups when requested. A big feature of the year is the Fellows Dinner, at which new Fellows are inaugurated and old Fellows meet to exchange news and views in a once-a-year opportunity that is not to be missed. I will be taking over as MC at the next event, and
THE

DROFESSIONAL (AFFAIRS) CORNER

everyone will miss Gordon's jokes I am sure. Thanks to Gordon for all his efforts over the last 10 years.

The Fellows Committee also manages and adjudicates the GSSA Awards Program. However, assistance is sought from academic colleagues who are not on the Fellows Committee and we are thankful to them for their help and advice.

For members, the awards recommended by the Fellows Committee are:

- The Draper Memorial Medal - This is the highest scientific award of the GSSA. It was instituted in 1932 in Honour of Dr David Draper, one of the founding Fathers of the Geological Society in 1895. The award is made annually as a tribute to an exceptional contribution to the advancement of South African geology.

- The Des Pretorius Memorial Award - This was introduced by the GSSA in 1998 in memory and recognition of the pioneering work of the late Prof. Des Pretorius. The award is made for an exceptional contribution in the field of Economic Geology in Africa. The award was not made until 2004.

Usually the awards are announced at the November Fellows Dinner, but the dinner was cancelled this year due to the Covid-19 pandemic. These awards and the conferring of new Fellows will be announced by the end 
of the year and hopefully the awards and fellowships will be presented at the next Fellows Dinner.

For student members the awards are:

- The John Handley Award - This was introduced in 2002/2003 to recognise the best MSc thesis awarded at a South African University in the year prior to the year in which submissions are adjudicated.

- The Corstorphine Medal - This is for an outstanding MSc thesis of high international standard.

- The Haughton Award - This is made annually to recognise the best BSc Honours thesis awarded at a South African University in the year prior to the award.

- The SACNASP Award - This is for the best fourth year student in Earth Sciences.

Normally winners are announced at the mid-year AGM. However, because of the Covid-19 pandemic, this year the AGM was a virtual event, and no awards were announced, although the prize-winners have been notified. The list of student awardees is given on pg. 59 of this issue. A suitable time and venue for presenting the awards to the recipients will be announced when it can be organised safely.

Prof. Judith Kinnaird has recently retired as Director of

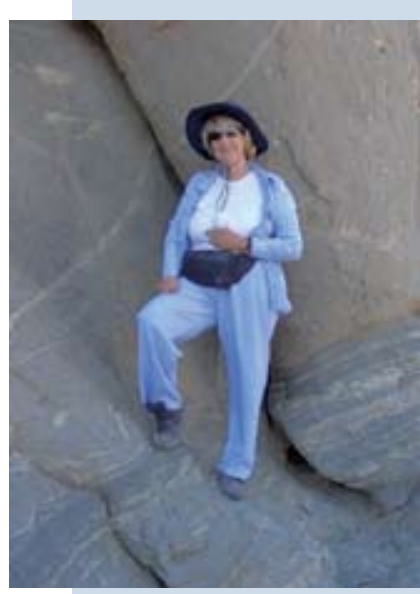
the Economic Geology Research Institute at the University of the Witwatersrand, Johannesburg, but remains as co-director of the Centre of Excellence for Integrated Mineral and Energy Resource Analysis (CIMERA), funded by the DSI/NRF.

She has an Honours BSC degree from the University of London and an MSc and $\mathrm{PhD}$ from the University of St. Andrews in Scotland. She has worked on tin-bearing granites in Nigeria and South Africa, Li-Be-Sn-Nb-Ta- and gembearing pegmatites in Namibia, Nigeria and Somaliland, and uraniferous deposits in Namibia, South Africa and Malawi. At the University of the Witwatersrand she leads research on the northern limb of the Bushveld Complex and currently contributes to teaching of the MSc in Economic Geology.

\section{Membership and Transformation}

The GSSA was established in 1895 , and it takes a lot to survive for so many years (125 years). Without a doubt, the members and their contributions have kept this organisation going over the years. Together with the office staff, the Membership Portfolio manages membership movements and assessment of new applicants.

The GSSA has the following membership categories:

- Member* - Practising earth scientists who have obtained an accredited Honours or equivalent degree in a relevant geological or earth science field

- Fellow* - Members who have been engaged in a responsible earth science profession for at least five years

- $\quad$ Student - Persons registered as full-time students at a higher learning institution

- Affiliate - Members of the public with an interest in the earth/geological sciences

- Junior-Scholars

- Institutional - Companies and organisations associated with, or involved in, the earth sciences or mineral and energy resources or other sectors

- Other - We also have other subcategories that cater for retired, dual status for spouses, honorary and lifelong membership. If you have an interest in earth sciences, there is room to be part of this organisation and to contribute to its goals in many other aspects to enhance the GSSA.

* Only members in these categories may use their GSSA membership to sign off on SAMCODE-compliant Public Reports, provided they have the relevant experience as defined in the applicable Code.

Approximately $10-15 \%$ are international members $(10 \%$ from the rest of Africa and another 5\% from further afield). It is estimated that $60-70 \%$ of working earth/ geoscientists are members of the GSSA, of which some $80 \%$ are employed within the mining industry. A further 1205 GSSA members are also registered with SACNASP.

As of 2020 , the GSSA has 2700 members, of which 100 are student members. This is a decrease of $10 \%$ since 2018 . 


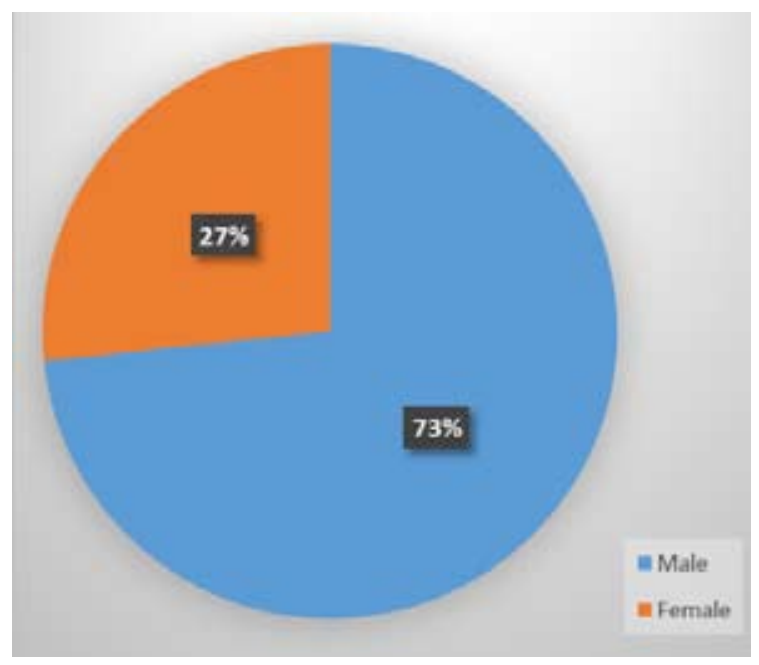

It is thought that the increasingly difficult economic situation, exacerbated in no small measure by the Covid-19 pandemic, along with high unemployment levels among post-graduate geoscientists, particularly, have left many unable to keep up their GSSA memberships, in favour of SACNASP registration. It must be noted, however, that the GSSA does allow members to "suspend" their membership during difficult circumstances and simply pick up again when they are able to pay their fees.

A recent survey in respect of the effects of the pandemic indicated that, whereas a significant proportion of our members are industry-based geologists, our membership covers the full range of the geosciences.

The landscape in the modern world is rapidly changing, demanding that we continually assess our relevance

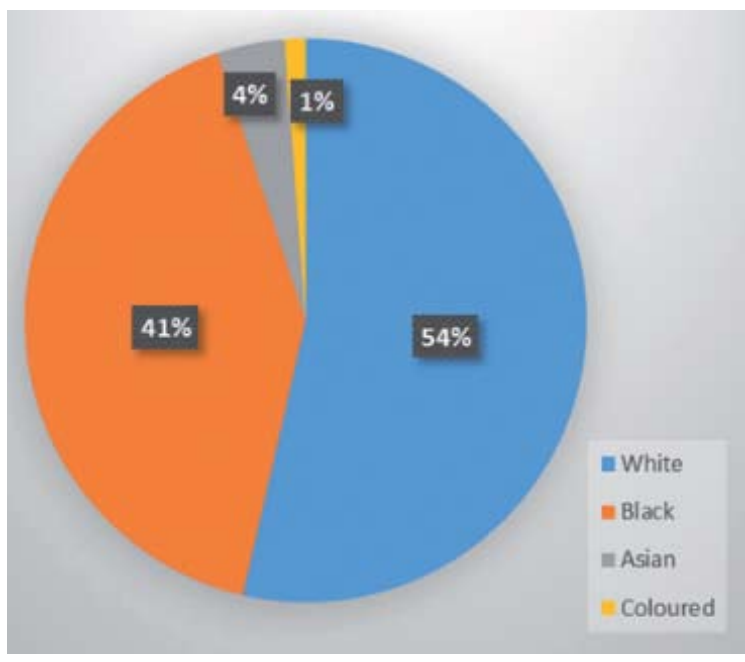

and adapt to the new terrain. In the last decade membership increased by almost $20 \%$, which peaked in 2016, but since then there have been signs of slow-down. We have come from a much lower base to increase our female membership to $28 \%$. Our young members $(<40$ years) form about $67 \%$ of our membership. Recently, we conducted membership surveys and surprisingly more than $60 \%$ of the responses were from the age above 40 years. This is in sharp contrast with our membership profile.

The two surveys conducted in June and October this year showed that the Covid-19 pandemic has had a major impact on work practices, with members increasingly working from home. This is shown to be related to salary reductions and research programs/ projects that have been impacted.

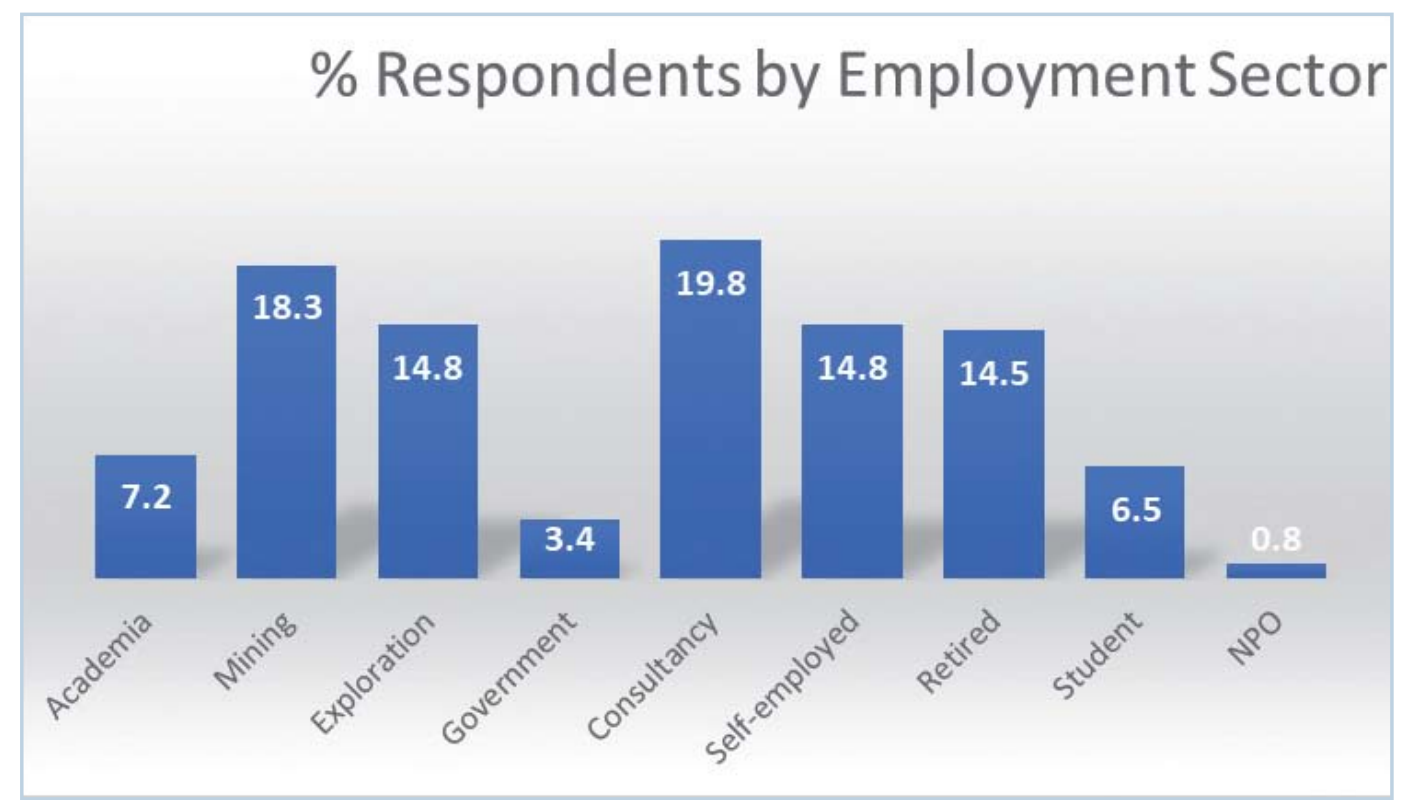



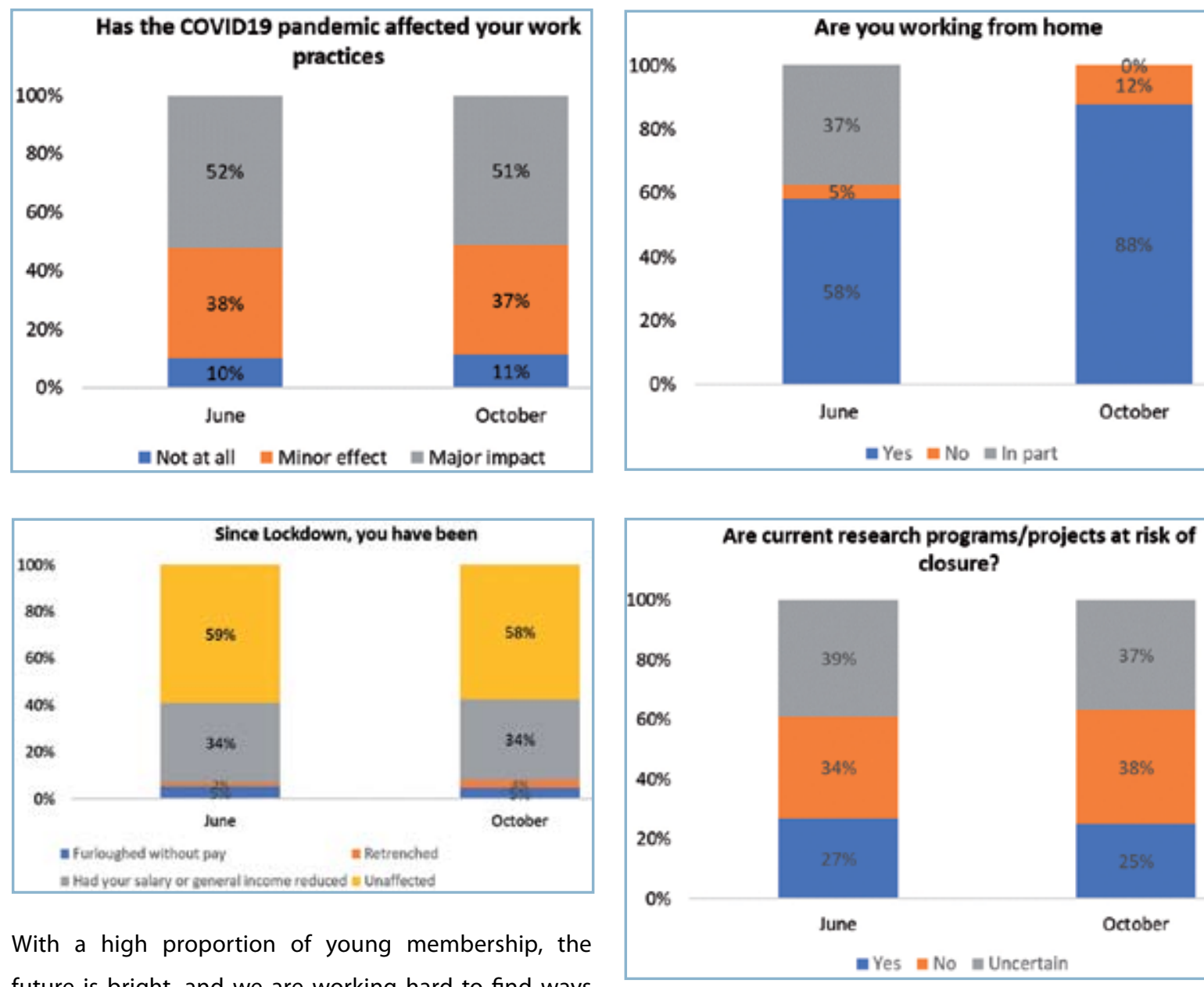

With a high proportion of young membership, the future is bright, and we are working hard to find ways for meaningful engagement. In association with the Professional Affairs portfolio and SACNASP, a mentorship program was launched recently as part of giving a with the Meetings \& DPP and Branches \& Divisions portfolios, we encourage our members, as well as the general public, to increase their interest and knowledge platform for our emerging geologists. In co-operation in earth and geological sciences.

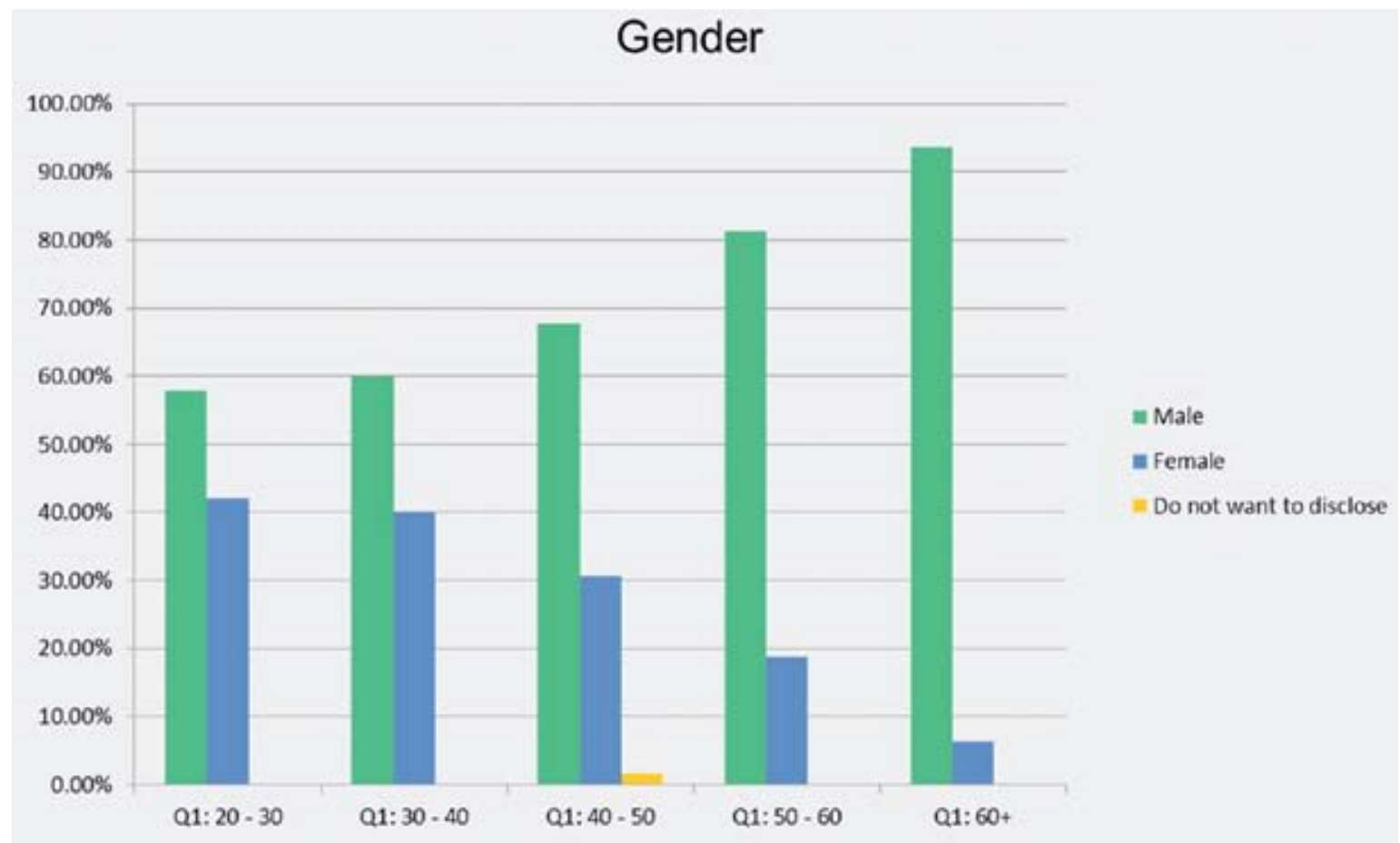


Dumi Sibiya is a Geologist currently employed by Tronox, with more than 20 years of experience in the mining industry, having worked in various roles in mining projects and production geology in different parts of the world. A large portion of his working career has been spent in mineral sands, with some exposure in base metals and iron ore. Dumi is a Fellow of the GSSA and VP of Membership \& Transformation.

\section{Branches and Divisions}

The Geological Society has members scattered across the country, and some outside of our country borders. Additionally, the membership spans a range of earth science disciplines and employment sectors. Over our 125-year history, members have formed local branches and specialist divisions that fulfil meeting and discussion group needs of those communities. This includes academic and economic interests, and many other valid reasons geoscientists find to get together, including some QA/QC on beer, etc.

The success of a branch is largely dependent on its leadership committee, and some prominent leaders have made the difference by being long-standing and active proponents of the branch activities. The GSSA Constitution makes specific provision for the formation and administration of Branches and Divisions, which includes the need for branches to report to the Society on their activities, funding and any information that allows the Society to provide an annual audit of the financial health of any Branch or Division. Ordinarily, each branch maintains its own books and bank accounts, but where assistance is needed the Centre can and does step in to provide guidance and structure to a struggling branch.

While it is not a requirement, it is recommended that membership of a branch or division be in parallel with and in addition to membership of the GSSA as a whole. It is important to note that professional status is conveyed by membership in the 'mother society', and not by the branches or divisions alone.
A listing of current Branches is as follows:

- The Egoli Branch (Gauteng based) can be contacted by emailing egoli@gssa.org.za

- The Bushveld Branch (Rustenburg based) can be contacted by emailing Johan Marais at johan. marais5@sibanyestillwater.com.

- The Barberton Branch (Mpumalanga based) can be contacted by emailing chrisr@bmines.co.za

- The Western Cape Branch (WCB) can be contacted by emailing admin.wcb@gssa.org.za and by viewing their fabulous website on https://www.gssawc.org. za. The WCB has a very active Geoheritage subbranch/group headed by Dr Cameron Penn-Clarke, who can be contacted by emailing cpennclarke@ gmail.com

- The Northern Cape Branch, which has recently regained life, can be contacted through Joshua Kilani by emailing Joshua@res.co.za.

- The KZN Branch is headed by Riaan Botes and can be contacted by emailing debbioe.abel@durban.gov.za.

- The Eastern Bushveld Branch, formed from the Steelpoort, Limpopo and OFS Branches, is currently inactive, awaiting a fresh "push". Persons interested in championing these causes are welcome to contact Gordon Chunnet at info@gssa.org.za.

- While not branches of the GSSA, the Overberg Geoscientists Group and the Eastern Cape Group are very active associated Interest Groups.

Several student branches are flourishing and serve as a valuable feeder zone for the Society as a whole:

- Venda Branch

- Fort Hare Branch

A "Specialist Division" can be established to consolidate and service the needs of specific interest groups. Three currently active Divisions are the Groundwater Division (GWD), the Mineralogical Society of South Africa (MINSA) and the Geoheritage Division.

The same services and needs for financial accountability as with Branches apply to Divisions, and audit services provided by the Centre can and are used to cover the health status of financial matters, where they do not 
conduct their own internal audits. The results of audits are then consolidated for the GSSA Annual Report.

\section{Current Specialist Divisions are as follows:}

- The Groundwater Division is chaired by Fanus Fourie, who can be contacted by emailing membership@ gwd.org.za.

- The Mineralogical Association of South Africa (MINSA) was established in 1979 to foster interaction within the mineralogical community of South Africa. MINSA organises various events of interest to both professional and amateur mineralogists, geochemists and petrologists and promotes access to cutting-edge developments in the field through free and paid meetings/symposia/workshops, the largest of which was the IMA2014 international conference. MINSA is affiliated with the International Mineralogical Association (IMA). MINSA is chaired by Dr Igor Želiko and can be contacted at minsa@gssa. org.za.

- The Geoheritage Division is chaired by Dr Chris Hatton and can be contacted by emailing Chris Hatton cratonhatton@gmail.com.
- The Tectonics Division and the Sedimentology Division are currently dormant and awaiting new sponsors to "rejuvenate" them. Persons interested in championing these causes are welcome to contact Gordon Chunnett at info@gssa.org.za.

Gordon Chunnett has worked on the Bushveld and other igneous complexes for some 35 years in exploration and mining for Platinum Group Metals. He qualified at Rhodes University and has spent most of his career in the platinum business.

Gordon is currently retired after 31 years with various companies that became Anglo Platinum.

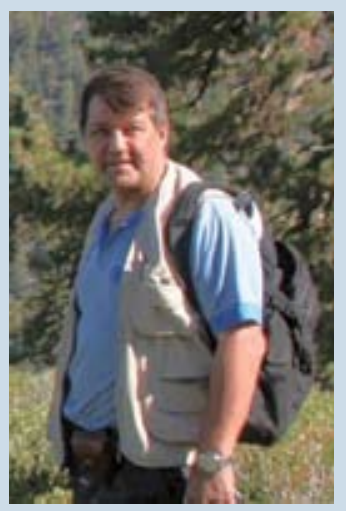
Most recently he was Chair of the Fellows Committee, before taking on Branches \& Divisions, and has a role in the Complaints Committee as Chairman.

Compiled by Tania Marshall with contributions from Dumi Sibaya, Judith Kinnaird and Gordon Chunnett.

\section{all the news fit to print}

STELLENBOSCH UNIVERSITY

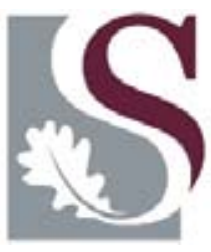

With another, albeit highly abnormal, year almost safely tucked away under the belt, the Department of Earth Sciences at Stellenbosch University is taking the opportunity to reflect on what has just been. Upon such reflection, we are very happy that we were able to weather the tumult of 2020-including the various challenges brought about the Covid-19 pandemic. Indeed, the department, its staff and students certainly rose to these challenges, and we are all very happy (and proud) that we are able to finish the 2020 academic year without compromising the value or standard of our curriculum and the educational opportunities that we provide. In particular, we commend the first term lecturers for mobilising to put their entire curriculum into online format with a lead time of only three weeks; we commend highly our student community for their understanding and active engagement with the curriculum despite the challenges (and teething issues) associated with distance learning; and we thank all our students for making the effort to come back for dedicated on-site interactions for the various practical aspects of their training.

In spite of all of 2020's challenges, there are still a lot of good things that we can report:

\section{A move to continuous assessment approaches}

For a long time, the validity of the traditional examinations approach has been questioned by tertiary educators and educational researchers. In the old examination model, a student's capability in a given subject was 


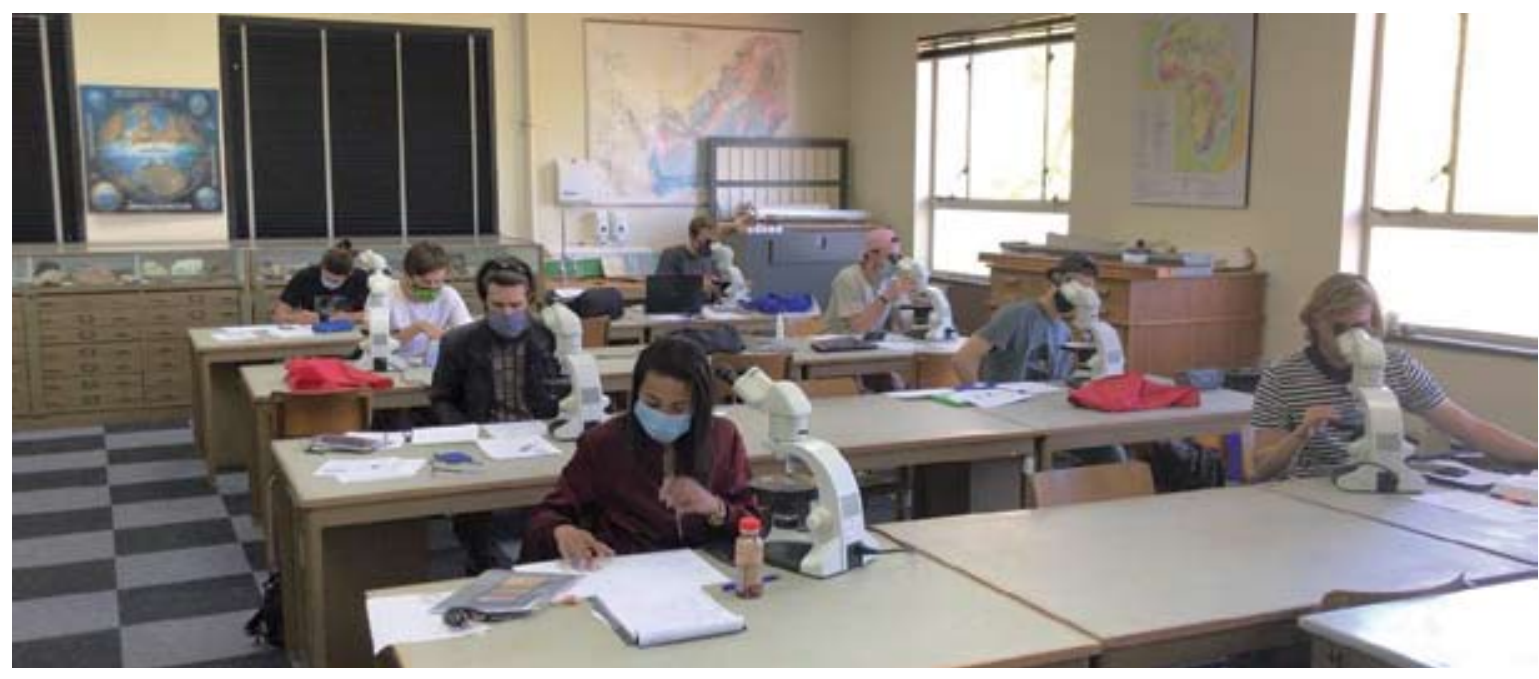

judged largely (60\% of their marks apportioning) by a single three-hour examination sitting. With the changes that were necessitated by the move to online learning, our department has moved wholly to a 'flexible assessment' model. In this model, a student's capabilities are judged more fairly by considering a range of assessment techniques and several assessment opportunities (each counting a smaller proportion of the marks (i.e., $\leq 40 \%$ each). These assessment techniques include traditional tests/exams, written reports, oral presentations, or practical-based activities (e.g., field mapping, geochemical modelling, core logging, etc.). Two advantages of this are: 1) there is a lower risk that students' marks are skewed by having bombed out in a single high-stress exam sitting; and 2) because each assessment is weighted, the student's final mark will reflect the true 'roundedness' of a SU graduate with respect to the theoretical and practical knowledge, and their written and oral communication prowess.

\section{Stellenbosch University software applied to NASA project investigating habitability of Europa}

Open-source thermodynamic modelling software produced by Dr Matthew Mayne and his working group housed between the Earth Science and Computer Science departments (Rcrust) has recently been applied to a study investigating the habitability of Europa, a moon around Jupiter. Matthew presented how he adapted this tool to accommodate problems in planetary sciences at a virtual seminar as part of the Science Visitor and Colloquium programme at the Jet Propulsion Laboratory
Some of our dedicated (Covid-compliant) second year students who came back for practical exposures to optical microscopy and structural geology.

(JPL) of Caltech in the United States of America on the 20th of October 2020. This work in collaboration with Dr Mohit Melwani Daswani from JPL has found evidence to suggest that the ocean underneath Europa's ice sheets could have been formed by metamorphism of Europa's rocky core. This hypothesis, among other work, will be tested when the Europa Clipper mission flies past Europa later this decade. This project has already gained a lot of attention from media with articles in the Daily Maverick in South Africa and the Smithsonian in the USA. For more information on the Rcrust working group and to find out how you can collaborate on aspects of planetary science or metamorphic petrology, contact Matthew at mmayne@sun.ac.za.

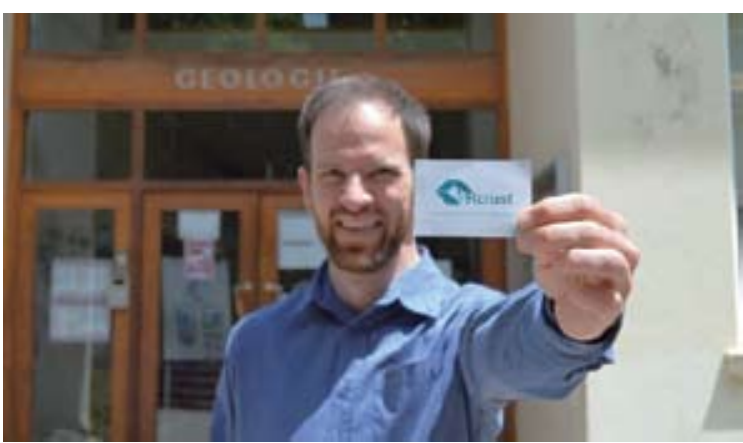

DrMatthew Mayne, creator of Rcrust-a thermodynamic modelling tool that is being applied to a study of Europa, a moon around Jupiter (source: NASA/JPL-Caltech/Univ. of Michigan) 


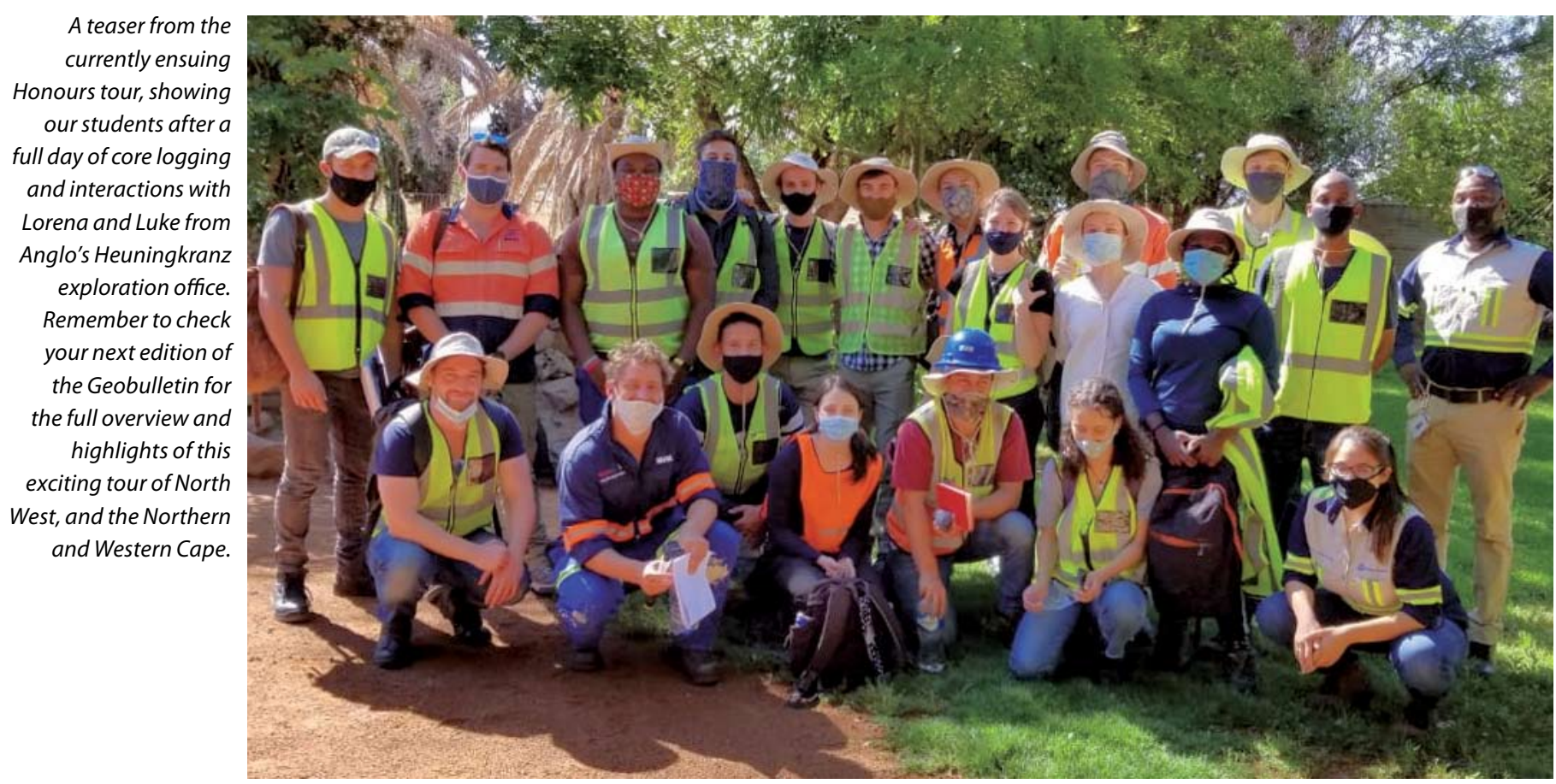

\section{Impacts of climate on humpback whale population recovery}

Prof. Alakendra Roychoudhury has been instrumental in conceptualising and launching the world-class Whales and Climate Research Program. This is a multidisciplinary and multinational research program that seeks to tease out the inter-relationships between climate change and humpback whale distributions (and indeed population recoveries) using observational data from various ocean sectors in the Southern Hemisphere. The program will run over six years and involves environmental geochemists from Prof Roychoudhury's research lab at SU, collaborators at the host Griffith University (Australia), as well as other researchers from UCT, CPUT, Brazil, Ecuador, Panama, and Chile. For more information, please visit www.whalesandclimate.org.

\section{More little geologists and palaeontologists enter the world}

In a last-ditch effort to counteract Prof Roychoudhury's progress with respect to climate change and whales, several other members of staff at SU seem intent on putting more strain on the planet by adding excess population numbers to the world's tally. Seen another way, Dr Bjorn von der Heyden and Dr Ryan Tucker have both done their best to ensure a secure supply chain of future earth scientists. Seen yet another way, both of these two staff can be congratulated and wished much joy and happiness for the new additions to their respective families. Fynn George von der Heyden was welcomed into the world on $7^{\text {th }}$ June 2020; and James Edmund Tucker was equally well received on $24^{\text {th }}$ October 2020. Word on the street is that the supply chain does not end with these two additions and that at least one more is due to follow suit in the first part of 2021.

\section{Bjorn von der Heyden}

\section{WITS SCHOOL OF GEOSCIENCES}

In August the School held a screening of the documentary 'Picture a Scientist', which follows geologist Jane Willenbring, chemist Raychelle

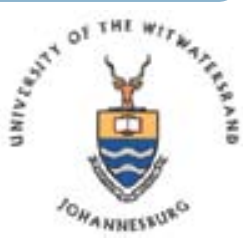
Burks and biologist Nancy Hopkins as they share some of their experiences on being a woman in science. Jane Willenbring (professor ofgeologyat theScripps Institution of Oceanography in California), was kind enough to join us in a special live Q\&A discussion following the screening with many female staff and postgraduate students taking part. Both the screening and the discussion highlighted that while institutions have got some things right, there is certainly scope for improvement for women and other minorities to be more included in science. 


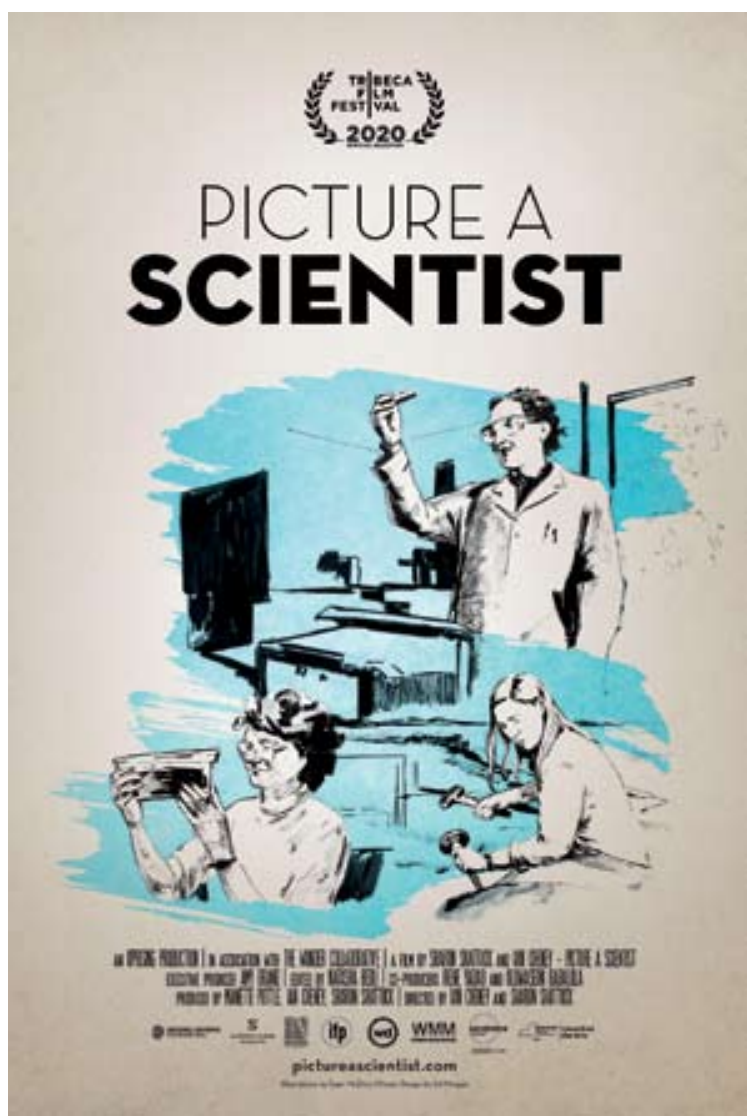

'Picture a Scientist'-an official selection of the 2020 Tribeca Film Festival.

Woman's Month didn't end there-in September Prof. Gillian Drennan was interviewed as the first female Head of School in the history of the School of Geosciences at Wits by Dr Amaleya Goneos-Malka on her podcast 'Womanity-Women in Unity' (if you would like to listen to the interview, please follow this link). And in November-at what would have been the GSSA Fellows Dinner, which has sadly been cancelled-two students from Wits were notified that they had won awards. The John Handley Award for the best MSc thesis at a South African University for 2019, and the Corstorphine bronze Medal for an MSc thesis of outstanding merit and notable international standards, have been awarded to Lechelle Goslin, for her thesis entitled "Deformation and Partial Melting in the Central Zone of the Damara Zone, Namibia". The Haughton Award for the best BSc Honours thesis at a South African University for 2019 went to Bibi Ayesha Jogee for her thesis entitled "Unravelling the Petrogenesis of Mafic Orbicules of the Koperberg Suite and their Metallogenetic Links to Cu Mineralisation". A suitable time and venue for presenting the awards in person is still to be determined, nonetheless the School sends a hearty congratulations to both Lechelle and Ayesha!

Over the past year, the School has also seen $12 \mathrm{MSc}$ and 8 $\mathrm{PhD}$ students submit their theses, and we are very proud of each and every one of them for making the best of such a trying year.

In staff news, Prof. Ray Durrheim (who holds the SARChI Chair in Exploration, Earthquake and Mining Seismology) was asked by the NRF, the Department of Science and Innovation, and the South African International Maritime Institute, to lead a Community of Practice in Upstream Oil and Gas following on from Total's Brulpadda deepwater gas condensate discovery in February 2019. A Community of Practice is commonly used to leverage the expertise of representatives from academia, industry and
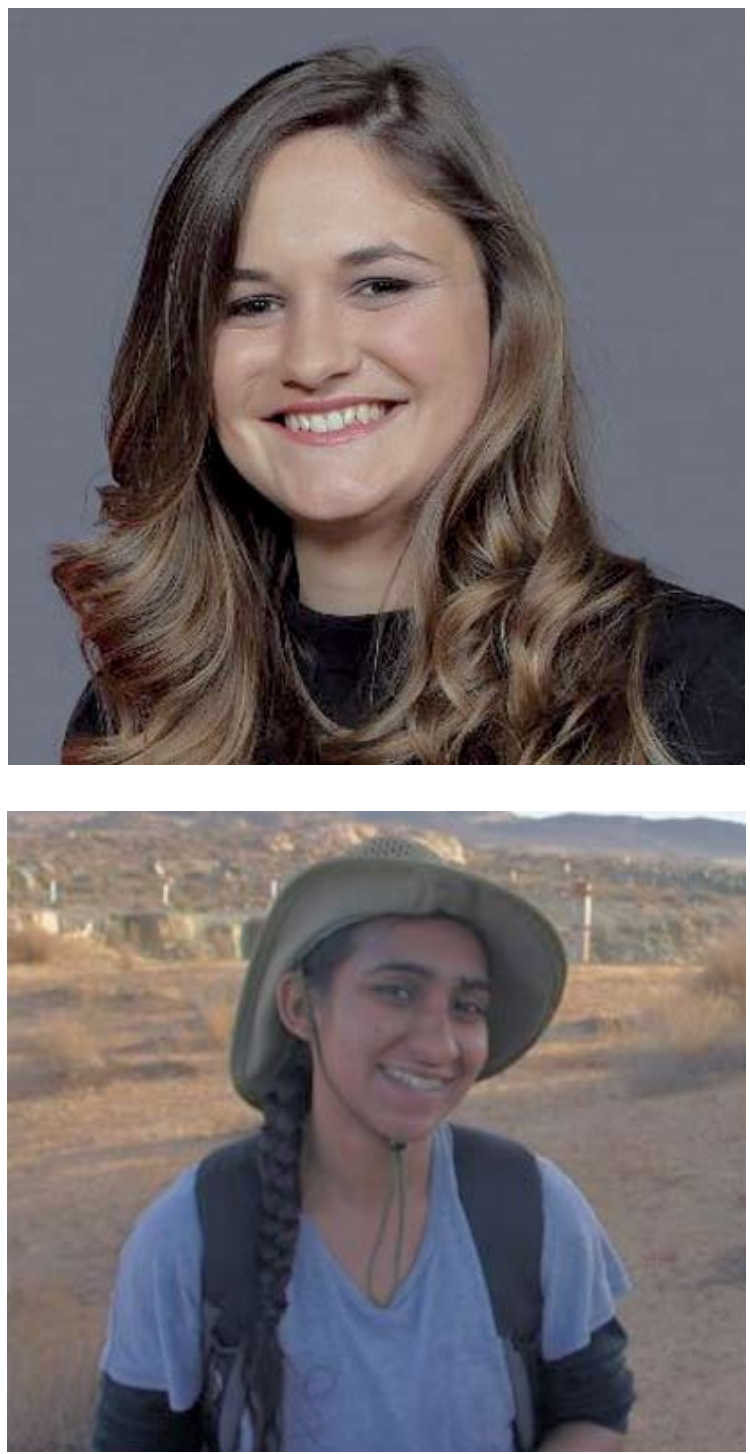

Ending the year on a high note are Lechelle Goslin (pictured above) and Bibi Ayesha Jogee (below). Lechelle and Ayesha were both supervised by Prof. Paul Nex as well as Dr Robert Bolhar and Dr Grant Bybee, respectively. 
government to address matters of urgent socio-economic importance, which in this instance is the standard of teaching and research in the fields of petroleum geoscience and petroleum/reservoir engineering, so that South Africa draws maximum benefit from our local oil and gas industry. Participating staff members from the core academic representatives (Cape Peninsula University of Technology, University of Fort Hare, Nelson Mandela University, University of the Western Cape, University of Johannesburg and Wits), were due to take up short-term placements in petroleum companies and leading research institutes as of March 2020, but the work plan was severely disrupted by the Covid-19 lockdown. Nevertheless, activities relevant to the Community of Practice continued, with Prof. Durrheim reporting that the Wits Schools of Geoscience and Chemical and Metallurgical Engineering (which hosts the MSc in Petroleum Engineering) currently have $17 \mathrm{MSc}$ and $5 \mathrm{PhD}$ students working on research topics relevant to Oil and Gas (this includes topics in rock physics and reflection seismology that are focused on mineral exploration and mining, but can also be applied to oil and gas), with several more scheduled to start in 2021. Researchers from the various universities have also published over 17 papers in the last two years, and four Wits staff members completed a 5-week International Human Resources Development Corporation (IHRDC) Virtual Mentored Learning course in Upstream Oil and Gas.
The move to Lockdown Level 1 and Total's announcement in October of extremely promising results from the well drilled on the Luiperd prospect, about $175 \mathrm{~km}$ off the southern coast, has given new impetus to the Community of Practice, which will hold its inaugural Steering Committee meeting on 27 November 2020.

Dr Sharad Master, as of September 2020, took up his position as 'Vice-President Africa' for the International Commission on the History of Geological Sciences (INHIGEO) for the next four years and was also appointed as the acting Chair of the South African National Committee for the International Union of Geological Sciences/International Geoscience Program (SANC-IUGS/ IGCP).

Last but not least, the School welcomes Mr. Louis Mudalahothe and Dr. Loic LeBras to the team. Louis joins us from Mintek and will oversee aspects of the mineral separation and sample preparation facilities; while Loic returns to Wits to do his postdoc looking at PGEs, Re-Os and sulphides using LA-ICPMS.

Compiled by Sarah Glynn from various departmental contributors.

\section{geological travels}

Geological travels and adventures in the Indian Subcontinent, during the ill-fated $36^{\text {th }}$ IGC, early 2020, at the start of the COVID-19 pandemic.

\section{Part 2: Nepal}

[In Part 1 of this 2-part article, I explained that I travelled to the Indian Subcontinent to participate in the $36^{\text {th }}$ International Geological Congress (IGC) and its excursions, scheduled to take place in February and March 2020. I recounted my experiences in India, including participation in a pre-Congress field trip to the Satpura Gondwana Basin. The IGC, together with its post-Congress excursions, was postponed due to the developing COVID-19 pandemic.]

The high point (both literally and figuratively) of my trip to the Indian Subcontinent was undoubtedly the postIGC excursion to the Himalaya of Nepal. Although the official IGC trip was cancelled, almost all the participants had already booked their tickets to Nepal, and we persuaded the leaders to go ahead with this trip as a private expedition. 


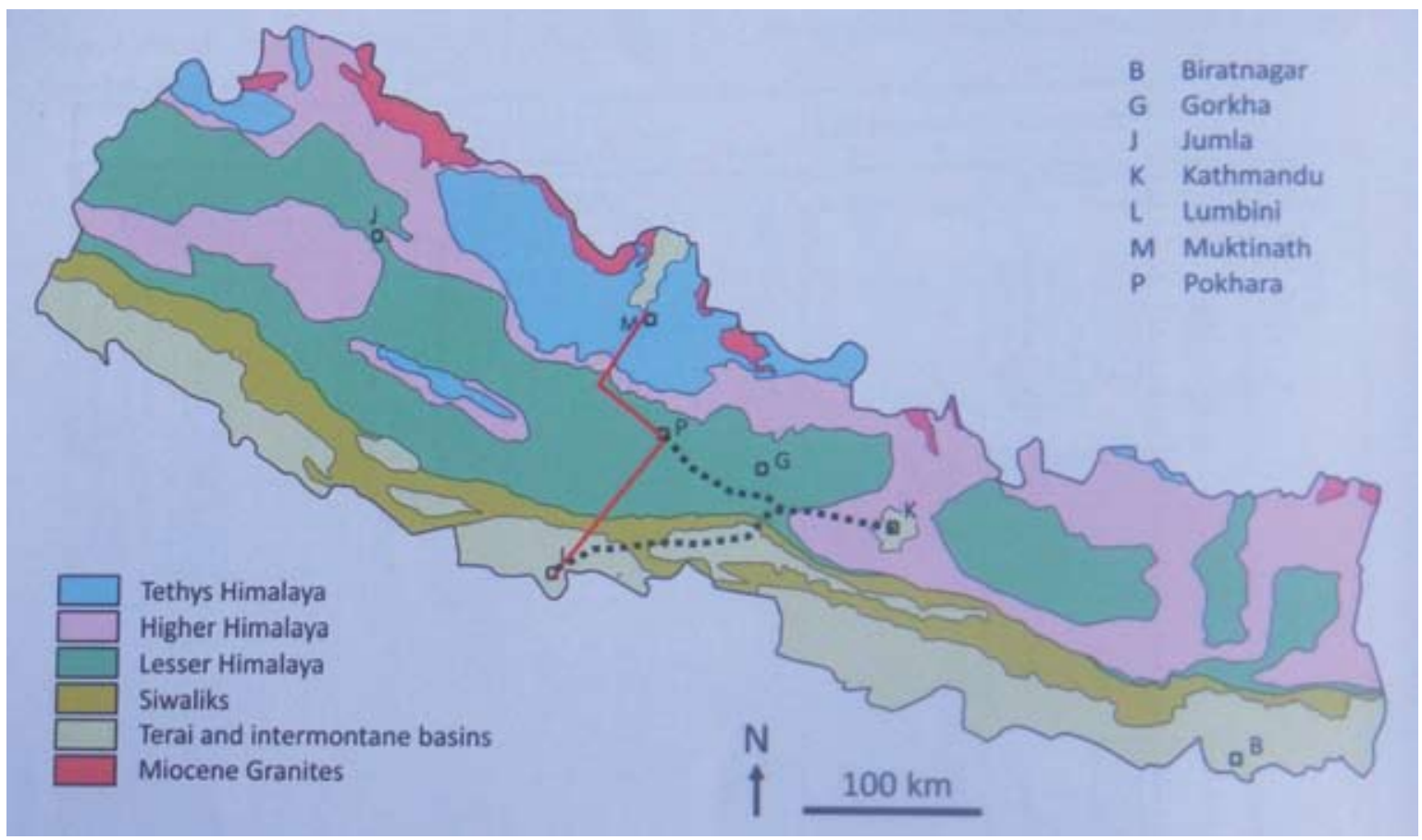

Simplified geological map of Nepal (after Dhital '). The approximate route of my excursion is marked in red, starting at Lumbini in the south of Nepal.

On 8 March 2020, I flew from New Delhi to Kathmandu, and then travelled with a small Yeti Air plane to the tiny airport at Bhairahawa, in southern Nepal, close to the Indian border. On this short flight I caught glimpses of some of the peaks of the High Himalaya gleaming brightly in the late afternoon sun, including Manaslu, made of leucogranite (which had been studied particularly by Patrick Lefort, former French Consul in Johannesburg). For most of the journey, since I sat on the left side of the plane, I was able to view the tangled networks of braided rivers flowing south to the Terai (the lowlands of south Nepal) and the Indo-Gangetic Plains, with their watercourses brightly lit up momentarily by reflections from the setting sun. After landing, I took a taxi in the dark on a poor road to the little town of Lumbini, the birthplace of the Buddha, which is now a flourishing centre of Buddhist pilgrimage, and headed for the Little Buddha Hotel, which was the starting place for our excursion. That night I received news from my travel agent in Johannesburg that India was closing its borders, and I would not be allowed back in for my return flight home-I would have to find another way back, and purchase a new return ticket!

The next day, which was my birthday, I found that the Little Buddha Hotel was conveniently located right opposite the entrance to the Maya Devi or Buddha Birthplace Sanctuary. I took a bicycle riksha to the interior sanctuary, and spent the afternoon visiting the holy of holies, the supposed site of the Buddha's birth in 563 BCE (where there is a square temple built around the spot). It is adjacent to a sacred pool where the Buddha's mother Queen Mahamayadevi had supposedly bathed, next to an imposingly large sacred pipal fig tree (Ficus religiosa), which provided shelter for a sizeable gathering of Buddhist monks and acolytes, dressed in orange robes, engaged in silent prayer and meditation. This sanctuary had been lost for millennia, until in the late $19^{\text {th }}$ Century,

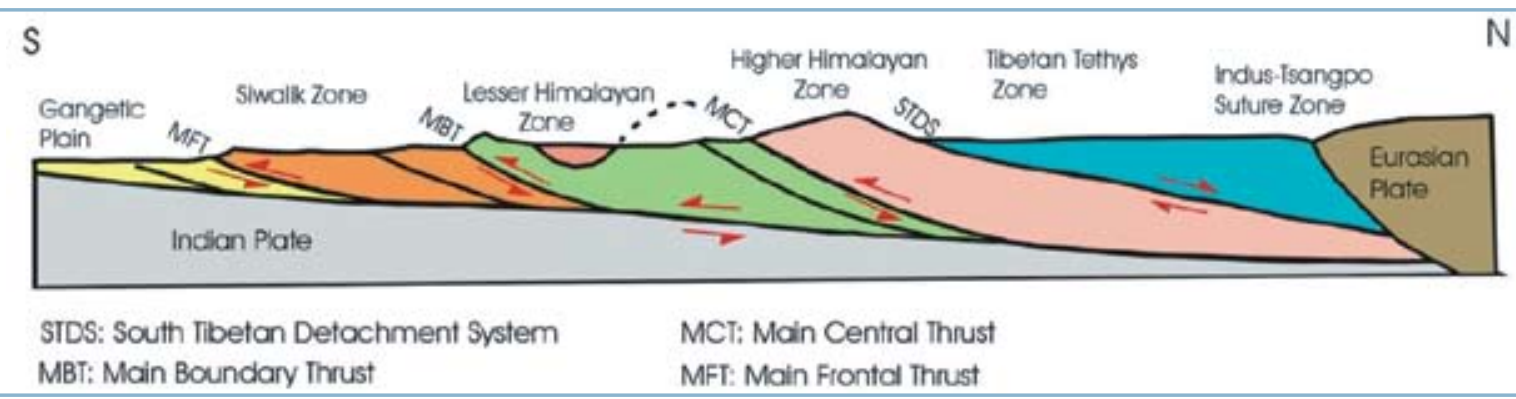

Generalised cross section across the Himalaya (after Harris et al. ${ }^{2}$ ). 
Birthplace of the Buddha (born $6^{\text {th }}$ Century BCE) at Lumbini, South Nepal, with the sacred pool of Queen Mahamayadevi. The Ashoka Pillar, with inscriptions dating from the $3^{\text {rd }}$ Century BCE is on the left.

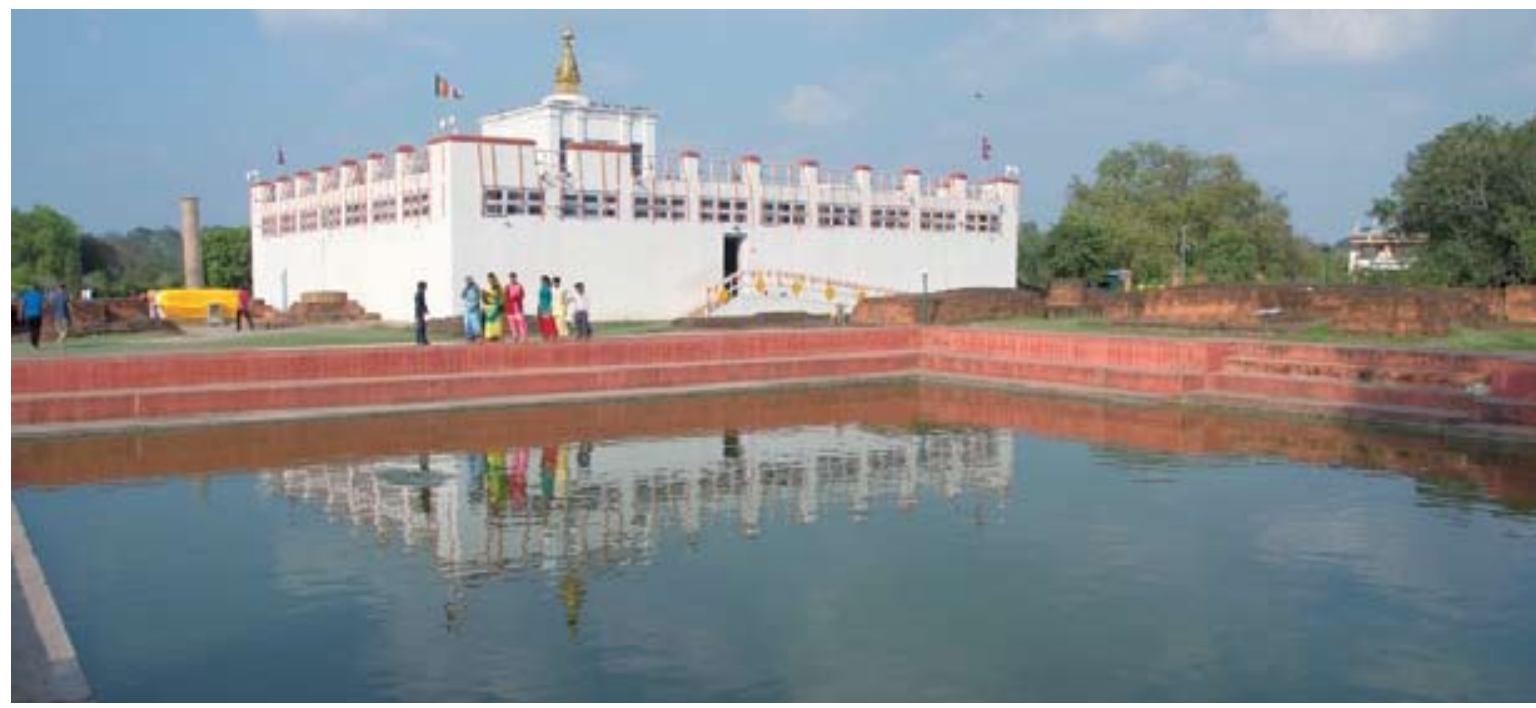

when a stone pillar with inscriptions that had been erected by the great Emperor Ashoka in the Third Century $B C E$ was discovered next to the ruins, announcing this site as the birthplace of Gautama Buddha. The small pebbles in the stream that ran through the Sanctuary were made up of a mixture of many different rock types - these were derived from the Himalaya to the north, Lumbini being

North-dipping fossiliferous Miocene Siwalik sandstones (c.11 Ma), in the Tinau River at Butwal.

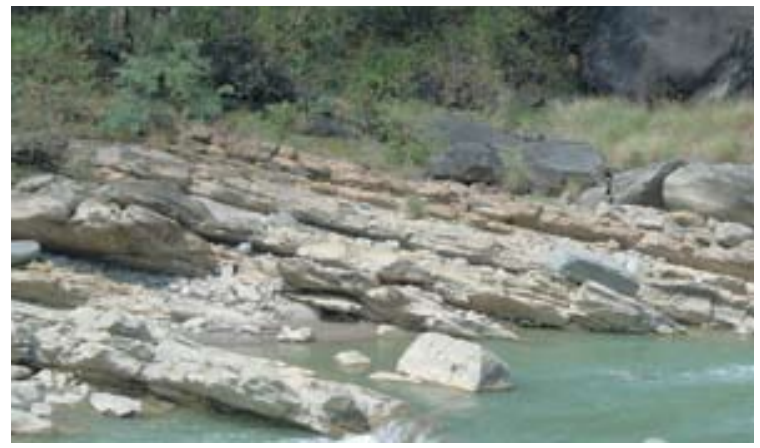

Fossil burrow (left) and palm stem (right) in Miocene Siwalik sandstones, Tinau River, Butwal.

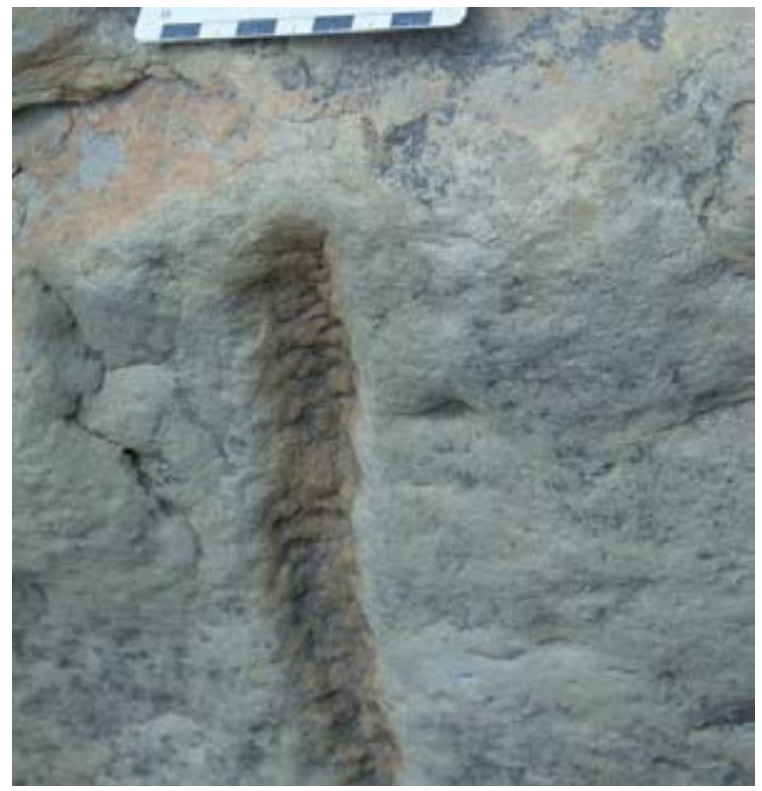

situated in the Indo-Gangetic foreland basin resulting from the erosion of the mountains.

After my return from the Maya Devi Sanctuary, I found the rest of the excursion members, who had arrived overland from Kathmandu. The Himalaya excursion was expertly led by professors Lalu Paudel and Khum Paudayal from Tribhuvan University in Kathmandu, assisted by Prof. Joern Krühl from TU Berlin, and Ram Rijal of Himalaya Research Expedition (in charge of logistics). In addition to the leaders, our group consisted of three academics from Mexico, three members of the Czech Geological Survey,

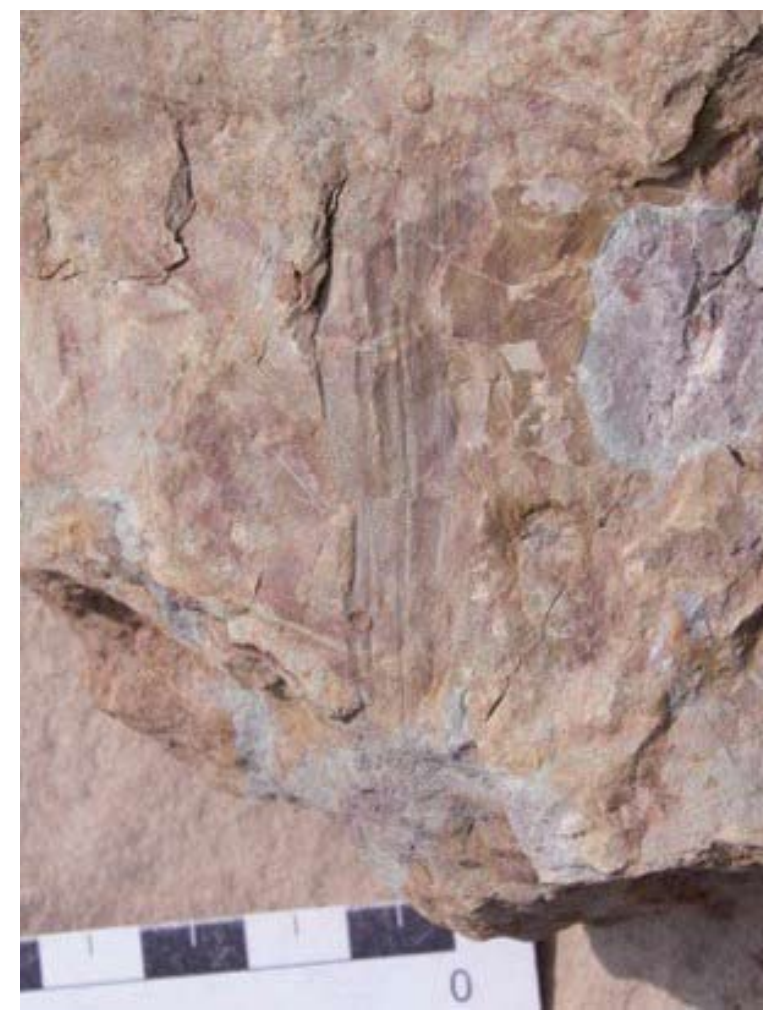


a German professor, and myself. Because the official IGC excursion had been cancelled, the printed guidebooks had not been forwarded to Nepal by the IGC Secretariat. So our leaders had to print out a new set of guidebooks, maps, papers, and itineraries, and they were busy sorting them out in time for the start of the excursion the next morning. That night we gathered for dinner at a Chinese Restaurant, where I got introduced to Nepalese Beer, of which there are several varieties, all excellent, with names like Sherpa, Everest, Himalayan Dragon, etc., and all very expensive, at about $\$$ US4.50 per $750 \mathrm{ml}$ bottle.

The Nepal Himalaya excursion was a transect across the Central Himalaya, starting in the Terai (in the IndoGangetic Plain) at Lumbini (elevation $100 \mathrm{~m} \mathrm{ASL),} \mathrm{and}$ moving northwards into progressively higher and more metamorphosed structural domains, at increasing altitudes, along the Kali Gandaki gorge, until the end point that was at the great Buddhist and Hindu pilgrimage site of Muktinath, at an elevation of $3800 \mathrm{~m}$ ASL.

After leaving Lumbini, and crossing the Himalayan Front (marked by the Main Frontal Thrust, not seen on this section, which separates the unconsolidated foreland

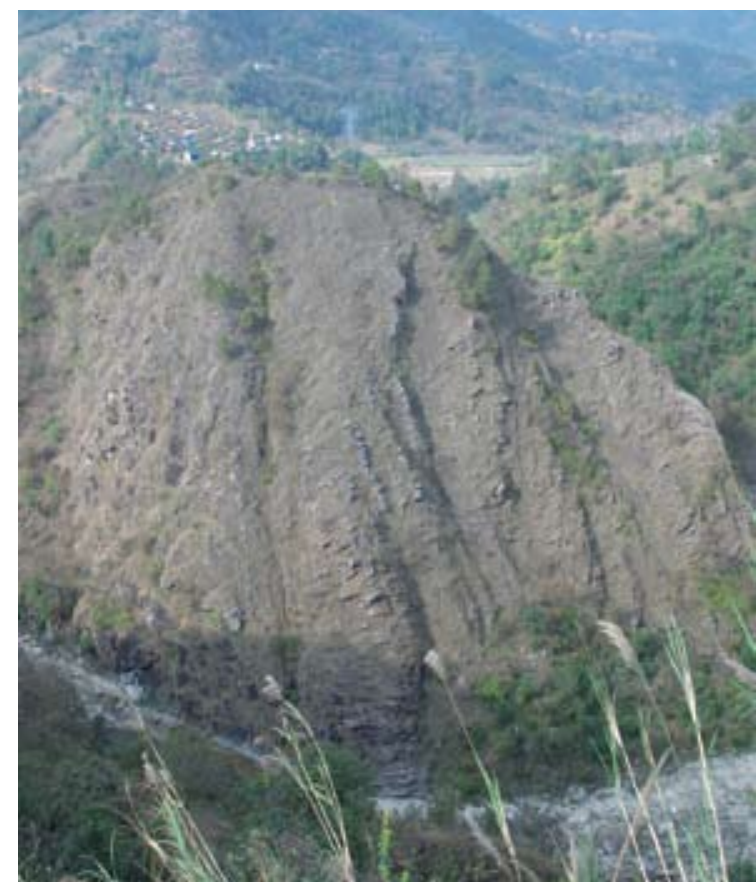

Outcrops of low-grade metamorphosed Palaeoproterozoic rippled sandstones (Naudanda Formation) in the Lesser Himalaya south of Tansen.

basin sediments from deformed sediments), the first excursion stop was at Butwal along the Tinau River, to see north-dipping Miocene fossiliferous sedimentary rocks of the Siwaliks, where an 11 Ma tooth of the hominid Ramapithecus (or Sivapithecus) had been found in 1980. In these Siwalik sandstones and siltstones, cylindrical vertical burrows, and fossil plants, including palm stems, were seen. We then entered the Lesser Himalayas by traversing through the Main Boundary Thrust, which

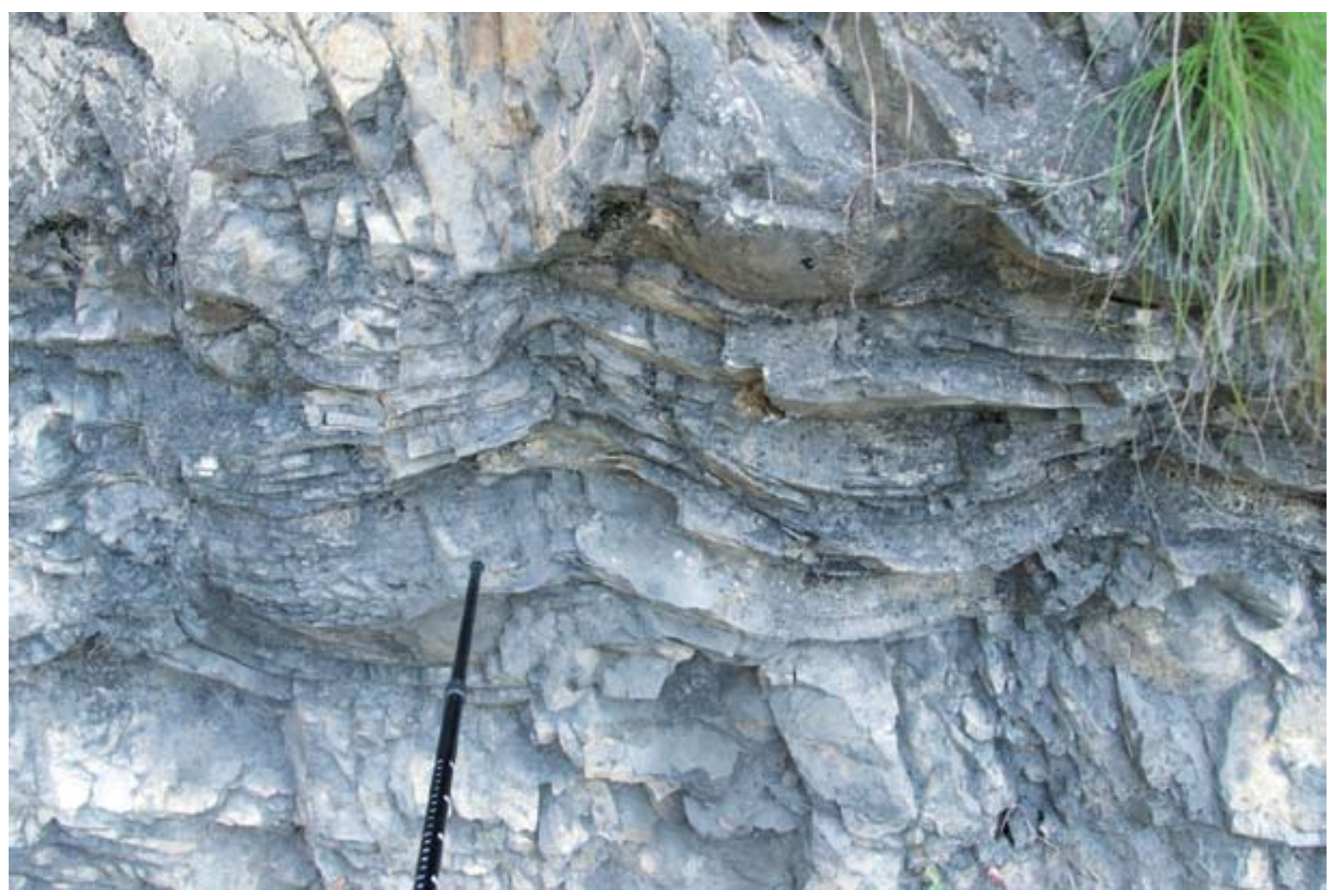

Inverted carbonate stromatolites of the Neoproterozoic Khoraidi Formation, on the downward-facing limb of a recumbent nappe structure, in the Lesser Himalaya. 
Panorama from the World Peace Pagoda, overlooking Phewa Lake, the hills behind Pokhara, and the Himalaya. Dhaulagiri is the peak on the far left, the other peaks belong to the Annapurna range, together with the triangular peak of Machhapuchhare. At the summit of the dark ridge on the right is Sarangkot.

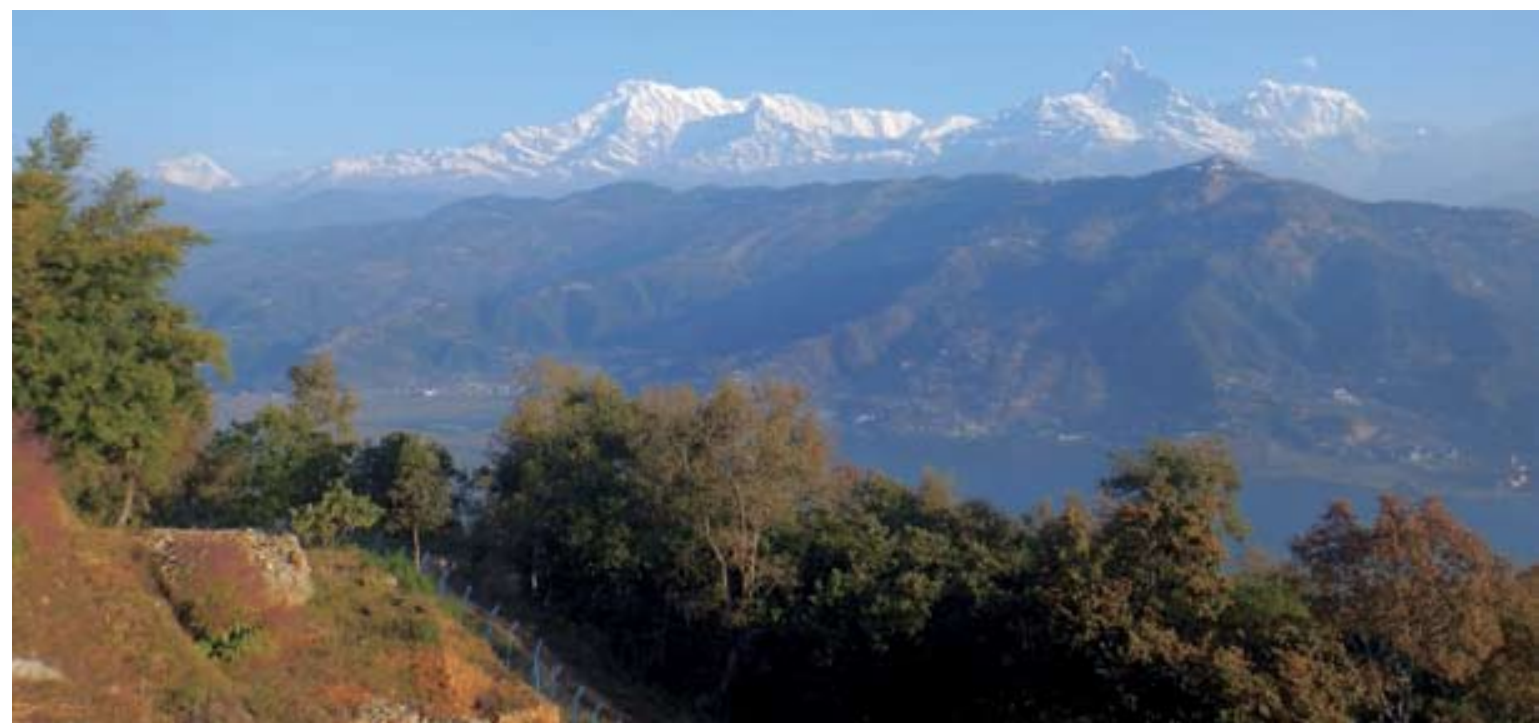

is overlain by a folded sequence of Neoproterozoic stromatolitic carbonate rocks (a deformed carbonate platform that extends for $600 \mathrm{~km}$ WNW all the way to the Kumaon Himalaya of Northern India). Infolded along with these are Mesozoic Gondwana and Oligocene to Miocene post-Gondwana fossiliferous sediments of the Tansen Group. In the early to middle Miocene Dumri Group (15-10 Ma, similar in age to the oldest Siwalik rocks), we saw a $3 \mathrm{~m}$-long intact tree trunk encased in situ in sandstones. We did a road traverse of superbly exposed Neoproterozoic stromatolitic carbonates of the Khoraidi Formation, completely overturned, in the downwardfacing limb of a recumbently folded nappe structure. Structurally overlying these rocks is a thick sequence of ripple-marked quartzites (Naudanda Formation) of Palaeoproterozoic age.

After an overnight stay at the hill town of Tansen Palpa, situated on a prominent ridge at $1350 \mathrm{~m} \mathrm{ASL}$, from where there are spectacular views of the Dhaulagiri and Annapurna Himalaya, we continued northwards, descending to $820 \mathrm{~m}$ to Pokhara (the second-largest city of Nepal). Pokhara is situated on the shores of Phewa Lake, which was formed when a river was dammed by a major landslide at around 1170 CE. From the World Peace Stupa on a hill overlooking the Phewa Lake and Pokhara, we had a great panoramic view of the Annapurna Range, including the peaks of Annapurna I, II, III and IV, and the triangular peak of Macchapuchhare or Fishtail, which, being closer, appeared taller than the rest. In Pokhara we visited by boat an island on Lake Phewa, thronging with devout visitors to a Shiva temple, from where one could get splendid views across the placid lake to the snow-covered high mountain peaks. The landslide that produced the Phewa lake is made up of huge blocks of Tethyan carbonate rocks, which have undergone karstification and cave formation. We visited the Davis Falls, which are situated in this rare type of karst terrain, where the Pardi Khola stream disappears in a subterranean cave system within the megablocks. The

Phewa Lake at Pokhara, with Machhapuchhare and the Annapurna Range in the background. The lake resulted from the damming of a river by $a$ huge landslide around 1170 CE.

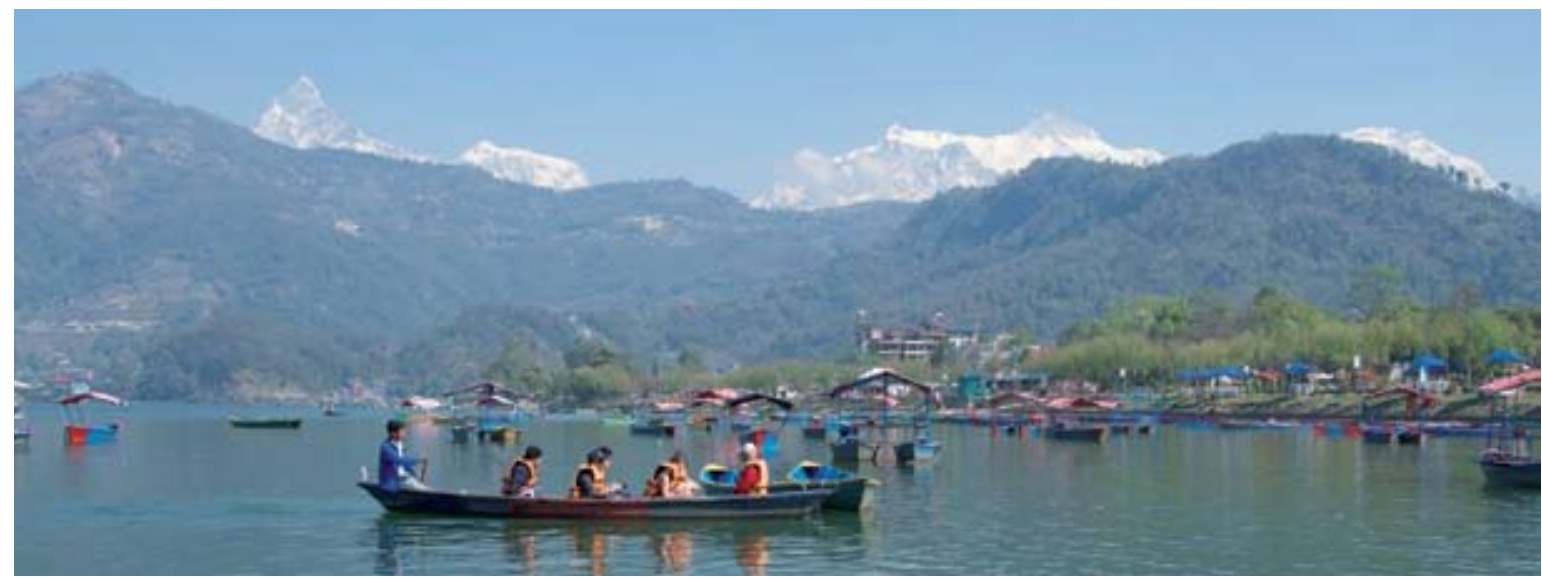


falls (originally called Patale Chhango) were renamed after an unfortunate Swiss tourist, a Mrs Davis, who was drowned here in 1961 while swimming - but its name is referred to in the Nepali vernacular as "Devi's Falls", or the Falls of the Goddess. Another karst feature, the Mahendra Cave, was formed in laminated lacustrine clastic carbonate sediments that had been deposited in the dammed-up Phewa palaeolake that formed after the landslide. In an interior panel in this cave, a shrine had been erected to the Hindu god Ganesh, and little towers of balanced rocks had been placed on a ledge above it.

One of the most interesting places in Pokhara is the International Mountain Museum, which has displays on the different Nepali tribes that inhabit the Mountainous region (including the Sherpas and Gurkhas), and on the major mountaineering expeditions that have conquered the high mountains of the Nepalese Himalaya. There is also a display highlighting the pioneering geological mapping efforts of the Swiss geologist Toni Hagen, and a collection of rocks from the Himalaya (put together by Prof. Paudel). It was a pleasant surprise to see displayed there the new geological map of the Mount Everest Region compiled by Prof. Mike Searle of Oxford University, published with partial sponsorship from South African geologist and commodities analyst Rene Hochreiter (a former undergraduate classmate of mine from the late 1970s, who had more recently done MSc research at Wits on the Geology of Everest Base Camp).

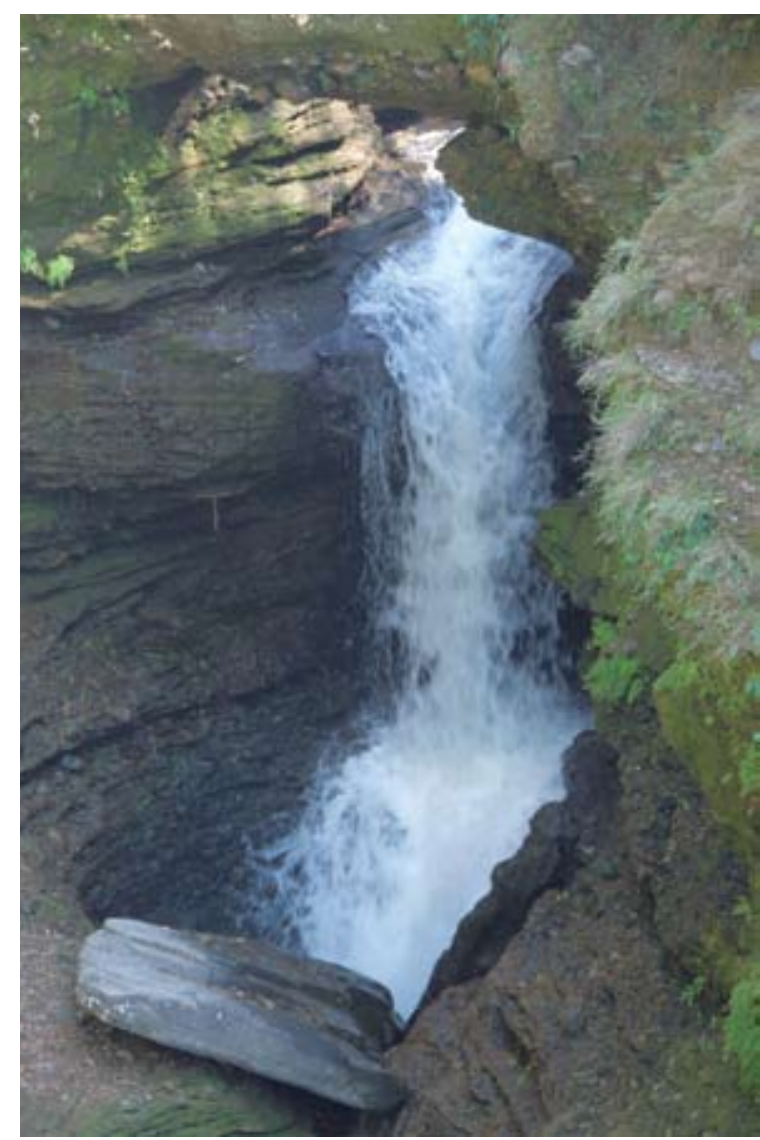

The Davis Falls (Patale Chhango) in Pokhara formed where the Pardi Khola stream disappears into a karst structure in limestone megablocks of the huge landslide that occurred in c. 1170 CE.

After leaving Pokhara, our first stop was at Sarangkot, where we had scenic views from our hotel over Pokhara and Phewa Lake to the south. A steep climb took us to the summit of the hill behind our hotel, where we were rewarded with a magnificent spectacle of the Annapurna Range to the north. Far below us was the Seti Nadi (i.e., Seti River) with several uplifted terraces, on the highest of which were crowded together the buildings of an

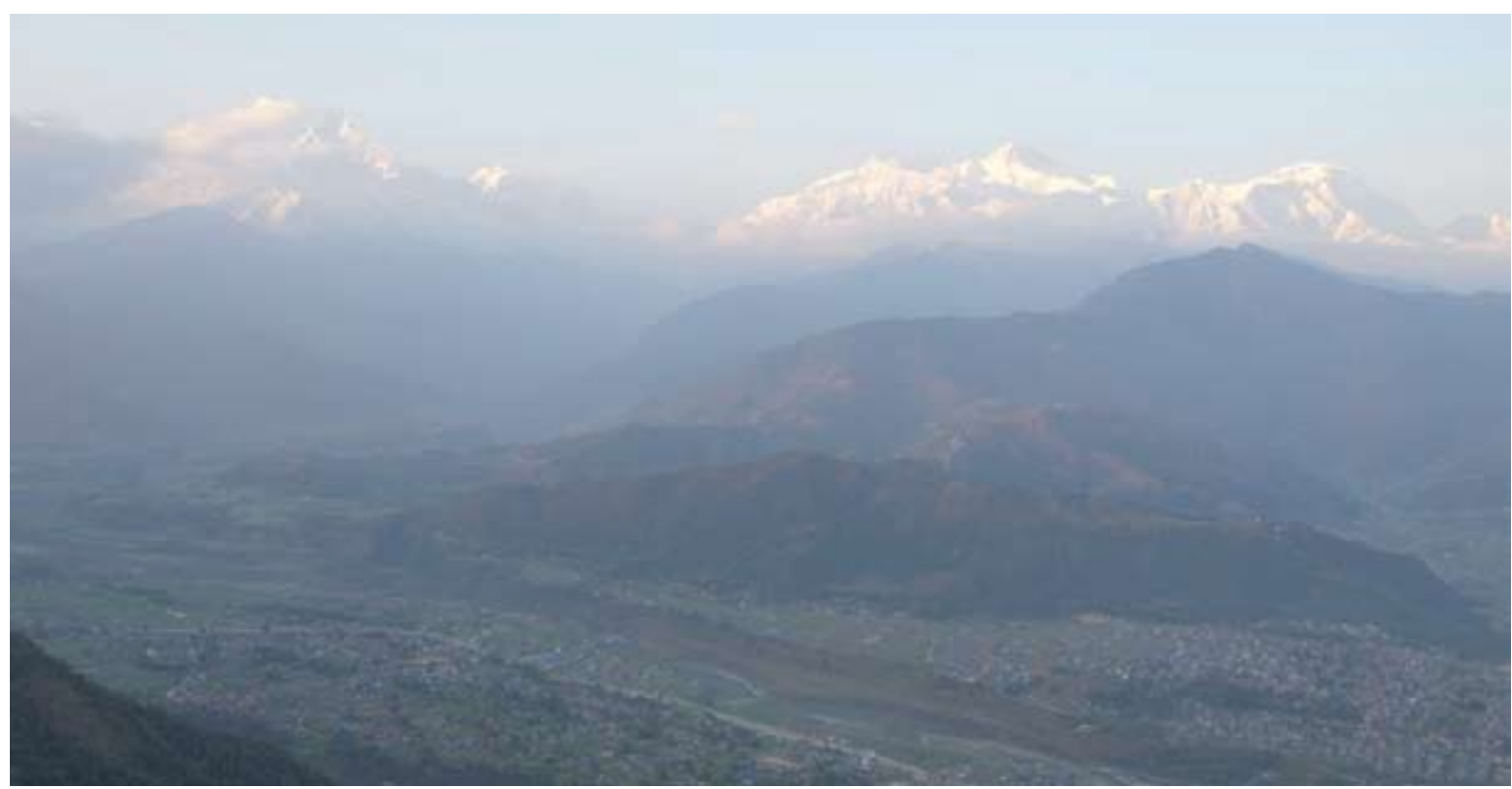

View of the Seti Nadi and its terraces, north of Pokhara, with Machhapuchhare and the Annapurna Range in the background, still lit up by the setting sun. 
encroaching settlement in the northernmost suburbs of Pokhara. Here we lingered, expectantly savouring the last golden rays of the setting sun lighting up the highest peaks, long after the rest of the district had been enveloped by the darkening shadows.

Having switched at Sarangkot into four-wheel drive vehicles, we continued along a winding circuitous road until we encountered the Kali Gandaki River, and followed it north towards its source in the Tibetan Plateau. The Kali Gandaki is one of the most remarkable rivers in the world-it is an antecedent river, which was already flowing south from Tibet prior to the slow tectonic rise of the Himalaya mountain range during the collision of India and the Lhasa Block, which started about 55 Ma. As the mountains rose (and are still rising) at a rate of a few $\mathrm{cm}$ per year, the powerful braided river, through its erosive agency, kept cutting down at the same rate. The result is the greatest gorge on planet Earth. Two of the world's highest mountains, Dhaulagiri (8172 m ASL) and Annapurna I (8091 m ASL), whose summits are only 36 km apart, are separated by the gorge of the Kali Gandaki, at an elevation of $1200 \mathrm{~m}$, so that there is a vertical topographic relief of almost $7 \mathrm{~km}$ ! In some places the Kali Gandaki valley is a floodplain several $\mathrm{km}$ wide, while in its narrowest portion it is in the form of a steep-sided gorge only about $7 \mathrm{~m}$ wide.

Our lunch stop at Galeshwar overlooking the river was in a restaurant built precariously on top of very large boulders that had come down a steep mountain slope in a debris avalanche. Signs of mass wasting are ubiquitous in Nepal-landslides, debris slides, debris flows, rock falls, and very commonly, colluvial cones. We overnighted in the town of Tatopani, from where we enjoyed a clear view northwards of the glaciated triangular peak of Nilgiri South (6839 m), part of the Annapurna Range. As soon as we unpacked, we headed down to the famous thermal springs on the banks of the Kali Gandaki River, where we had a refreshing and relaxing evening dip in the steaming waters, sipping cold beers, while enjoying good conversations, swopping anecdotes, and planning future collaborations, while surrounded by high mountain peaks. This experience, viewed in the hindsight of the last few apocalyptic months, cooped up in claustrophobic, anxiety-ridden isolation, seems otherworldly now!

The next day we started heading towards the High Himalaya. Ice-covered mountain peaks of the Annapurna range were now on our right, while the peaks of the

The Riverside Hotel at Galeshwar, on the banks of the Kali Gandaki, built on top of huge boulders that had rolled down from a high mountainside.

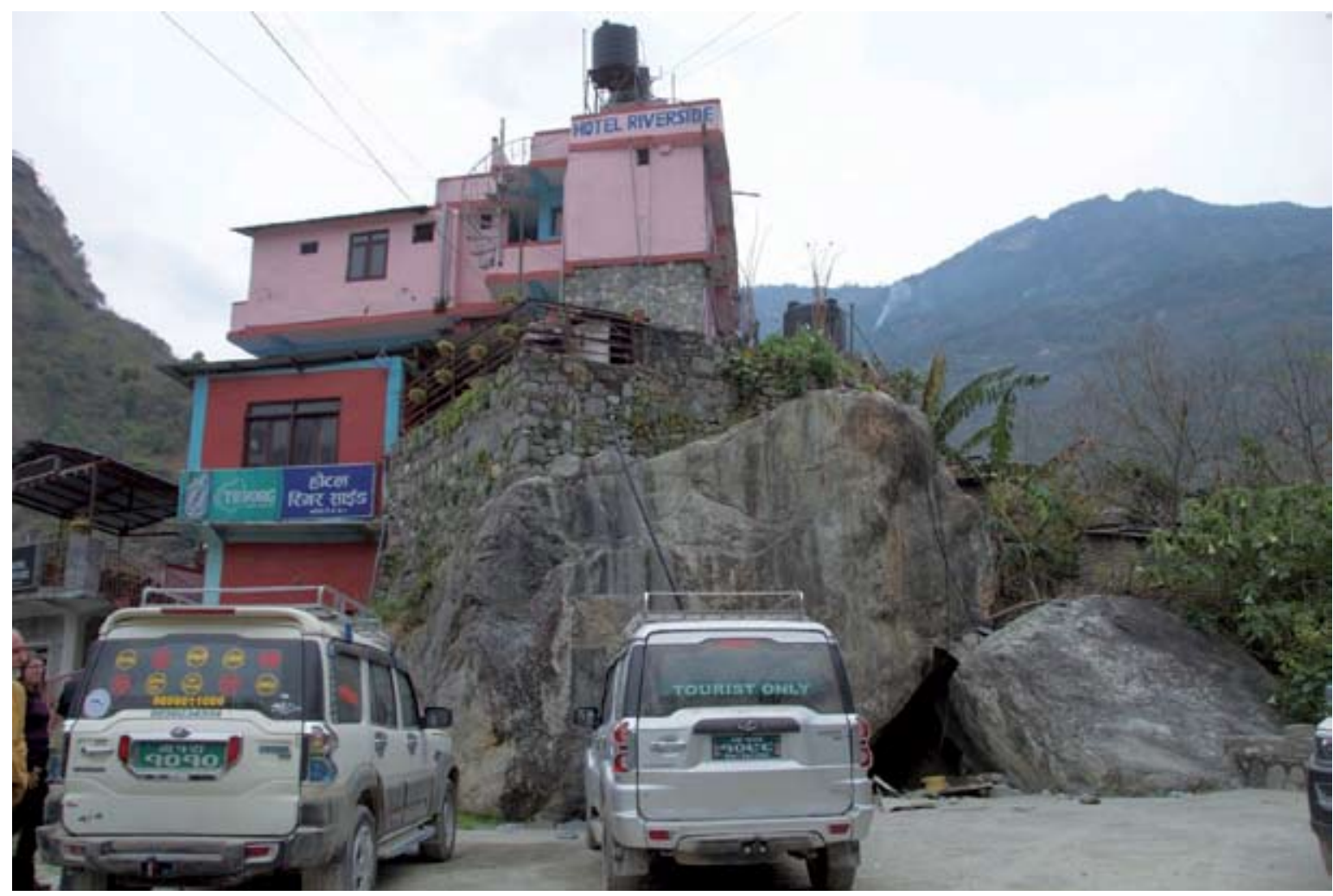




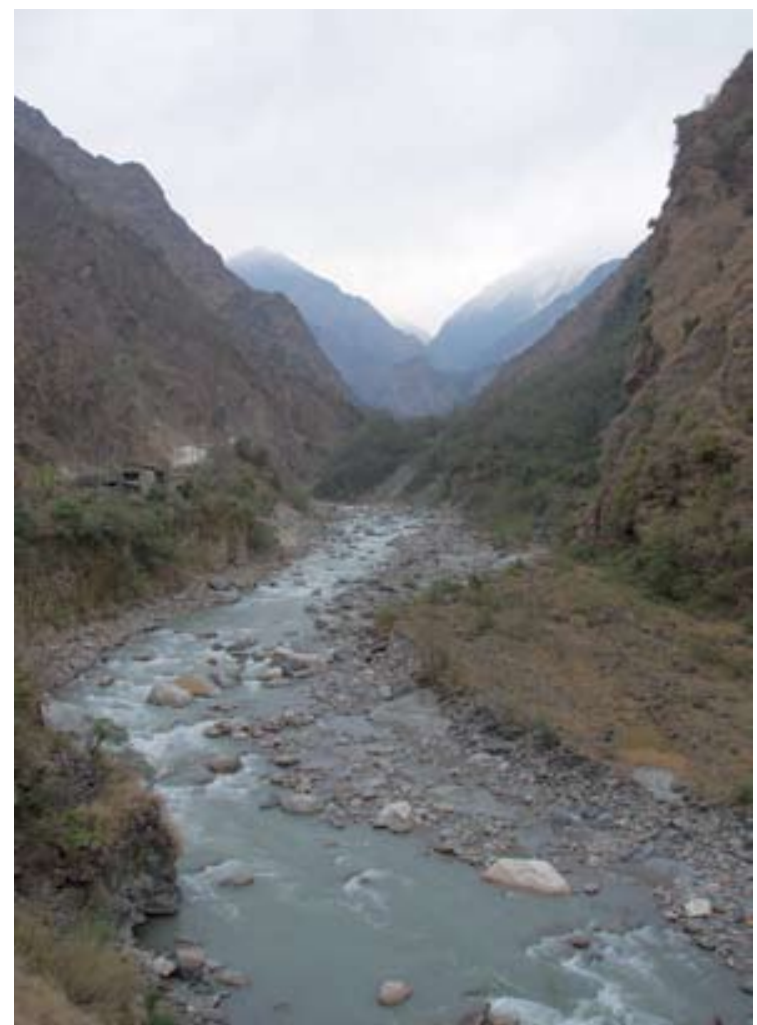

Looking upstream along the gorge of the Kali Gandaki river, which descends from the High Himalaya in the background. The road following the river can be seen snaking alongside it on the left.

Dhaulagiri group were on our left. We coursed along the Kali Gandaki floodplain, sometimes on the right bank, and sometimes on the left bank, after crossing over the braided river on narrow bridges, or driving through shallow water and exposed conglomeratic bars. We encountered the Main Central Thrust (MCT) of the Himalaya Orogen in spectacular, fresh outcrops. Here there are north-dipping highly sheared mica schists and phyllonites, showing a top-to-south thrust sense of shear, with down-dip striations and mineral stretching lineations. Upon crossing the MCT, there is a change in lithology and metamorphic grade, from the lowgrade Proterozoic metasedimentary rocks of the Lesser Himalaya, to the amphibolite facies almandine-kyanite schists, gneisses and marbles of the Higher Himalaya, which were thrust southwards over the Lesser Himalaya, as shown by kinematic indicators. The high-grade metamorphic rocks of the Crystalline High Himalaya are believed to be metamorphosed equivalents of the rocks of the Lesser Himalayas. They are intruded by large bodies of syn-collisional Miocene granites (such as at Manaslu), but these are not exposed on the Kali Gandaki traverse.

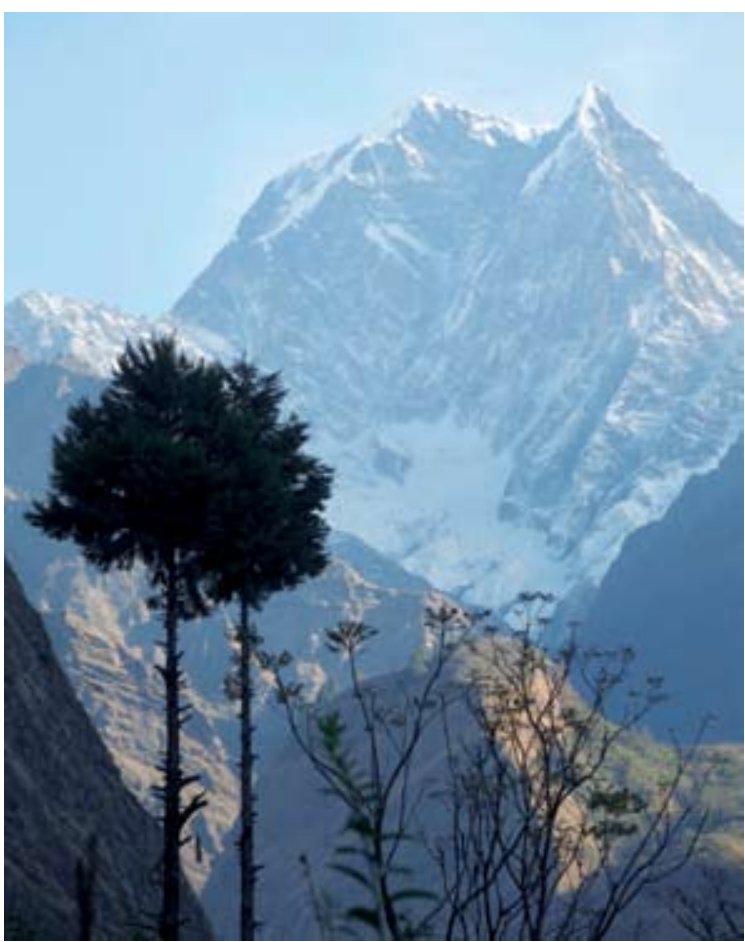

Nilgiri South $(6839 \mathrm{~m}$ ASL), in the Annapurna Range, viewed from Tatopani.
Just as in The Amazing Race, our expedition then hit a major roadblock — but this one was for real: it was caused by a landslide. Since we were on a narrow roadway cut into the high banks overlooking the Kali Gandaki, there was no way around the obstacle. A small front-end loader was busy trying to clear the obstruction, and while our vehicles waited, we hiked ahead for a few km, enjoying the high mountain scenery, while griffon vultures with their huge splayed wing feathers circled in the sky. At length we were rejoined and picked up by our convoy of three vehicles, but we had lost an hour and a half by then. In the area near Larjung, we came close to the Dhaulagiri Massif, which was mainly shrouded in clouds. We caught glimpses of the Dhaulagiri Glacier, and then shortly after we found ourselves driving through the terminal moraine of this great Himalayan glacier, which had receded substantially. The moraine consisted of an unsorted pile of debris, forming irregular mounds some 40 or $50 \mathrm{~m}$ high, containing angular blocks of all sizes, even as large as a house, sitting in a finer-grained clayey matrix. One of our vehicles had some trouble in the chassis, and while our very capable drivers fixed the problem, we examined the moraine.

Because of lost time, we missed seeing the exposures just south of Larjung of the South Tibetan Detachment, 
a north-dipping normal fault system, in the hangingwall of which is exposed a vast expanse of low-grade (but spectacularly folded) marine sedimentary rocks of mainly Mesozoic age. These rocks were deposited on the margins of the Neotethys Ocean, which closed as the Indian continental plate moved closer to the Lhasa block prior to the collision that gave rise to the Himalaya Range. It was late afternoon when we got to our next overnight stop, at the town of Marpha, renowned for its apple orchards, nestled at the foot of a huge cliff, which provides shelter from the cold Himalayan winds. It has an imposing

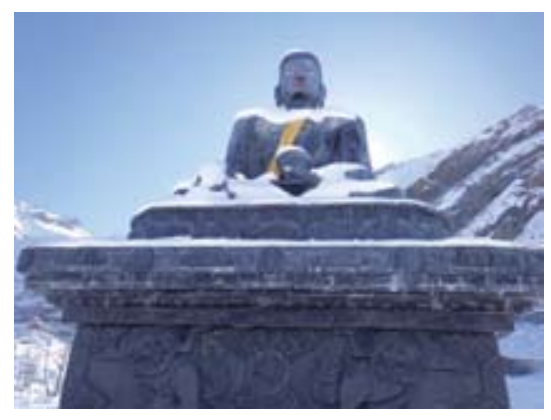
Tibetan Buddhist monastery, on the side of the cliffs, with a magnificent view over the town below, where the flat rooftop of every house bristled with its winter supply of neatly stacked firewood. Accompanied by a couple of my colleagues, I ascended the steep stairs to the monastery,

Statue of the Buddha turning the myriads of prayer wheels laid out in serried at Muktinath, at an elevation of $3800 \mathrm{~m}$ ASL.

ranks next to the stairs, cyclically repeating the words of the popular Sanskrit mantra: "Om mani padme hum" (Hail to the Jewel in the Lotus). We then strolled through the narrow winding streets of old Marpha, paved with cobblestones and sandstone slabs, until we found a teahouse, where we were refreshed with hot lemon ginger tea. After supper where we sampled the excellent local cider, we retired early to our cold, unheated rooms. Being tired, I slept deeply, blissfully unaware of what was happening outside.

I was greeted with an astonishing sight the next morning, as I looked out of the window-everything was covered in brilliant white snow, gleaming brightly in the morning sun! The apple trees were all snow-covered, and the whole

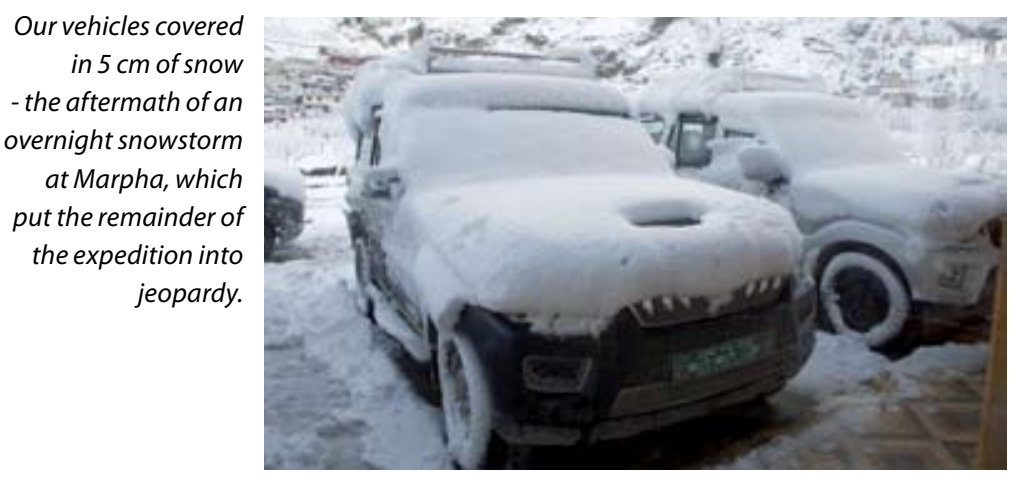

town of Marpha, and the surrounding cliffs, took on the appearance of an alpine ski-resort! I hurried downstairs, to where my colleagues were having breakfast in an atmosphere of mingled exhilaration and impending gloom - would the expedition be able to carry on? Our vehicles, parked outside, were covered in $5 \mathrm{~cm}$ of fresh powdery snow, and the road had disappeared, blending into the whiteness. In places, sheets of ice covered the road. We were at an elevation of close to $2670 \mathrm{~m}$, and these mountain roads are normally closed to traffic in winter because of the snowdrifts. Our leaders were glued to their cellphones, anxiously awaiting news of the condition of the road ahead. There were already reports of blockages near the next town, and our departure was delayed for a couple of hours. In the meantime, some passing buses had carved a visible roadway through the snow, allowing us to follow in the trail they blazed, which soon turned into a muddy rut, greatly impeding our progress. On the road we passed hardy hikers, caught out in the unseasonable snowfall, and unbelievably tough pilgrims, walking through the snow and slush with their bare feet clad only in open-toed sandals! We soon came upon the next roadblock, just outside the town of Jomsom, where there was a line of vehicles held up while a pole carrying live electricity cables, which had collapsed across the main road due to the heavy snowfall, was being cleared. Jomsom has the most northerly airfield along the Kali Gandaki gorge, and is the entry point for visitors to the long-forbidden, and still restricted, region of Mustang, with its fabled closed city of Lomanthang, just south of Tibet, where an authentic form of Tibetan Buddhism is still practiced. Just north of Jomsom, the Kali Gandaki assumes a very different aspect-it becomes a complex system of shallow anastomosing branches separated by gravel and conglomerate-rich sand bars, occupying a wide floodplain. This occupies what was a temporary palaeolake formed by an ancient landslide close to Kalopani, some $20 \mathrm{~km}$ south of Jomsom. It continues northwards (up-river) for about $10 \mathrm{~km}$, to the town of Kagbeni, situated at the foot of a spectacularly dramatic cliff exposure of vertically dipping folded Tethyan sedimentary rocks. This part of the Kali Gandaki valley, called the Thakkola section, has some of the most impressive folded mountain scenery in the world- 


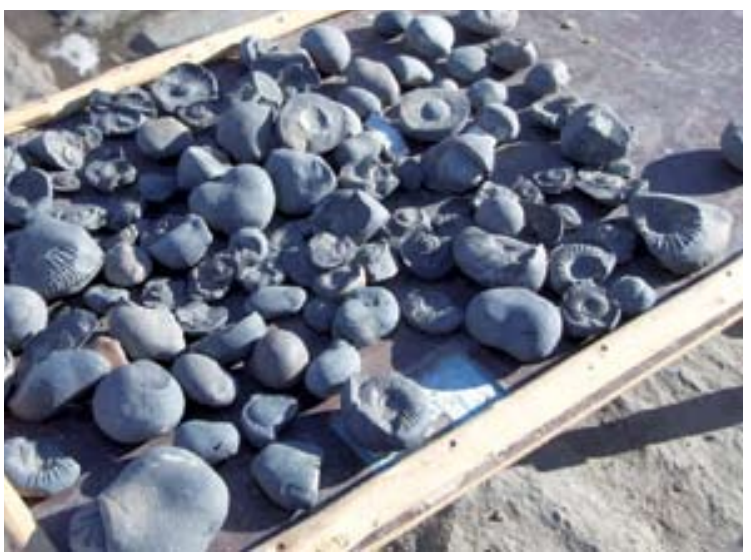

Pebbles with Upper Jurassic ammonite fossils from the Kali Gandaki River section between Jomsom and Kagbeni, seen here for sale in Muktinath.

Nilgiri shows a vertical section through a complete largescale recumbent isoclinal fold, several $\mathrm{km}$ in extent! We stopped to see some Tethyan Jurassic limestones with fossil pelecypods of the Lumachelle Formation near Eklebhatti. In the pebbles of the Kali Gandaki river, there are many large coiled ammonite fossils, weathered out from black Jurassic limestones. They are called "salgrams" and being highly prized sacred stones, which feature in Hindu mythology, they are ubiquitous in curio shops all over Nepal. The word "ammonite" is derived from the name of Ammon (or Amun), a mythical Egyptian god depicted with a ram's head, which has spiral horns similar to the fossil shell. Ammonites, named by the naturalist Pliny the Elder (23/24-79 CE) in his Natural History, were also sacred in ancient Roman culture.

We continued our journey through the Kali Gandaki floodplain, where the snow-covered hillsides were beginning to thaw. Through the influence of winds, pieces of loosely piled snow would detach themselves from the steep slopes and start tumbling down to form "Swiss Rolls" rather than snowballs-a very rare meteorological phenomenon. We came to a viewpoint overlooking the steep cliffs towering over the town of Kagbeni. Close by was a giant $17 \mathrm{~m}$-diameter replica of a salgram, painted black—surely the largest "ammonite" in the world! We continued now in an easterly direction, climbing steadily in altitude, going past small clusters of houses in villages along the pilgrimage route to Muktinath, our destination, which we reached in the late afternoon. There was a problem here-the main street

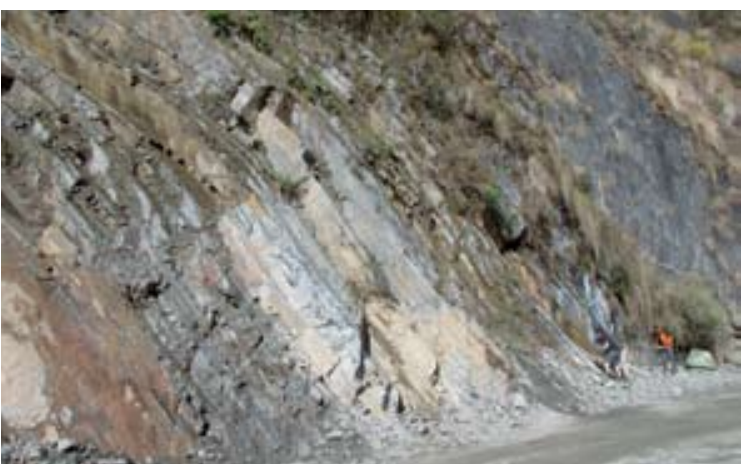

Steeply north-dipping sigmoidal outcrop of the Main Central Thrust.

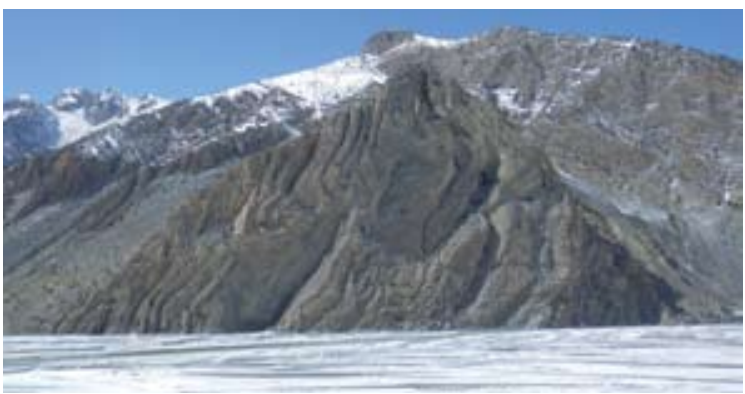

Folded Tethyan sedimentary rocks of the Thakkola section, Kali Gandakigorge.

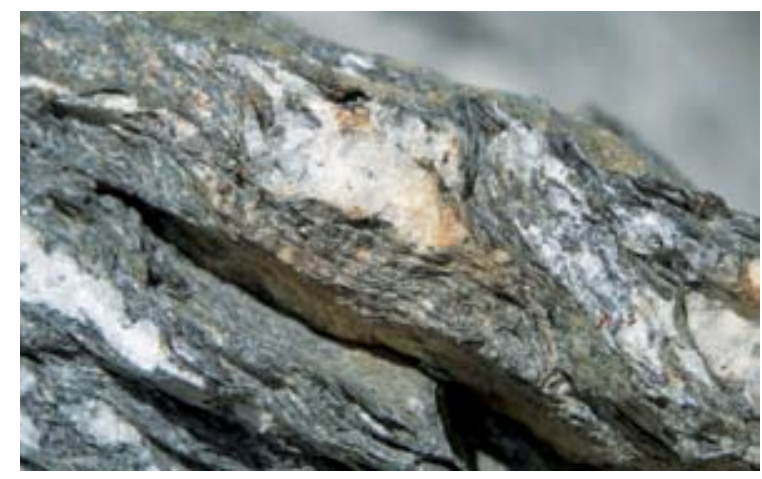

Amphibolite grade Biotitegarnet-kyanite schist with quartz boudins, with sigmoidal kinematic indicators showing top to the left thrust-sense of shear. High Himalaya Zone, above the Main Central Thrust.

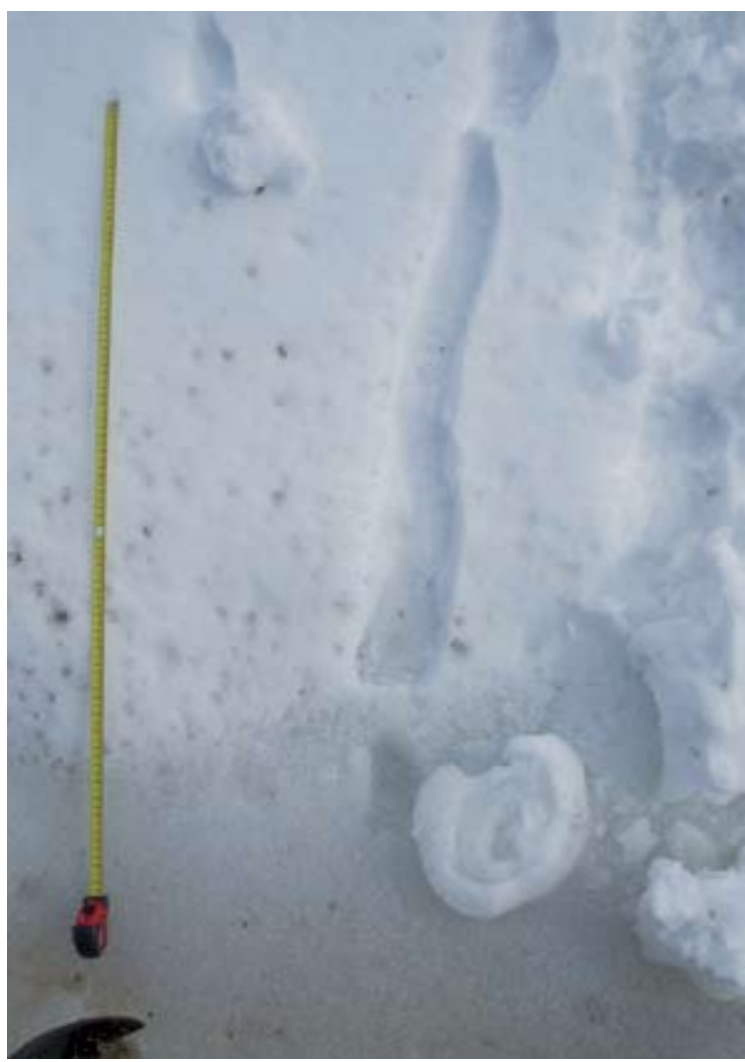

A couple of "Swiss Rolls" made of coiled snow that rolled down steep slopes, a day after a snowstorm dumped $5 \mathrm{~cm}$ of fluffy snow on the area. Tape measure is a metre long. 
into Muktinath was closed to all vehicular traffic until the first of April (it was now the $15^{\text {th }}$ of March). So, leaving our vehicles parked below the town entrance, we had to trudge uphill for a good few hundred metres along the main road, which had by now been converted into a slippery muddy icy sludge. After a long, circuitous slog, dodging herds of hardy horses, and piled-up snowdrifts that were now frozen hard, we arrived at our hotel, where we assembled in a cosy dining room with a central woodfired stove. We removed our wet boots to dry by the stove, while we warmed up with lemon ginger tea. After supper (I had a Nepali thali) we retired to our rooms, which had no heating. Swaddled in woollen cap, scarf, gloves, and all my clothes, I tried to sleep fitfully, while outside the temperatures fell to $-7^{\circ} \mathrm{C}$.

In the morning through my bedroom window I was teased by the sight of a sunlit mountain peak, appearing fleetingly then disappearing in swirling clouds. We were at an elevation of $3800 \mathrm{~m} \mathrm{ASL}$, and already one of our party was suffering from altitude sickness. We wandered individually towards the great Hindu and Buddhist temples that were the objects of the pilgrimage to Muktinath. Although the surrounding mountains showed beautiful folded structures, there were no rocks to be seen-everything was still covered in thick snow. But as I slowly climbed the slippery steps towards the Hindu temple, I looked back at the town-and there rising above it, in all its glory, was the great magnificent peak of Dhaulagiri, at $8172 \mathrm{~m} \mathrm{ASL}$ the seventh highest mountain in the world, revealed fully now against a blue sky, with its gleaming glacier also visible at a lower elevation.

A giant snow-covered statue of the Buddha, in the dreamy-eyed ecstasy of Nirvana, shimmering brightly in

Manaslu, $8163 \mathrm{~m}$ ASL, 8th highest mountain in the world, made partly of Miocene leucogranites (which are not exposed on the Kali Gandaki transect).

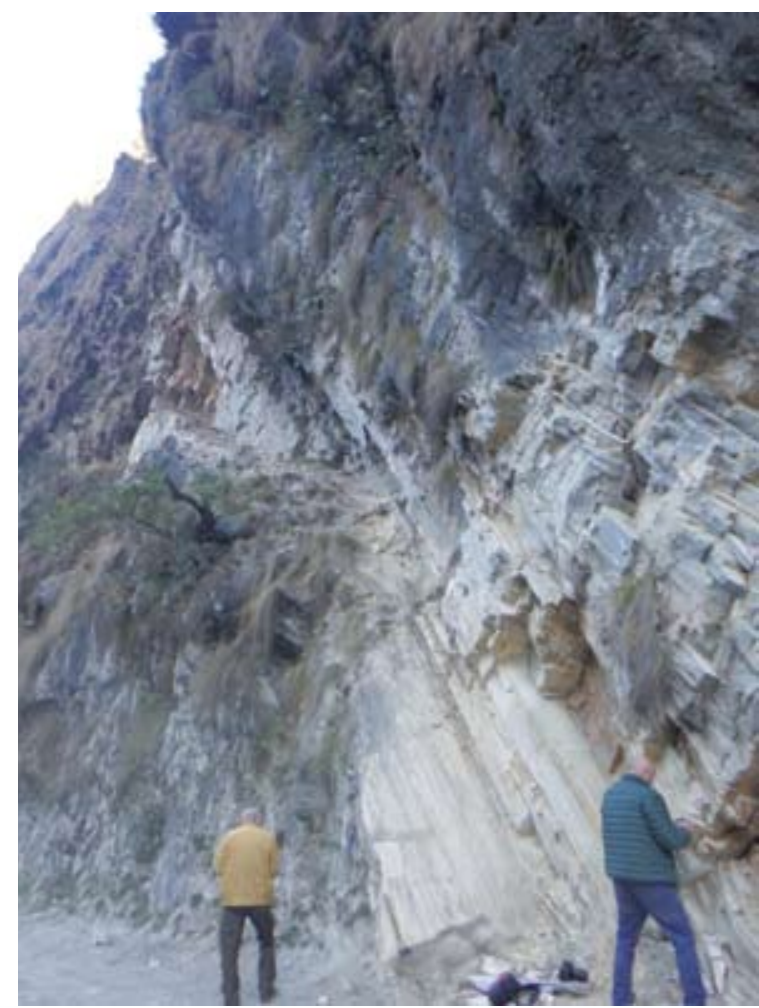

Strong down-dip mineral stretching elongation lineations along the exposed plane of north-dipping thrusts of the Main Central Thrust zone, along which the amphibolite-grade metamorphic rocks of the High Himalaya were thrust over the lower-grade rocks of the Lesser Himalaya.

the sunlight, grabbed my attention immediately. A short distance below it was an ancient Buddhist temple, with gloomy painted interior with murals, buddha statues, lama portraits, brightly coloured banners and frilly thangkas. In a small alcove there was an eternal flame, glowing faintly behind a small metal grill, fed by a leak of natural gas coming out of the Tethyan sedimentary rocks beneath the mountain. This reminded me of the Oracle of Delphi in Greece, which is also built as a sacred place above a hallucination-inducing natural gas leakage above a fault. There is an intimate connection between geology, landscape, and places of ritual and religious significance around the world.

On the way to the Hindu temple that was higher up the mountain, a group of four stretcher-bearers passed me on their way down, carrying an unfortunate old pilgrim in great distress, who had succumbed to altitude sickness. The temple is surrounded by a fountain with 108 spouts shaped like cow's heads, but the water issuing from all of them was frozen into rigid icicles. Then 


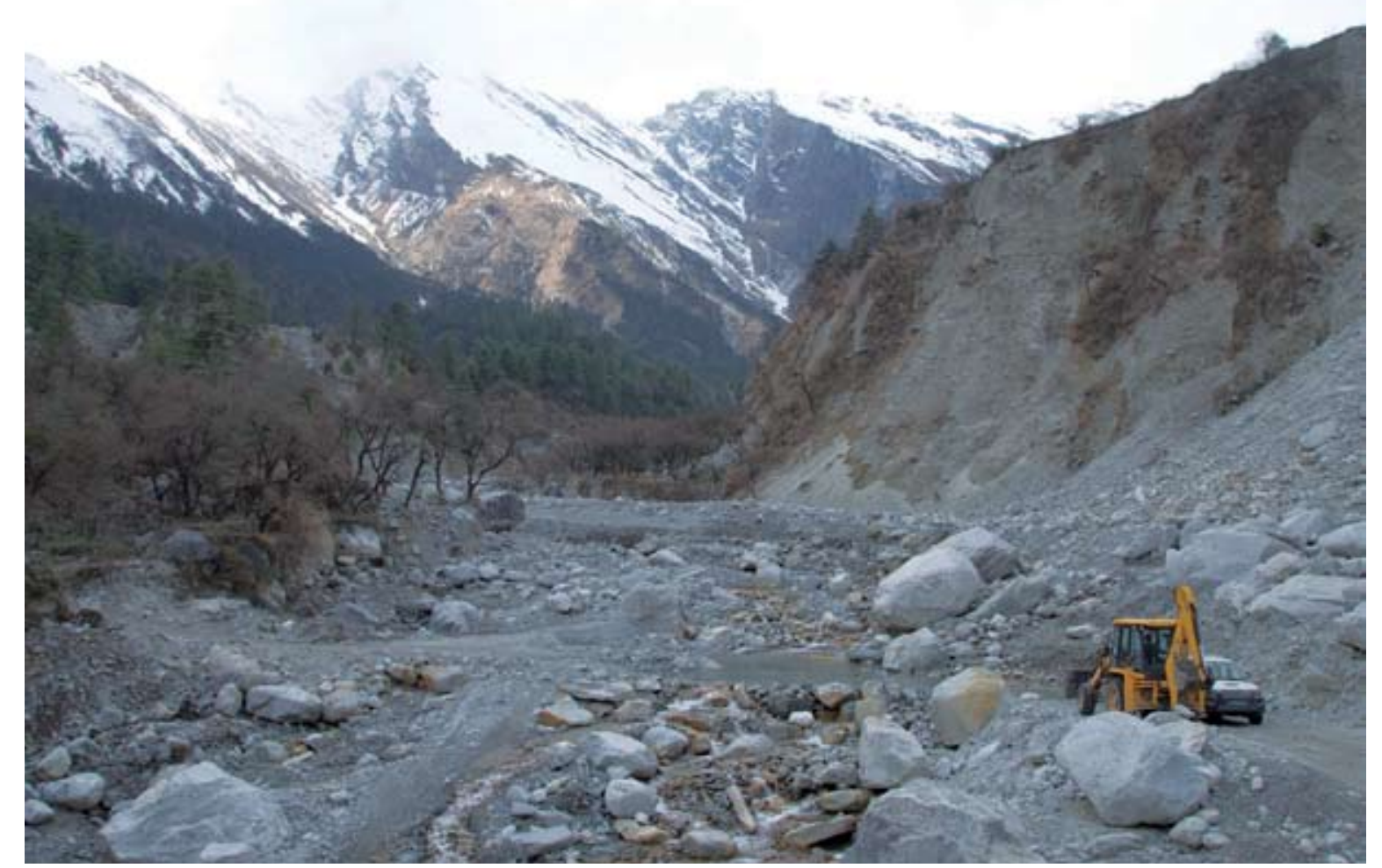

it happened-I too had altitude sickness! I recognised instantly the symptoms I had previously experienced in the Ruwenzori Mountains at an elevation $400 \mathrm{~m}$ lower than where I was now. Acute diarrhoea! Fortunately, there was a public toilet at the temple-at the highest spot I have ever been on the ground! It was a squat toilet, like all public toilets in the Indian subcontinent. And it was supplied with a bucket of water. Just a slight problem though: everything was frozen completely solid. The flattened toilet roll in one of my many jacket pockets came to the rescue! My apologies to the staff there. But ice does melt after a couple of days of warm weather! And spring, and COVID-19, was in the air!

From the sacred temples, I descended down the treacherously slippery icy steps, and was saved only by my mountaineering walking stick, which prevented me from hurtling headlong down what looked like a frozen waterfall. Near the bottom, tottering and stumbling, I finally slipped and fell. Upon seeing this, an old woman, who was sitting on the icy stone balustrade at the bottom of the steps, was so startled, she screamed and promptly fell off the edge. Fortunately she fell into snow and was unhurt, while I recovered, and found a driver with a sturdy horse sporting a colourful embroidered cloth saddle, ready to give me a ride back to my hotel for a hefty price, which I was happy to pay, instead of having to fight my way back through the thick snow.

After regrouping at the hotel, we trudged through the slush back to our vehicles below the town, before heading down towards Kagbeni for lunch. In Kagbeni I found furry baby yaks with brown and white coats tethered in backyards, while the local men were sunning themselves during a lunch break, near a chorten surrounded by a mound of stones, each inscribed with "Om mani padme hum". We had an hour to roam the town and I visited an ancient Tibetan Buddhist lamasery, which had been built in 1429. The original square brick-red building was still standing, but was earthquake damaged, with large

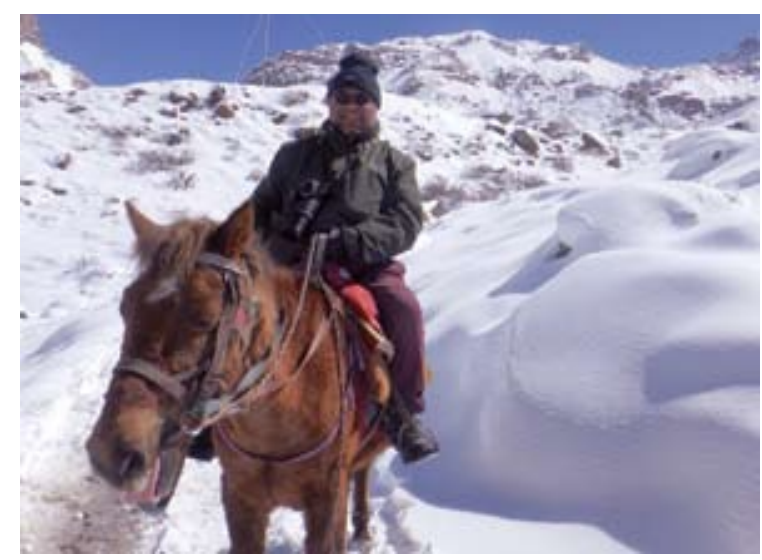

Boulders and $50 \mathrm{~m}$ high cliffs on the right constituting the terminal moraine of the Dhaulagiri Glacier.
Descent from the Muktinath temples back into town - the easy way, on horseback! 
Tibetan lamasery at Kagbeni. The original square building, on the right, was built in 1429 $C E$, and has suffered earthquake damage (large vertical cracks on the façade).

Looking north along the Kali Gandaki gorge at its narrowest. It is so narrow (just a few metres

wide), that the cliff had to be undercut to accommodate the road. The river runs towards the observer through an even narrower vertical gorge between the road and the cliff on the left.

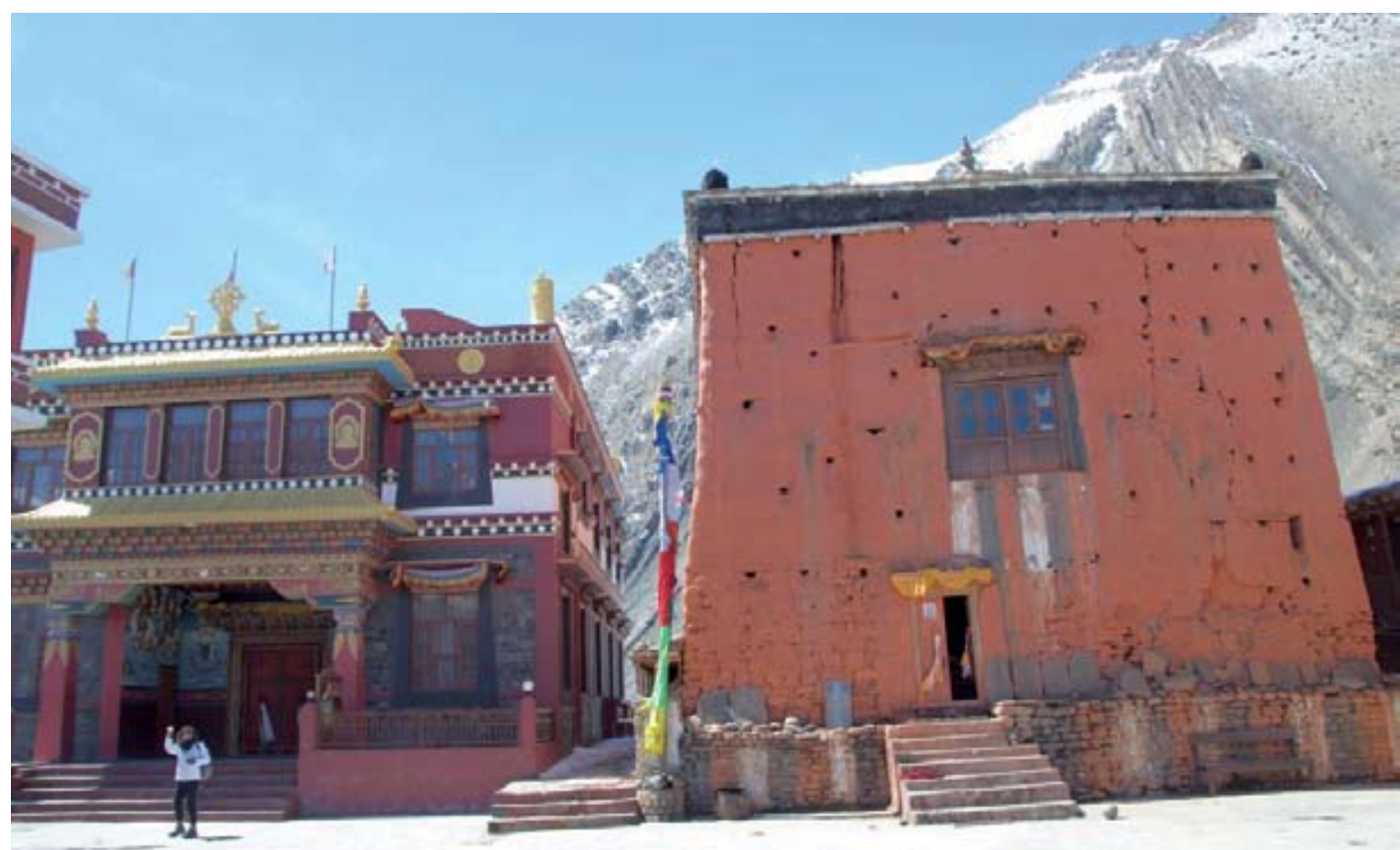

cracks in the walls. Its interior was made of wood, with murals and ancient painted sculptures. A young Buddhist acolyte tried, not very successfully, to explain to me the intricacies of his faith, which involved many cycles of birth, reincarnation, and manifestations of the Buddha. I had a moment of realisation there-that the worlds of science and religion are two parallel universes! We had tasty

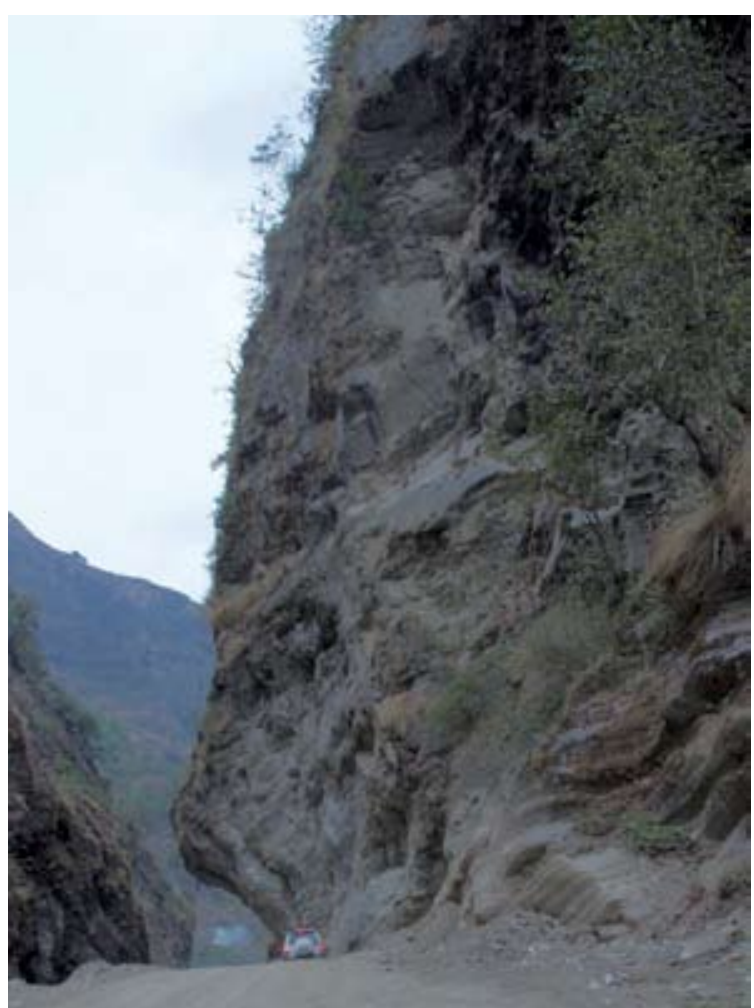

yak burgers at a restaurant called Yak Donalds, run by a Tibetan family. Then we headed down the Kali Gandaki gorge once again, past the spectacular Thakkola folded cliff sections, and ran into another roadblock caused by a major landslide between Lete and Ghasa. During the hour and a half it took while bulldozers cleared the road, we were able to examine fresh exposures of amphiboleand titanite-bearing metamorphic veins in the Crystalline High Himalayan rocks. The sun had long set when we eventually reached Tatopani, where we spent the night.

The next day we departed early and stopped near the Kali Gandaki-Modi Khola confluence at Kushma, where we crossed the Kushma-Balewa bridge, a swaying highly elevated suspension footbridge (117 $\mathrm{m}$ high, spanning a length of $347 \mathrm{~m}$ ), from which we had terrific views of the Kali Gandaki river and its terraces, as well as the northwestern face of Machhapuchhare, which really does resemble a fishtail from this side. We reached Pokhara in the late afternoon, which gave us time to visit the shops. I purchased maps, souvenirs, and Nepalese minerals, in the form of crystals of tsilaisite (a dark yellow form of tourmaline). This was the end of our excursion, and we had a farewell dinner at a beautifully decorated Nepali restaurant. 


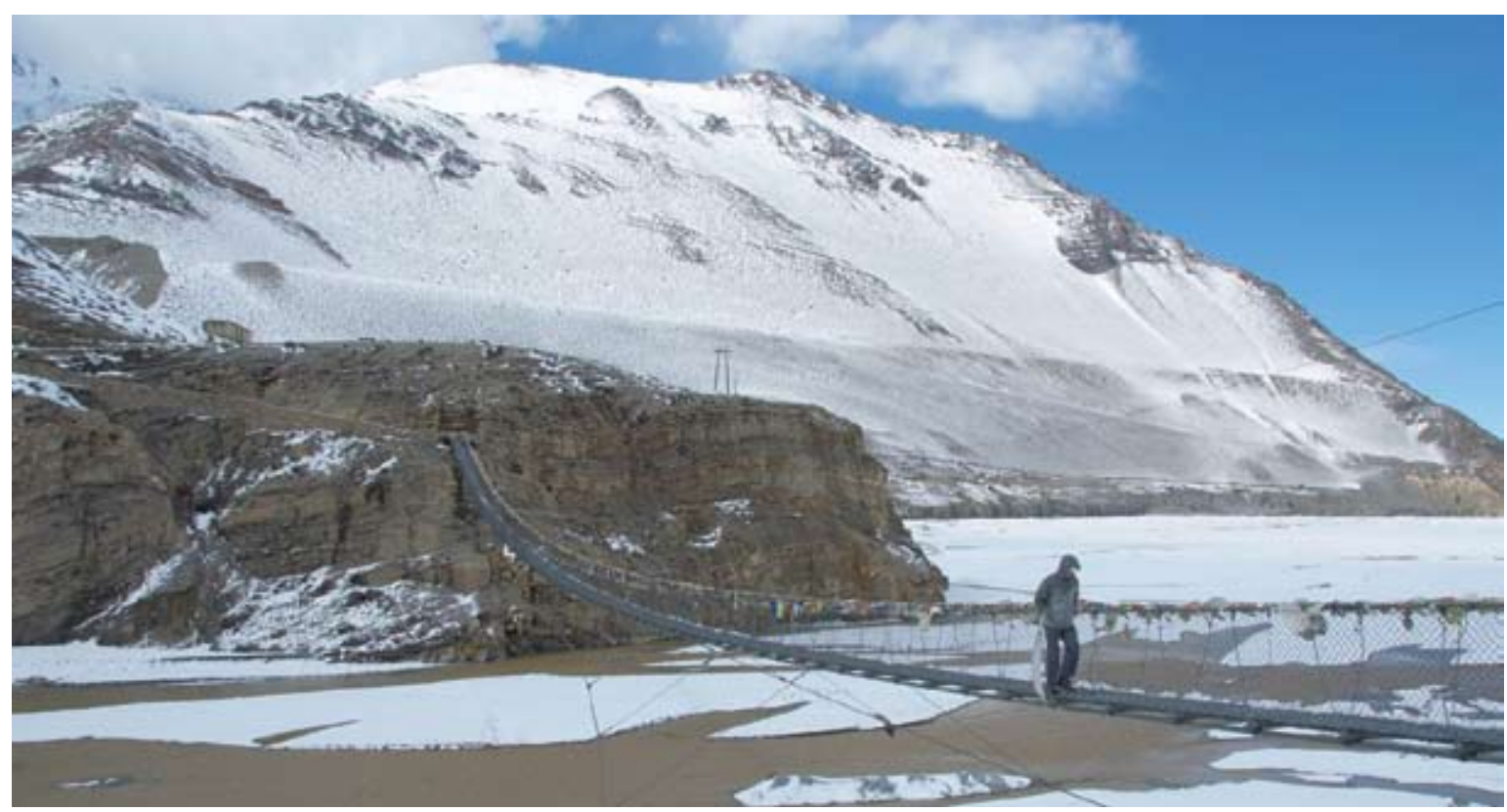

Snow-covered

conglomeratic braid bars on the Kali Gandaki River, and suspension bridge at Eklebhatti, at about $2740 \mathrm{~m}$ elevation.

At five o'clock the next morning I departed with our tour leaders, who were heading back to Kathmandu. After following the gorges of the Seti and Marsyangdi rivers, we stopped for a traditional Nepali breakfast of dhal and puri at Mugling. We then followed the Trishuli River for part of the way to Kathmandu. After arriving at my hotel in the early afternoon, I walked into the old city, still reconstructing after the devastating M7.8 Gorkha earthquake of 25 April 2015, in which more than 9000 people died. I tracked down the restaurant that offered Kathmandu's best Momo (filled steamed Nepali dumplings). Next door I found a travel agency advertising flights over the Himalaya. I popped in out of curiosity, and emerged with a ticket for a flight on the “Everest Express"!

Early the next morning, having taken a taxi to the airport, I found that three of my colleagues on the field excursion also had the same idea, and had booked for the ultimate geological Peak Experience! We boarded the Yeti Airlines plane, which was a turboprop, which meant the visibility was not optimal-one sometimes had to see through the propellers! Although it was a short flight, we got to see six eight-thousanders—Everest (8848 m ASL), Kangchenjunga

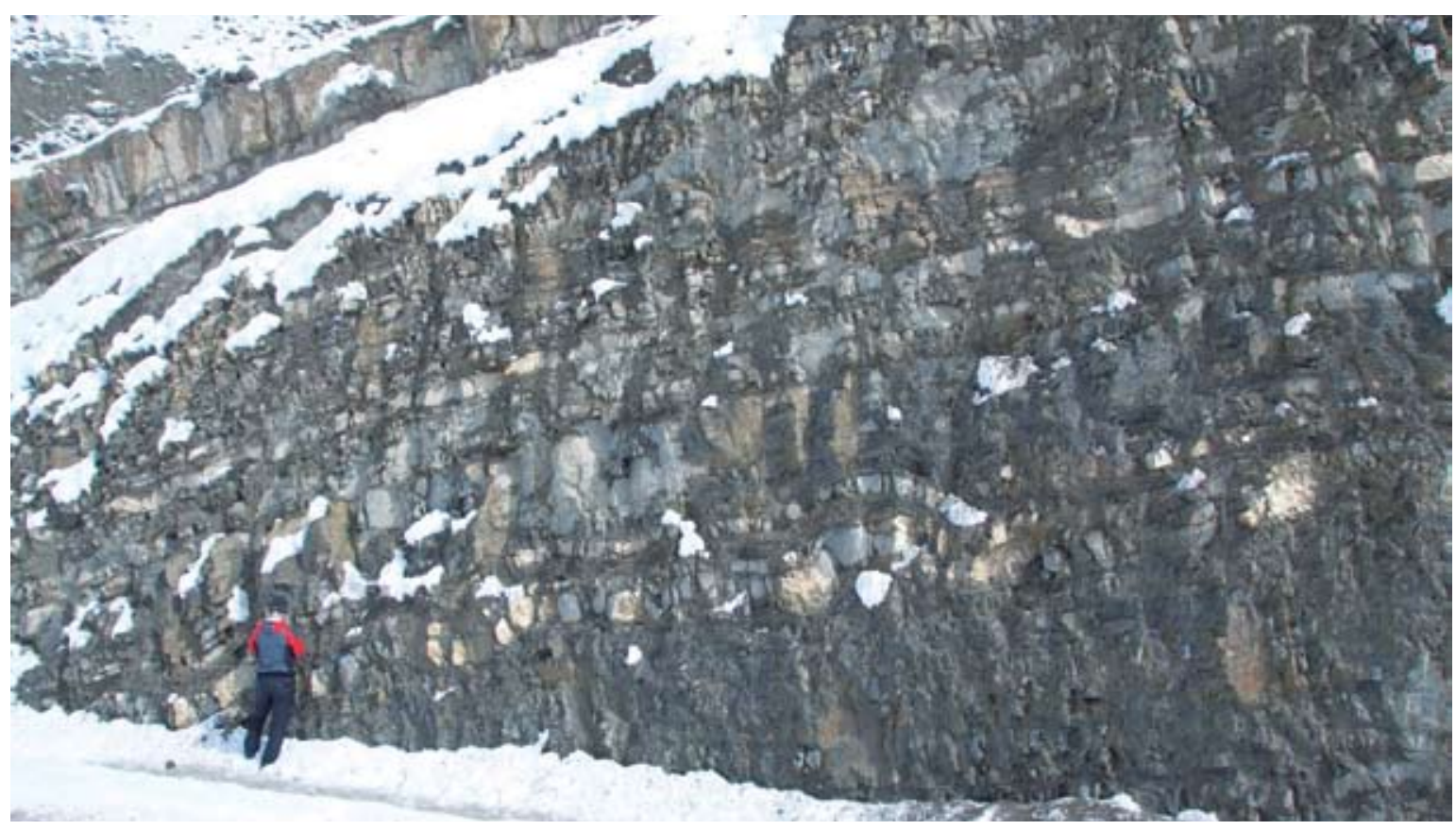

Middle Jurassic marine Tethyan limestones near Eklebhatti, Kali Gandaki River east bank. 


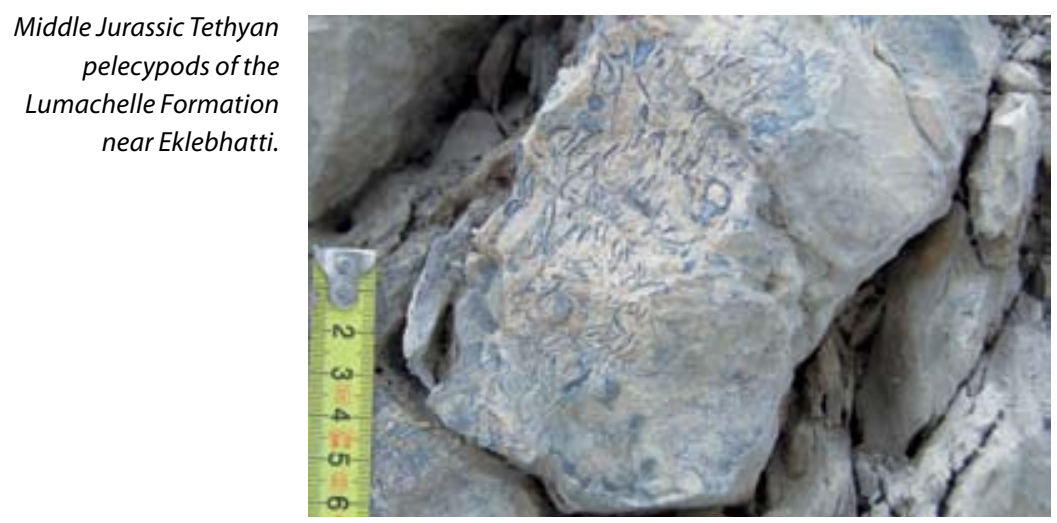

(8586 m), Lhotse (8516 m), Makalu (8463 m), Cho-Oyu (8201

m) (all on the Nepal-Tibet border), and Shisha Pangma (8013

m) (entirely in Tibet) - as well as many other mountains and glaciers. Together these comprise the greatest and loftiest mountain landscape on Planet Earth-the Himalaya, abode of the Gods.

The next day was to be my last full day in Kathmandu, and I had planned a day of sightseeing. My travel agent had booked me a flight for the following day to Johannesburg via Istanbul, with Turkish airlines. After breakfast the receptionist asked me if I had heard the news. What news? What he told me nearly gave me a heart attack! Nepal was closing its borders, and all Nepalese wanting to return to the country had to do so before midnight on that same day! And what about leaving the country? He was not sure. I immediately tried to get hold of my airline and there was no reply, either from the city office, or from the airport. There was a flight that same afternoon, but there were only 3 hours to go! If I wanted to be on that flight, I had to go immediately to the airport, and try my luck! In full panic mode, I ordered a taxi, ran up to my room, packed up everything in five minutes, hurried back down with my luggage, and was about to

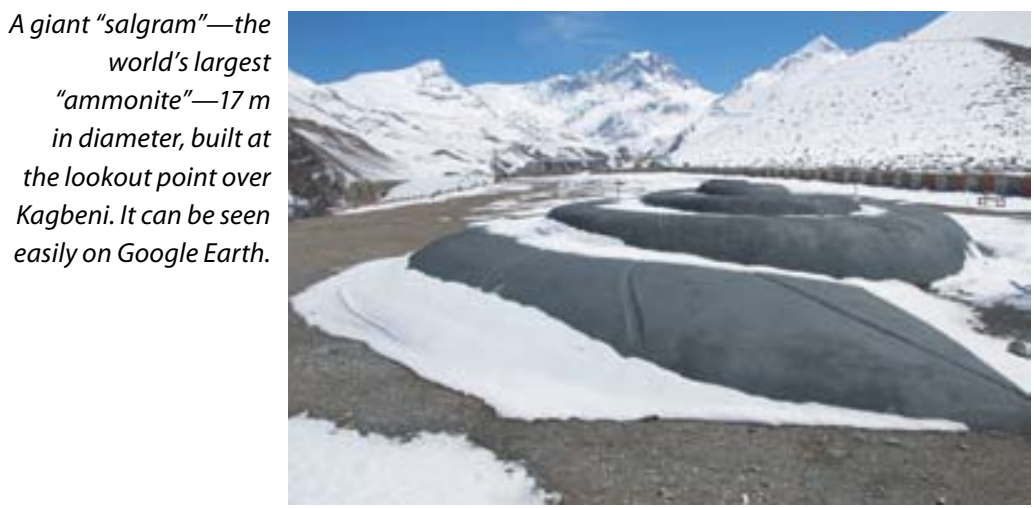

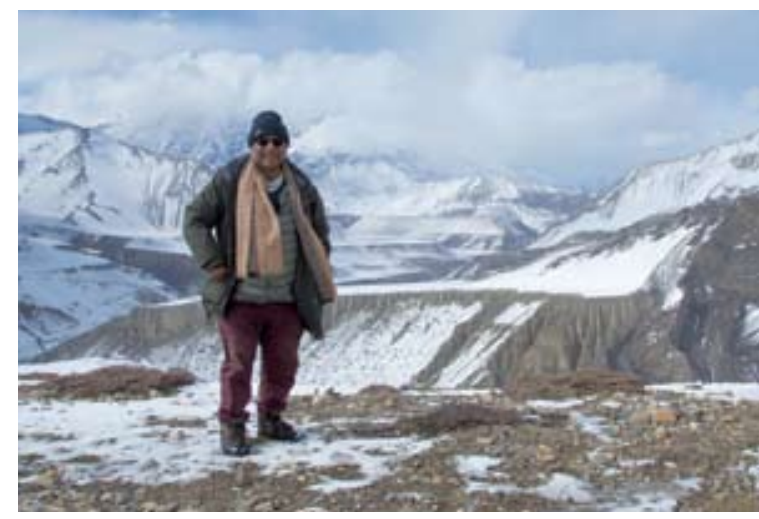

At the frontier of Mustang, which borders on Tibet. In the background are deeply gullied and eroded Quaternary sediments of the Thakkola Graben. Note the GSSA hat!

enter the taxi, when the receptionist called me, saying he had got Turkish Airlines on the phone. To my greatest relief, they informed me that my flight the next day was still on, and that my place on it was confirmed. But they could not confirm my onward flight from Istanbul to Johannesburg.

I spent the rest of the day at the great Buddhist temple of Kathmandu, the Boudhanath Stupa-a World Heritage site-with its great white dome and golden pyramidal spire, festooned with fluttering prayer flags. Later I went into the Durbar Square in the heart of Old Kathmandu, an area that was badly damaged during the 2015 earthquake, and which was now being reconstructed with international help. Since all foreigners were leaving the next day, I found myself as the last customer for many of the curio sellers in Durbar Square. One of them persuaded me to visit his shop, where there were many interesting things-old illuminated Tibetan Buddhist manuscripts, Tibetan dZi beads, Yak-skin masks—relicts

Boudhinath Stupa in the heart of Kathmandu - the largest Buddhist stupa in Nepal.

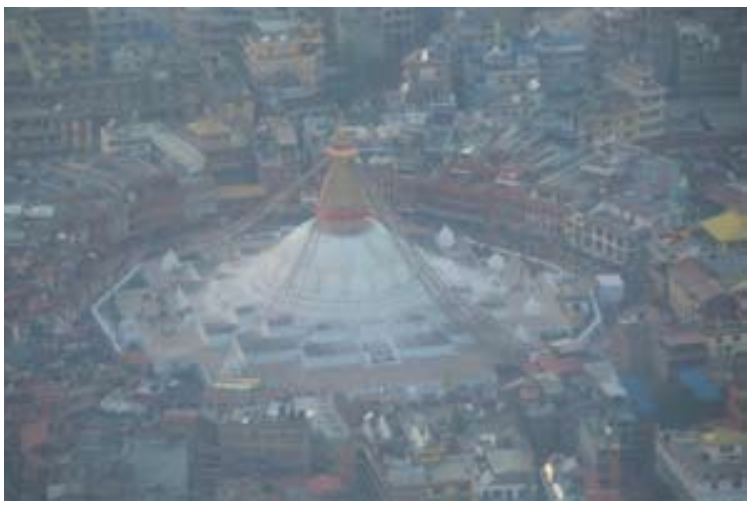




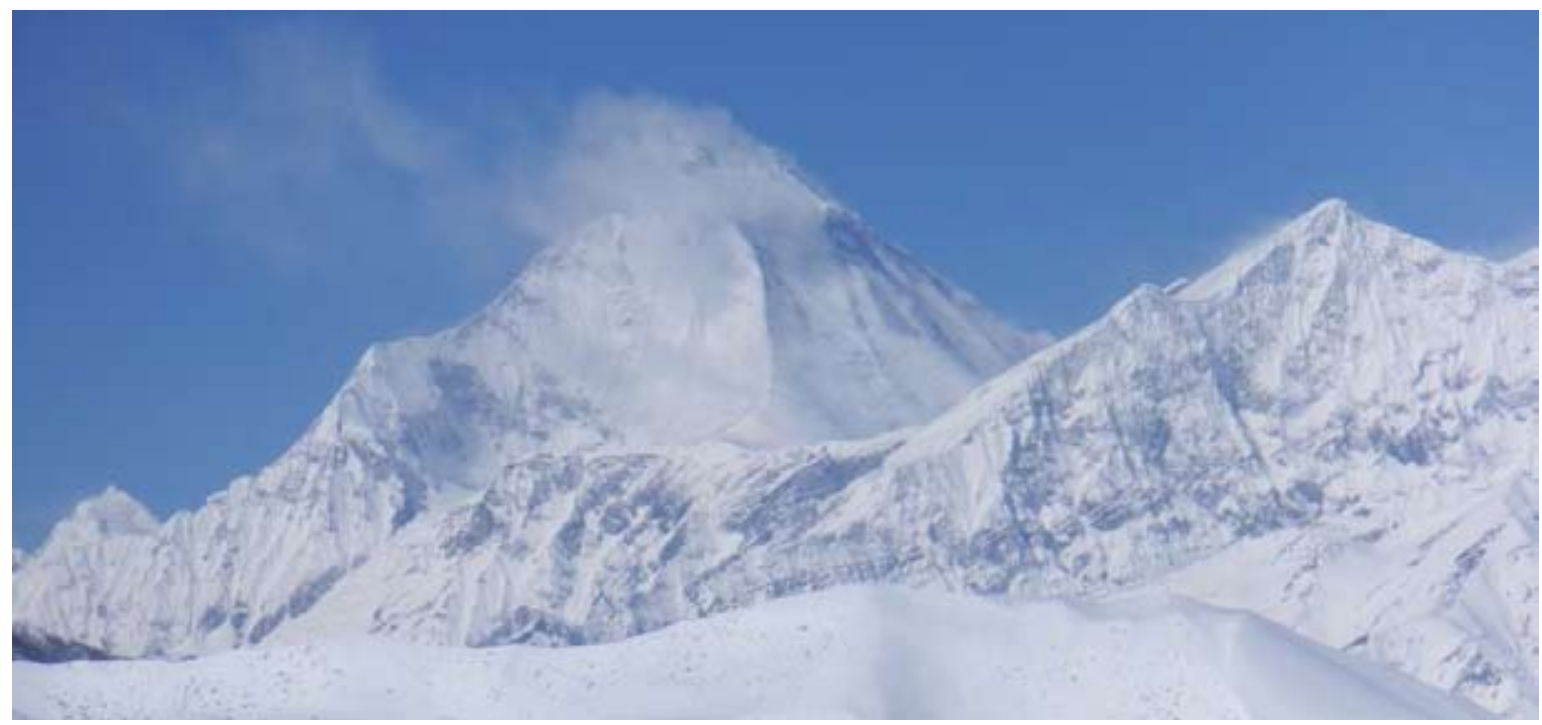

Clouds blowing off the summit of Dhaulagiri, the $7^{\text {th }}$ highest mountain the world (8167 $\mathrm{m} \mathrm{ASL}$ ). Part of the Dhaulagiri Glacier is visible just left of the rocky ridge directly below Dhaulagiri. In the foreground are the snowcovered hills at Muktinath

of a culture that was being destroyed by the very same restorers of Kathmandu. Then he took me to his friend's shop in an alley around the corner-and he had a Tibetan Buddhist bowl, made from a human skull, lined with silver and embellished with stylised skull decorations. I shuddered as I handled this skull-you could clearly see the sutures in it. The Tibetans are well known for their stoical approach to death, as evidenced in their "Sky burials". I had Thukpa (a Tibetan noodle soup) for supper at a restaurant in Freak Street (1970s abode of Western hippies). I wandered around the ruined buildings of Old Kathmandu at night. Some of the buildings were teetering close to collapse, propped up by flimsy logs; others were covered in scaffolding. But the night was busy with people doing shopping for food and clothes. Already, many people were wearing masks. Worrying news was spreading of the epidemic emanating from China, and although very few cases of COVID-19 had been reported in Nepal, the borders were closing.

The next morning I found the airport in a state of pandemonium. Every foreigner in the country was flying out, there were long queues and tempers were fraying. I checked in, then joined the immigration queue. As I was getting my passport stamped, I heard my name calledthe Immigration Official told me to go back to check-in, to where the bags are X-Rayed. The official there wanted to know what I had in my bags. I told him they were rock samples. He wanted to know where my export permit was. At this point I would have been ready to throw a Trumpian tantrum, but being a seasoned traveller, I calmly persuaded him that I had collected them in India (which was not incorrect), and I showed him a fossil with the name of the Birbal Sahni Institute that had presented it to me. He was satisfied. This is the sixth time something like this has happened to me, and it did not always end so well (the score so far: Science 4, Customs Officers 2). It is a professional occupational hazard of an academic geologist!

My day flight to Istanbul was really interesting. We flew over the Terai of western Nepal, then over the IndoGangetic plain in north India, then over the valley of the braided Indus River, and northern Kirthar Range, in Pakistan, across the Dasht-i-Margo desert on the Helmand Block of Afghanistan south of Kandahar, then across the Dasht e-Kavir salt lakes and the Elburz Mountains of northern Iran, and Lake Van and the snow-covered Anatolian Plateau of Turkey. We landed at Istanbul's new airport, which is $2 \mathrm{~km}$ long. The airport was eerily

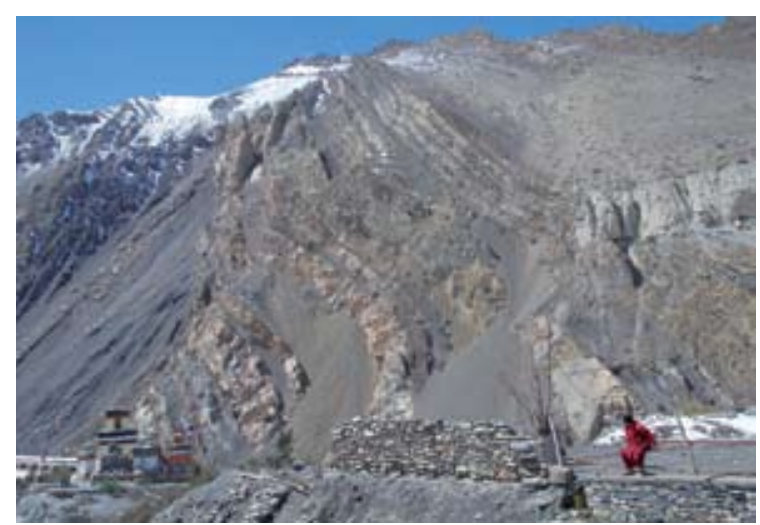

Folded Tethyan sedimentary rocks behind the Tibetan Buddhist lamasery at Kagbeni. 
East face of

Machhapuchhare showing the doublepeak which gives it its name, which means "Fishtail", viewed from the Kushma-Balewa bridge over the Kali Gandaki.

The Top of the Worldand the highpoint of my field trip-on the border between Nepal and Tibet. The triangular peak is Mount Everest, highest mountain on Earth, at $8848 \mathrm{~m}$ ASL. The second highest peak in the image, to the right of Everest, is Lhotse $18514 \mathrm{~m}$ ASL), the fourth highest mountain the world. On the left is the flat ridge of Nuptse (7861 m ASL).

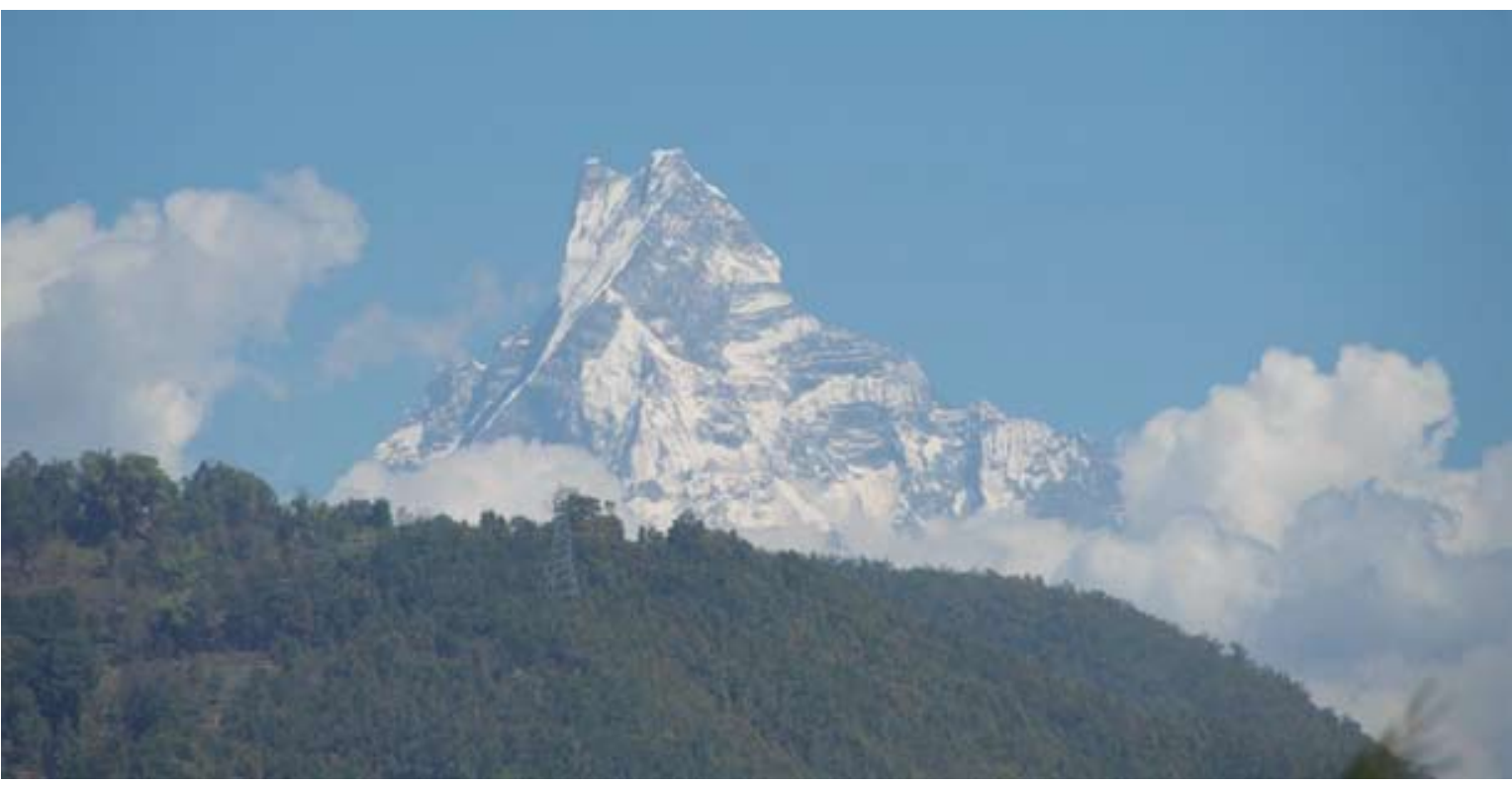

deserted. I walked for a $\mathrm{km}$ without meeting any other people. When I looked at the departure boards, almost every flight to the 150 destinations served by Turkish Air was shown as having been cancelled. Among the very few flights still on schedule was the one to Johannesburg (to my intense relief).

Upon arrival in Johannesburg, I found that there were only South Africans on board, on the last flight out of Istanbul. Two days after my arrival home (I was already in a 14-day quarantine), the Level 5 lockdowns were announced. I have been in solitary isolation for the past eight months-and the world of geological field trips and traipsing around exotic countries seems like a dream now, in a different universe. If I wake up to discover that my trip to Nepal was just an elaborate dream-well, what a dream that was!

\section{Sharad Master}

EGRI, School of Geosciences,

University of the Witwatersrand,

Johannesburg 
The Department of Earth Sciences at Stellenbosch University,

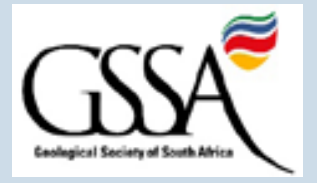

the Geological Society of South Africa,

the Igneous and Metamorphic Studies Group, and

the Global State of Affairs

regret to announce:

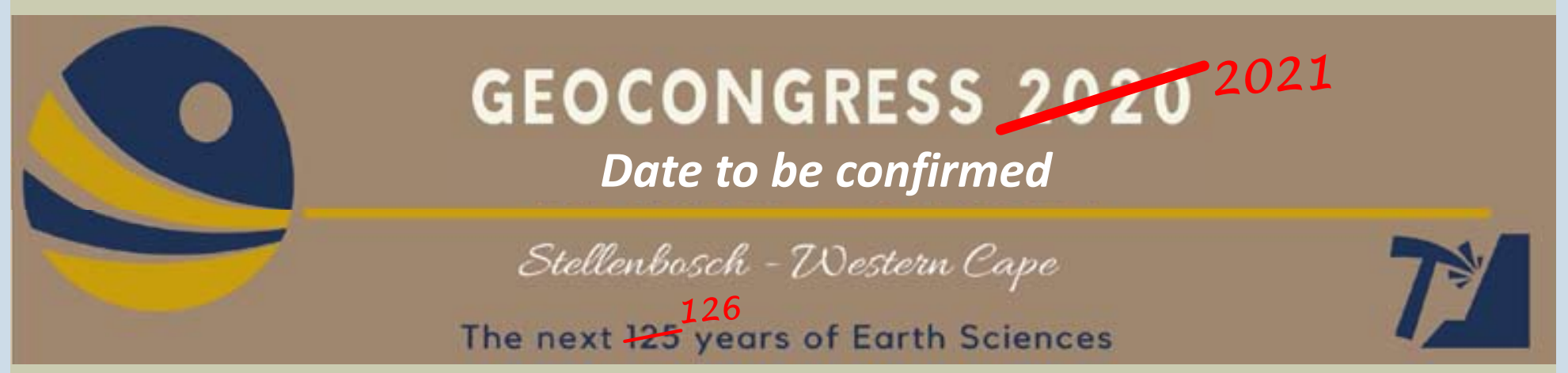

\section{EVENT POSTPONED}

Dear Southern African Earth Sciences community,

As many of you by now well know, the current global Covid-19 pandemic, which grips the world in its virulent claws, has led the Geocongress Local Organising Committee (LOC) to make the difficult (but we believe correct) decision to postpone the 2020 Geocongress. The committee continues to monitor the local and international situations, and has as yet not made a definite decision regarding the exact dates over which the postponed Geocongress will be held. Our preliminary feeling is that the event will run in June/July 2021 and that it will comprise a significant component of online or remote-access functionality.

The LOC would like to apologise for any inconveniences that this postponement may have caused, and would like to thank each and every one of the session chairs for their efforts thus far. At this point, the theme and proposed sessions will carry over to next year, the website will remain live, and the abstract submission portal will continue to accept abstracts. The event website (http://allevents.co.za/ geocongress/), the Geobulletin, and the GSSA mailing list will remain the primary vehicles for communication of updates related to the postponed Geocongress. As always, we will look forward to welcoming everyone to Stellenbosch once it is safe to do so. 


\section{geoheritage report}

During September, Heritage Month in South Africa, the Geoheritage Division of the GSSA arranged a series of lunchtime lectures, most of which are available for viewing on the GSSA website: www.gssa.org.za. The message emerging from these talks is that South Africa has an extraordinary, but undervalued, geoheritage. October saw the first of the monthly geoheritage talks that are to become a regular feature in the GSSA lunchtime lecture calendar. Again, the issue of bringing geoheritage to a wider audience emerged as a major challenge, and the solution proposed is to begin with the scenery. In his talk, Roger Scoon related the topography in the eastern Bushveld Complex to the Middleveld, a

a

useful term for the terrane between the Highveld and the Lowveld. From the land surfaces of the interior we turn next to the raised beaches of the coastal platforms. The complete sequence of raised beaches is preserved in the magnificent scenery of the Wild Coast, so this area could be the focal point where travellers are introduced first to the scenery of South Africa, then to the superlative geology that underpins this scenery. To explore this potential, the merits of a Wild Coast Geopark or World Heritage Site will be the topic for the geoheritage lunchtime lecture in the last Wednesday of February 2021.

\section{Chris Hatton}

GSSA Geoheritage Division

Raised beaches at Pennington, preserved on resistant Natal Group sandstone (foreground)
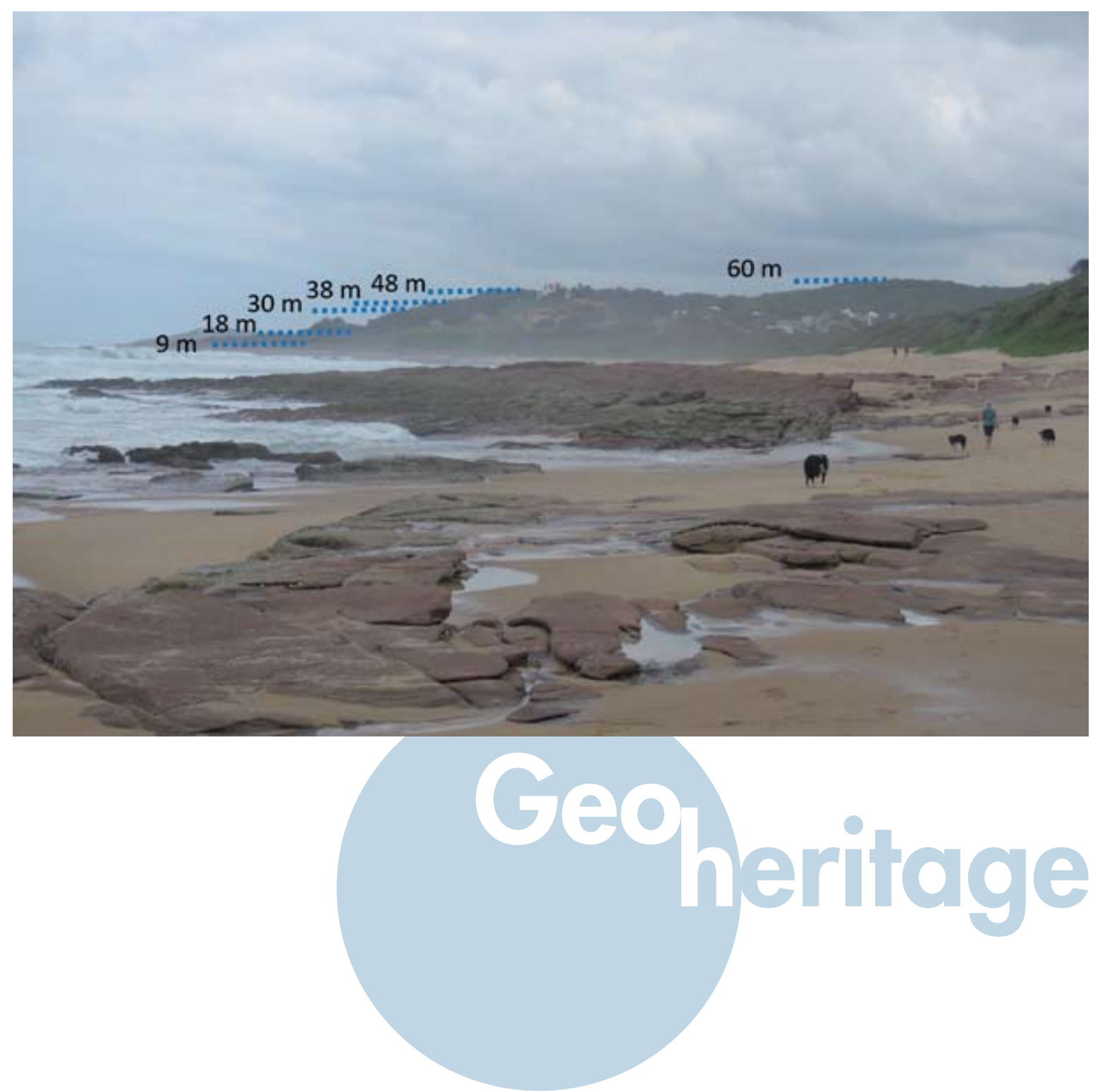


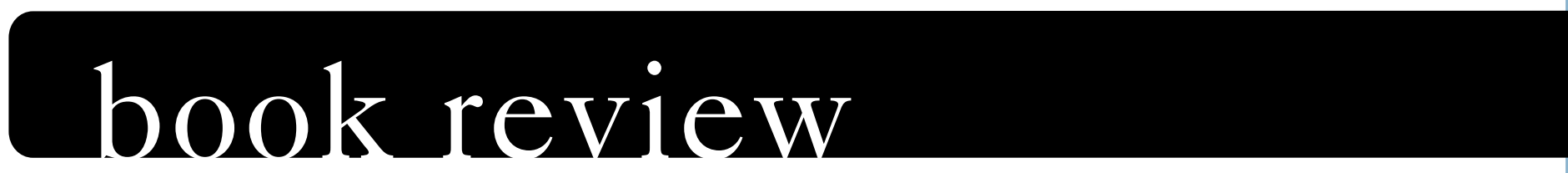

\section{'Going to Ground' by Nick Norman}

Going to Ground, the autobiography of Nick Normanwell known to readers of Geobulletin as the co-author of Geological Journeys, a landmark publication in the popularisation of South African geology-is an entertainingaccount of thelifeofanexplorationgeologist. The opening chapter introduces the experienced consultant on assignment in Mauritania, able to quickly assess whether the client is indeed in elephant country. The subsequent chapters trace his early life at schools in KZN where connections that are to prove invaluable in later life are forged, following on to University, then to employment and consulting, which takes him to fascinating destinations in the early days of exploration throughout Africa and South America. Exploration for base metals and diamonds in Botswana, Namibia and Brazil intertwines with the romantic excursions of a young geologist who then settles down in Franschhoek and starts life as a farmer. While subsidising a farmer's income with consulting on the potential site of nuclear power stations in the Eastern Cape, he meets his future wife whom he takes to Chile where their children are born. Return to South Africa coincides with the miracle days of the transition to democracy. After subsequent excursions into Africa, where the attractiveness of the country corresponds roughly with the beauty of its birdlife, he combines his experiences with a map-based Chilean travel guide and a similarly map-based South African bird guide to create the format for Geological Journeys, co-authored with Gavin Whitfield. The success of this book leads on to the writing of the Extraordinary World of Diamonds, Off the Beaten Track and, for young readers, Box of Rocks.

Filled with anecdotes and glimpses of the characters who led geological exploration in the late twentieth century, this book will appeal not only to geologists,

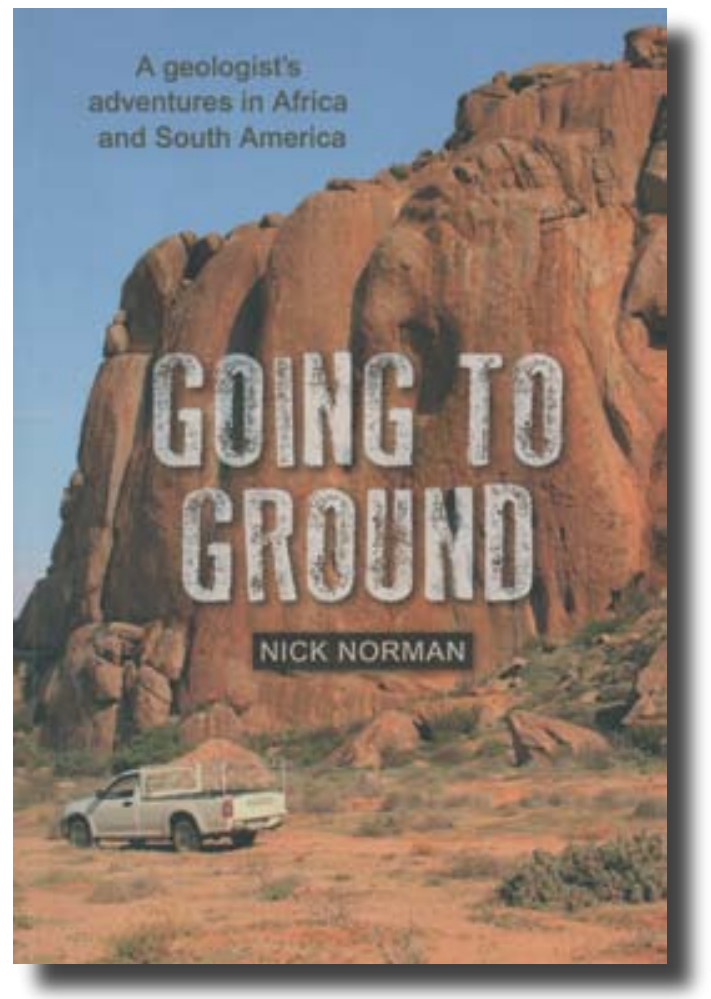

but to all those with a love of the outdoors. In particular the tapestry of rocks, birds and plants captures "the mysterious hold that Africa has on her inhabitants". Aspirant writers will learn of the challenges associated both with traditional publication, where the support of institutions such as the CGS and De Beers proved vital, and of self-publication, the route followed for Going to Ground. The release of this book coincides with the seismic shift to a world grappling with coronavirus, so it will always stand as a nostalgic look back to the safer world we used to know.

There are three ways one could order Going to Ground: from major booksellers like Exclusive Books or Bargain Books who, if they don't have it in stock, will order it (sale price R320); from Takealot, by following the link https:// www.takealot.com/going-to-ground/PLID70534071; or by ordering directly from Nick Norman (nnorman44@ outlook.com) if you would like more than one copy.

\section{Reviewed by Chris Hatton}




\section{mineral scene}

Transvaal Jade / Grossular (variety hibschite) garnet from the Bushveld Complex

\section{Bruce Cairncross}

Department of Geology, University of Johannesburg brucec@uj.ac.za

The Bushveld Complex is well known for various reasons: its size, the resources of chromite and PGEs and several other mineral deposits, and as a source of dimension stone. Perhaps less well known, and less abundant, is the presence of "Transvaal jade", a colourful solid material that has been known to lapidarists, jewellers and gemologists for decades. "Transvaal jade" is a misnomer and the name has undergone various iterations over time, including "hydrogrossular garnet", that is, grossular with part of the orthosilicate ions replaced by hydroxide ions, which is essentially the same as hibschite $\mathrm{Ca}_{3} \mathrm{Al}_{2}\left(\mathrm{SiO}_{4}\right)_{3-x}(\mathrm{OH})_{4 x^{\prime}}$ a variety of grossular.' Hibschite is now no longer an IMA approved species but rather considered an informal intermediate composition within the Grossular-Katotite Series $\left(\mathrm{Ca}_{3} \mathrm{Al}_{2}\left(\mathrm{SiO}_{4}\right)_{3}\right.$ to $\left.\mathrm{Ca}_{3} \mathrm{Al}_{2}\left[\square(\mathrm{OH})_{4}\right]_{3}\right)$. The "Transvaal jade" label came about due to the green varieties of the hibschite resembling that of oriental jade. Apart from hibschite, associated minerals include clinozoisite, prehnite, pumpellyite, thomsonite and vesuvianite. ${ }^{2}$

About 100 years ago in 1920, outcrops of what was thought to be jade were found on the farms Buffelsfontein $465 \mathrm{JQ}$ and Turffontein $462 \mathrm{JQ}$ in the Rustenburg district, close to the boundary between Rustenburg and Brits, approximately $70 \mathrm{~km}$ west of Pretoria. ${ }^{3,4}$ The hibschite
A $14.2 \mathrm{~cm}$ polished slice of layered green hibschite between black chromite layers. Rustenburg district.

(Specimen and photo: Bruce (airncross).

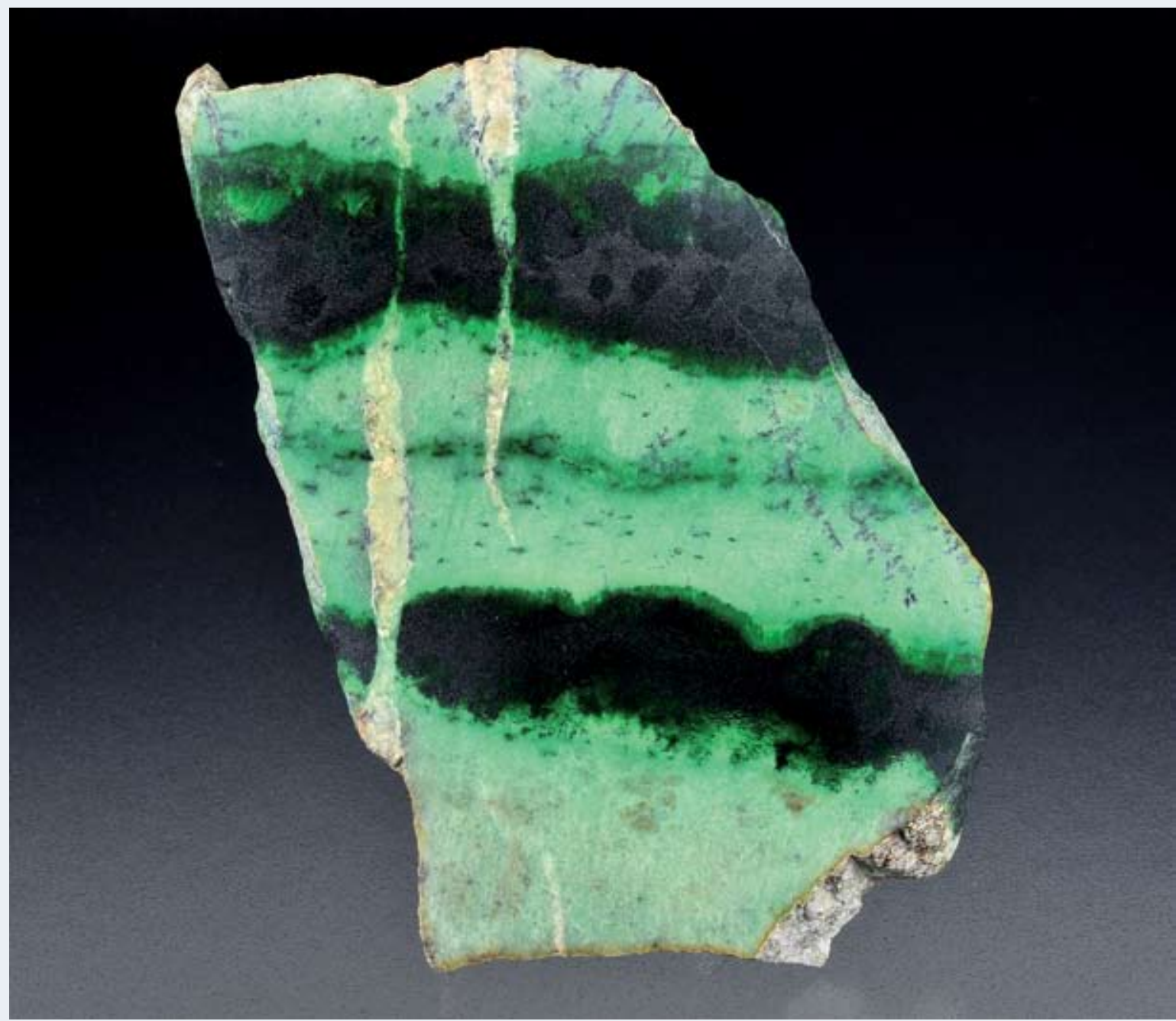




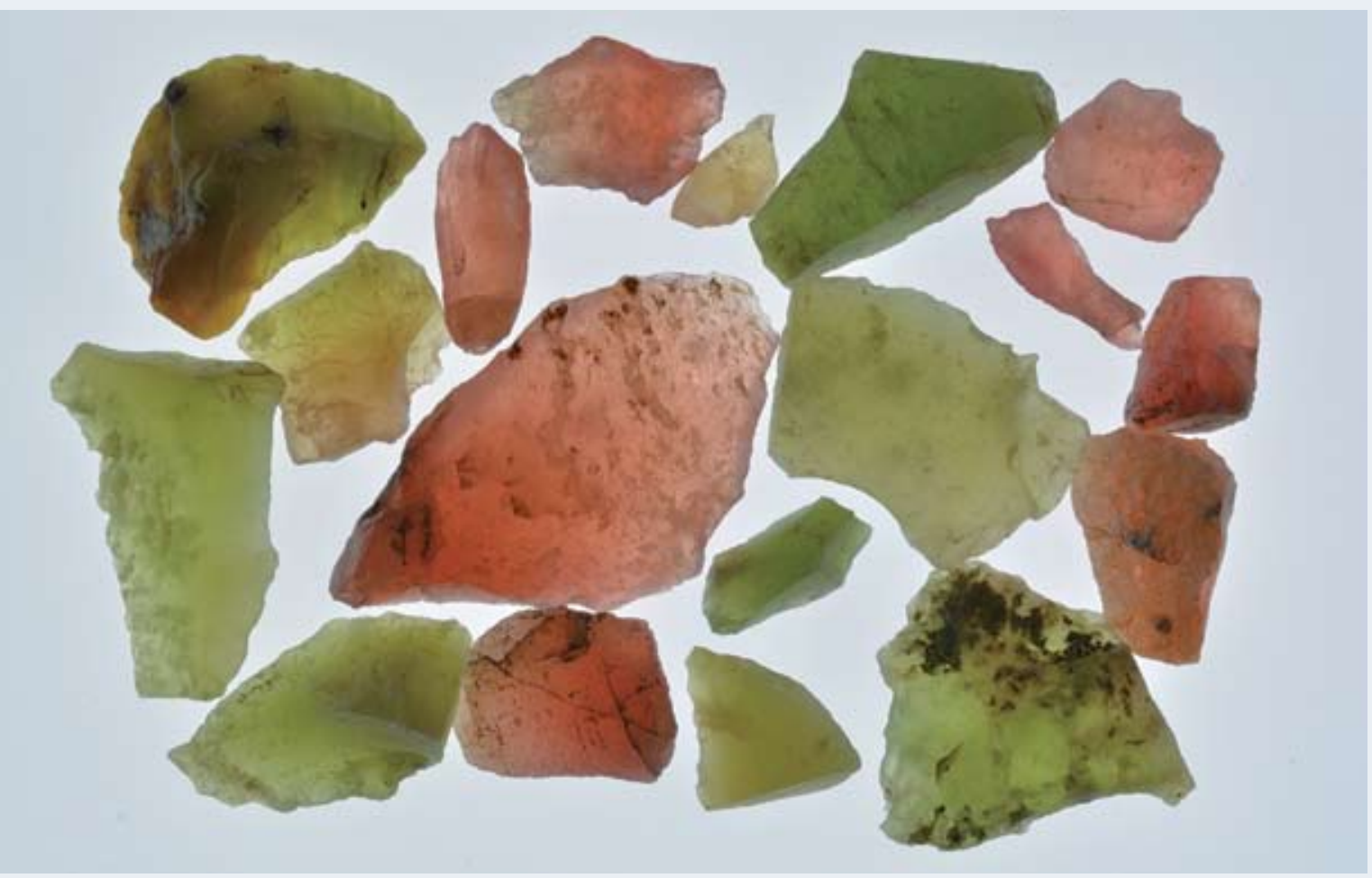

Various hibschite specimens prior to polishing, backlit to show their translucency and transparency. Large piece is $4 \mathrm{~cm}$. (Specimens and photo: Bruce (airncross).

was originally described as being hosted in Bushveld Complex norite, ${ }^{3}$ but later investigations describe its presence in anorthosite and pyroxenite near the top of the Upper Zone in the Western Limb. ${ }^{2}$ The "jade" was discovered in close association with chromite ore and was quarried as a commercial, ornamental stone by South African Jades Limited, who marketed the stone as South African jade. The "jade"-bearing zone varies markedly in thickness from microscopically thin laminae to $50 \mathrm{~cm}$ and more, and is frequently closely associated with chromitite seams.

The physical features of the hibschite make it ideal to use as a lapidary stone in carvings, cabochons and other jewellery items. The material is very homogeneous, translucent to transparent, displays a very even texture

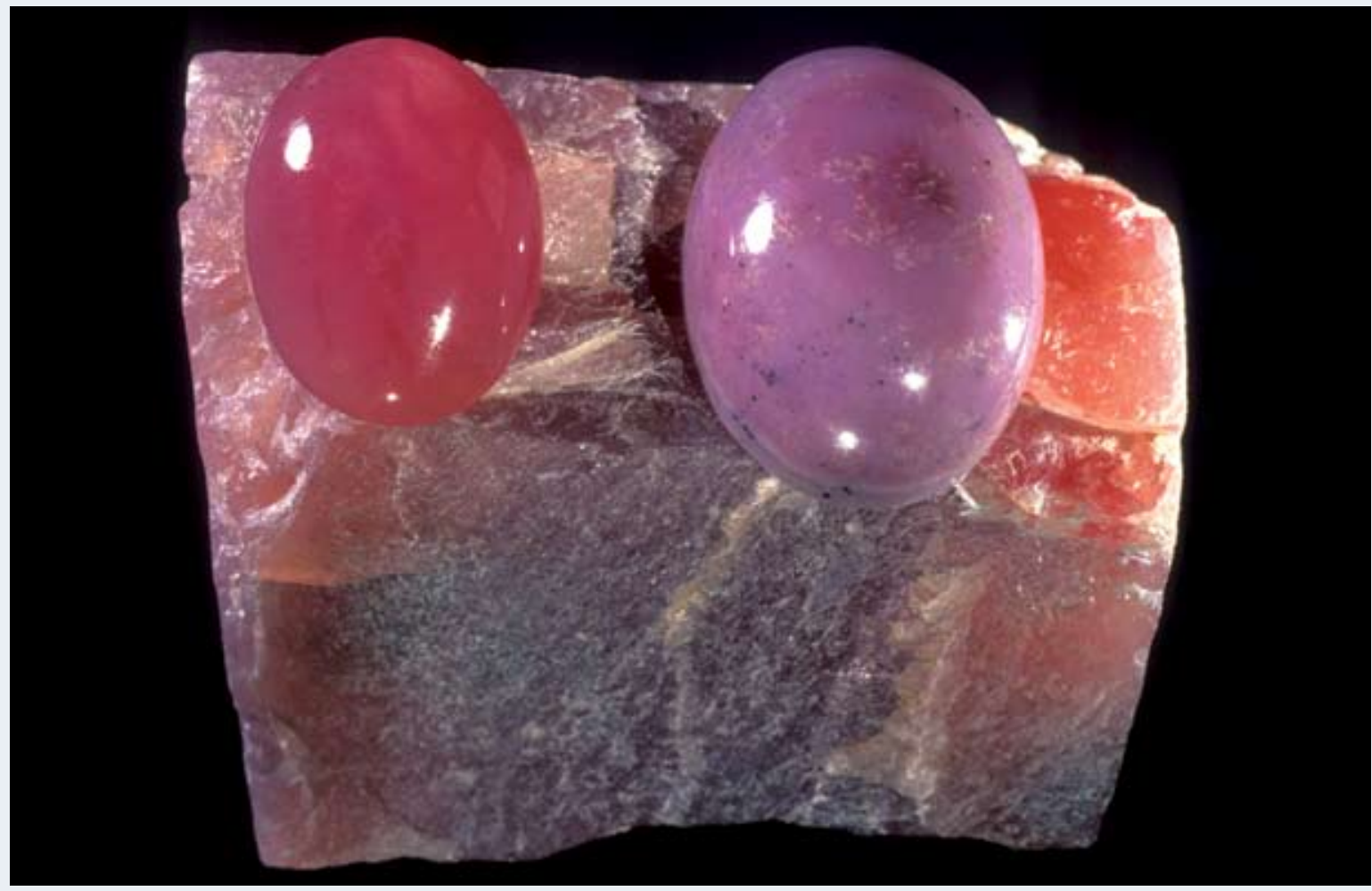

Rough pink-red

hibschite, $6 \mathrm{~cm}$, with two polished cabochons, one made from translucent pink material, the other from opaque light purple. (Specimen: Eric Farqharson; photo: Bruce Cairncross). 
and polishes well. A wide spectrum of colours occurs, including various shades of translucent to opaque green, light to dark pink and cream. Green, and varieties thereof, is the most common colour. Dark green and pink-red varieties are the most desirable, whereas the white-grey material has little commercial value. The deep pink to red colouration is caused by the presence of $\mathrm{Mn}^{2+}$ ions in the hydrogrossular structure. Page $^{2}$ analysed the bright pink hibschite and found $1.8 \mathrm{wt}$. \% MnO. The bright green variety results from the presence of chromium, with $\mathrm{Cr}^{3+}$ in octahedral coordination. ${ }^{5}$

The hibschite is believed to have formed from the alteration of plagioclase feldspar in the anorthositic host rock, ${ }^{6}$ possibly induced by the intrusion of Pilanesbergage dykes. Scattered grains of chromite are present in the anorthosite and these can also found in the prehnite and hydrogrossular zones. Many of the chromite grains are encapsulated by a thin halo of green hibschite. At Buffelsfontein, a thick zone of hibschite is present and consists of layers of deep pink and green garnet with a network of chromite seams.

The Rustenburg material has been known for many years and has been collected and fashioned by local lapidarists. Another deposit that has only received scant attention occurs in the Steelpoort district of the Limpopo
Province. This site was discovered in 1907 on the farm Hendriksdal 216 JT, "17 kilometres [8 miles] west of Fort Burger".3 (p. 50) Here, the hibschite occurs in thin veins, several centimetres thick, is pale green and also closely associated with chromitite layers.

\section{References:}

1. Mindat.org: https://www.mindat.org/min-8637. html, accessed November 2020.

2. Page, D.C. (1970). The mineralogy of South African jade and the associated rocks in the district of Rustenburg, western Transvaal. M.Sc. thesis (unpublished), University of Pretoria, Pretoria, South Africa, $74 \mathrm{pp}$.

3. Hall, A.L. (1924). On "jade" (massive garnet) from the Bushveld in the western Transvaal. Transactions of the Geological Society of South Africa, 27, 39-55.

4. Frankel, J.J. (1959). Uvarovite garnet and South African jade (hydrogrossular) from the Bushveld Complex, South Africa. American Mineralogist, 41, 565-591.

5. Gemdat.org: https://www.gemdat.org/gem-1974. html, accessed November 2020.

6. Tilley, C.E. (1957). On the replacement of anorthosite by hydrogrossular in the Transvaal. Transactions of the Geological Society of South Africa, 60, 15-20.

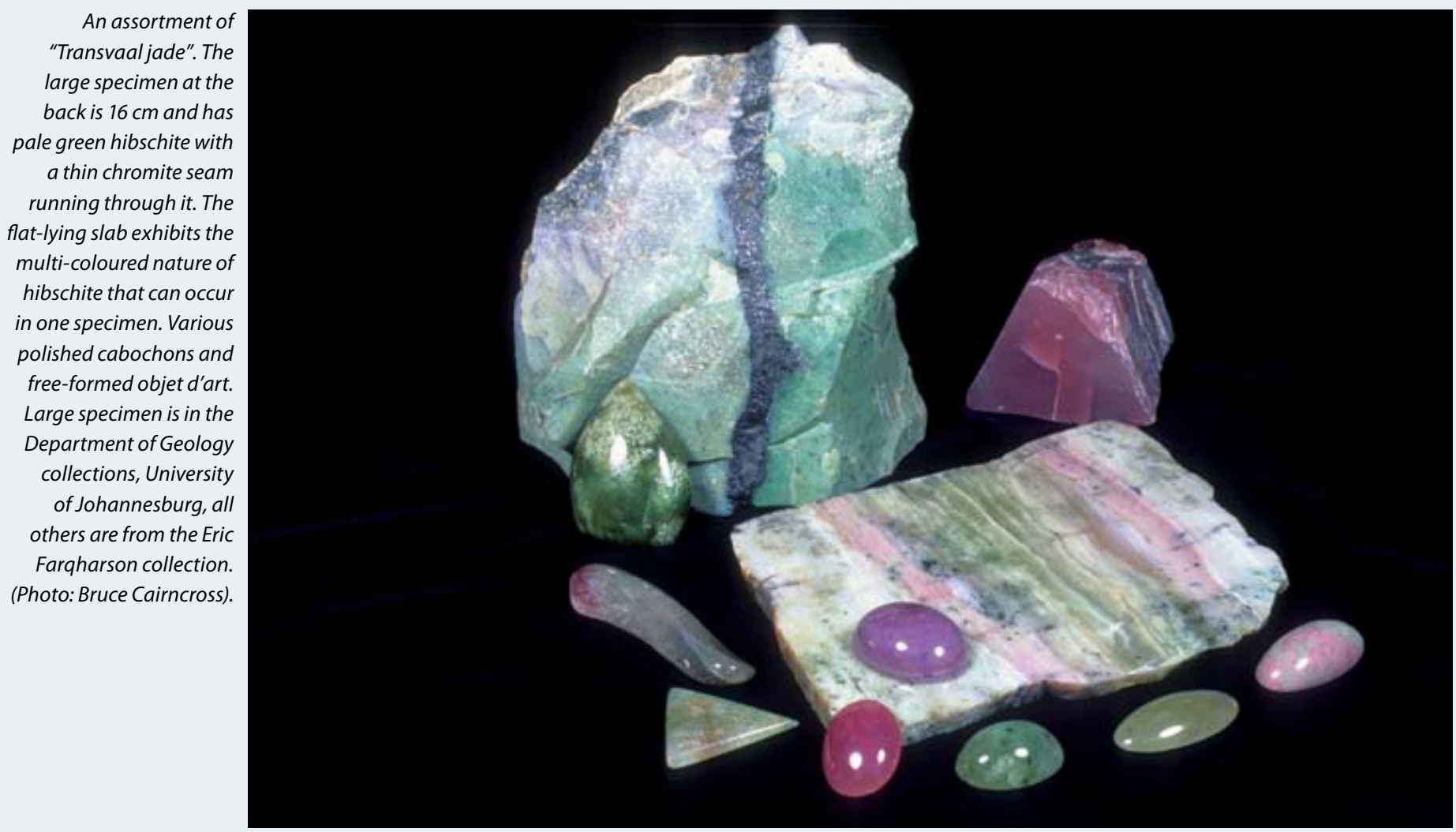




\section{obituary}

\section{Christian Roering}

15 January 1935 to 30 October 2020

Christian Roering was born in Vryheid, Natal, on January 15 1935, to a Norwegian father and a Swedish mother. He attended secondary school in Benoni West and matriculated from King Edward VII High School in Johannesburg in 1951. At that time he was completely undecided about a career, but his father insisted that the only good jobs with sound security were to be found in the gold mining profession of South Africa. Towards that aim, Chris completed a BSC (Eng) degree at the University of the Witwatersrand (Wits) in 1954 and in 1955 he left South Africa for the land of his ancestors, Sweden, where he obtained an MSc (Eng) degree in 1960 also from Wits, working on the sulphide ore deposits of the Rävlidenfältet Västerbotten in northern Sweden. He was one of the first students to use an electron microprobe, which he applied to the study of sphalerite. During his stay in Sweden, Chris was particularly influenced by Professors S. Gavelin, S. Landegren, F.E. Wickman, O. Odman and T. Barth.

Chris returned to South Africa in 1959 to be appointed by Prof. T.W. Gevers (Head of the Department of Geology at Wits University) as the first full-time staff member of the Economic Geology Research Unit (EGRU) that was established in October 1957 by the Chamber of Mines of South Africa. Chris held the position of Research Fellow until his resignation in February 1968. Prior to his return to South Africa and in preparation for his research position at EGRU, Professor Gevers sent Chris to a formal course at the International Training Centre for Photogeology in Delft, Holland. During this time Chris also visited the Photogeological Section of the Overseas Geological Survey of the Leeds University Research Institute of African Geology, and the Imperial College of Science in England where he met a young structural geologist

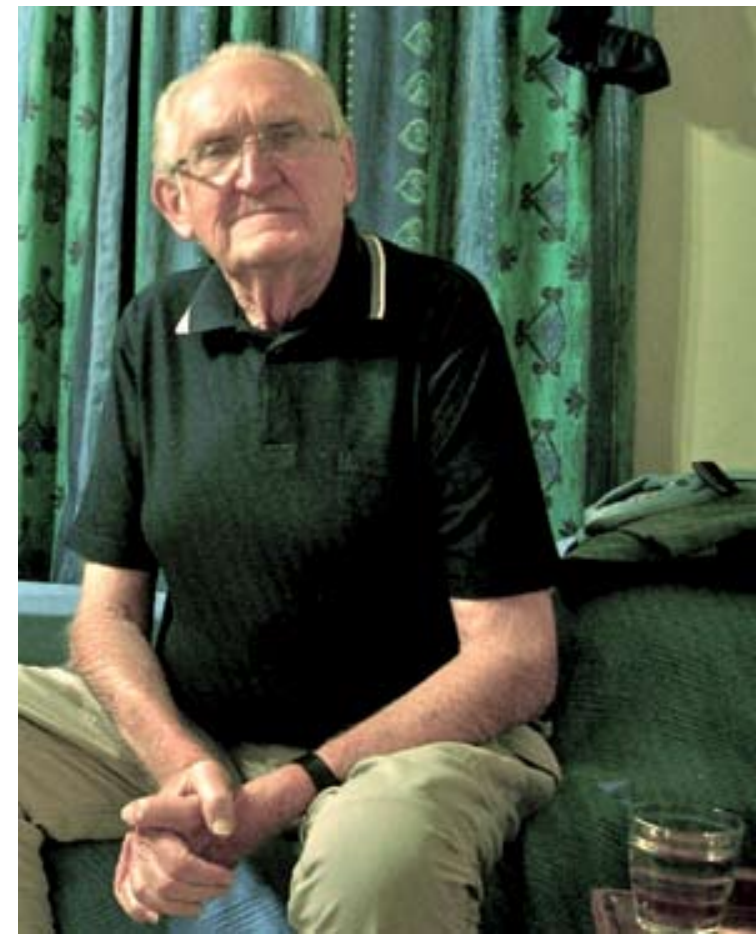

named Dr J.G. Ramsey, whose ideas on structural geology greatly excited him.

For his first assignment at EGRU, Prof. Gevers sent Chris to map the lithium-bearing pegmatites of the Karibib District of what was then South West Africa. This formed the basis for his PhD dissertation at Wits in 1963, with professors R. Jahns and E. Cameron as his external examiners.

By the time that Prof. Des Pretorius became the head of EGRU, the Unit had become more attuned to the needs of the South African mining industry to determine the nature and distribution of gold mineralisation in South Africa. Chris accordingly turned his attention to the Barberton Goldfield, where he initially undertook structural mapping of the Saddleback Syncline south of the main gold-producing region. Chris was an excellent all-round geological enthusiast, but his main interests centred around structural geology and as such he 
motivated a visit to Wits University by Prof. John Ramsay, one of the leading structural geologists in the world at the time. Chris accompanied John Ramsay and a class of 4th year students to the Barberton Greenstone Belt, where Prof Ramsay was able to demonstrate his structural mapping techniques to the students. This led to three students (Carl Anhaeusser, Morris Viljoen and Chris Van Vuuren) taking up mapping projects supervised by Chris Roering that were offered by EGRU to the Honours Class of 1961. This laid the groundwork for the Upper Mantle Project that was conceived during a discussion among Louis Nicolaysen, Des Pretorius, and Chris Roering, and Chris was delegated to approach Morris and Richard Viljoen and try to convince them to leave the Johannesburg Consolidated Investment Company (JCl) and become involved in the project. This they did and the lasting impact of this project is that it promoted the Barberton Greenstone Belt internationally as a classical Archaean terrane holding clues to the earliest beginnings of greenstone belt evolution and crustal development. Geological investigations linked to gold exploration and controls of mineralisation underpinned the enthusiasm and support afforded by the Barberton mining industry to the type of research that was carried out over the years by EGRU and which was initiated by Chris and his students in the early 1960s. Chris Roering was not only responsible for initiating the careers of the students he supervised but also for pioneering in

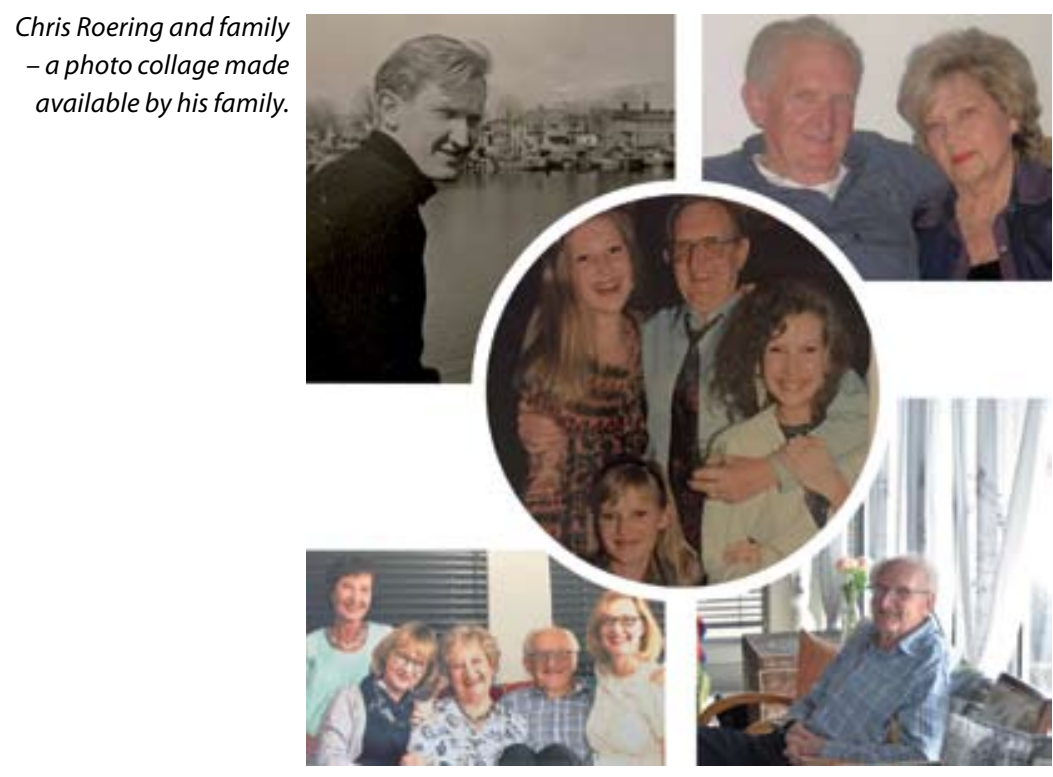

South Africa the use of stereographic projections of structural data for the understanding of structures and the concept that small-scale structures reflect largescale structures.

In mid-1966, Chris started mapping along the northern margin of the Witwatersrand Basin. However, by 1968 he had become bored with both the Upper Mantle Project and mapping in the Witwatersrand. He felt he needed to find out how geology was applied to exploration by the mining companies and so he joined General Mining and Finance Corporation as Chief Geologist in Windhoek. Later in 1970 he was appointed to the post of Consulting Geologist in charge of base metals and was stationed in Johannesburg. By 1971, however, Chris realised that his real interests were mainly academic and could not be satisfied in industry, where his future lay with management. When Wilhelm Verwoerd left Rand Afrikaans University (RAU) to become Professor at Stellenbosch, Chris took up the post of Senior Lecturer in the Department of Geology. Willem van Biljon, Nic Beukes, Dirk van Reenen, and Chris became the nucleus of the new Department, which had only started operations three years previously.

One of the most challenging aspects of Chris's work at RAU occurred after about five years, when he actually had to hold down two jobs at once. He had his normal job at the University and was also seconded to the Chamber of Mines Research Organisation (COMRO), from 1976 to 1982, to undertake research in rock mechanics. Chris felt that this experience was vital to him as a structural geologist because, in an environment dominated by engineers, he obtained a very much deeper physical and mechanical understanding of rock deformation. At COMRO he worked with Neville Cook, Miklosh Salamon, Nick Gay, and Noel Joughin. Seismic and brittle fracture research on deep gold mines in South Africa is unparalleled and COMRO was a 'school' that had no counterpart anywhere in the world! Chris also had the privilege of obtaining first-hand experience of a rock-burst and associated rockfall in which he was injured on the Western Deep Levels Gold Mine. 
Chris was promoted to a full Professorship at RAU in 1980. A year later he stumbled across highly deformed conglomerates in the Ventersdorp strata near Swartkops that so intrigued him that in 1982 he stopped working at COMRO and became seconded to EGRU in order to remap the Swartkops area of the Witwatersrand. From this work came the recognition of some of the most spectacular examples of thrust faulting in the Witwatersrand succession and the rediscovery of the fact that thrust tectonics played a major role in the evolution of the Witwatersrand goldfield. His study of the structural geology of the Swartkops outlier north of Krugersdorp led to a publication that was awarded the Jubilee Medal of the Geological Society. Professor Anhaeusser, who in 1985 was President of the Geological Society, had the honour of presenting Chris, his former mentor, with the medal at Kelvin House, Johannesburg.

In 1984, Chris became Head of the Geology Department at Rand Afrikaans University, which was renamed University of Johannesburg (UJ) in 2004, and with him came a drive for increasing the research output of the Department. He wanted the Department to enjoy a much higher national and international reputation, and to do so he set out to create a core of highly devoted scientists. The Department expanded to eight academic staff, now also including Bruce Cairncross, Jay Barton and

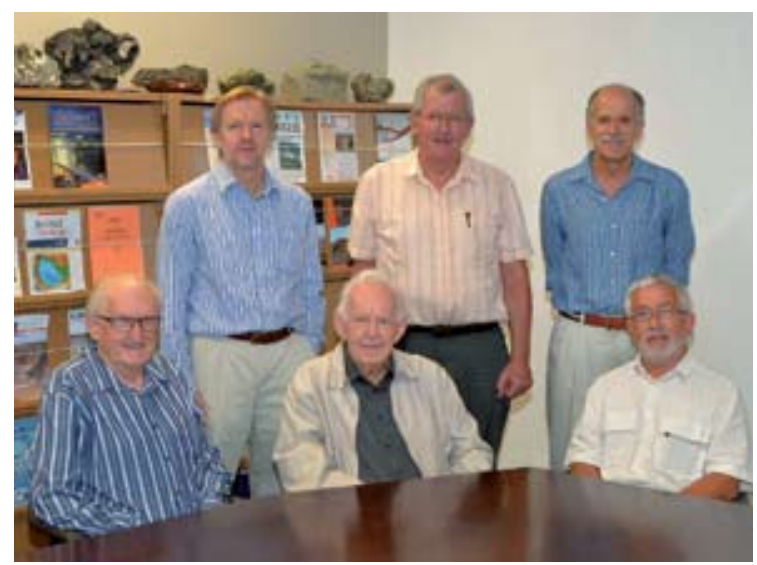

Heads of the Department of Geology at RAU/UJ from its inception in 1967 to 2012, when the photo was taken.

Back row L-R: Bruce Cairncross (2003-2015), Dirk van Reenen (1995-1997), Harry Brown (Co-Head: 2005-2006; Deputy Head: 2007-2019).

Front row L-R: Chris Roering (1984-1994), Willem van Biljon (1967-1983), Nic Beukes (1998-2002).

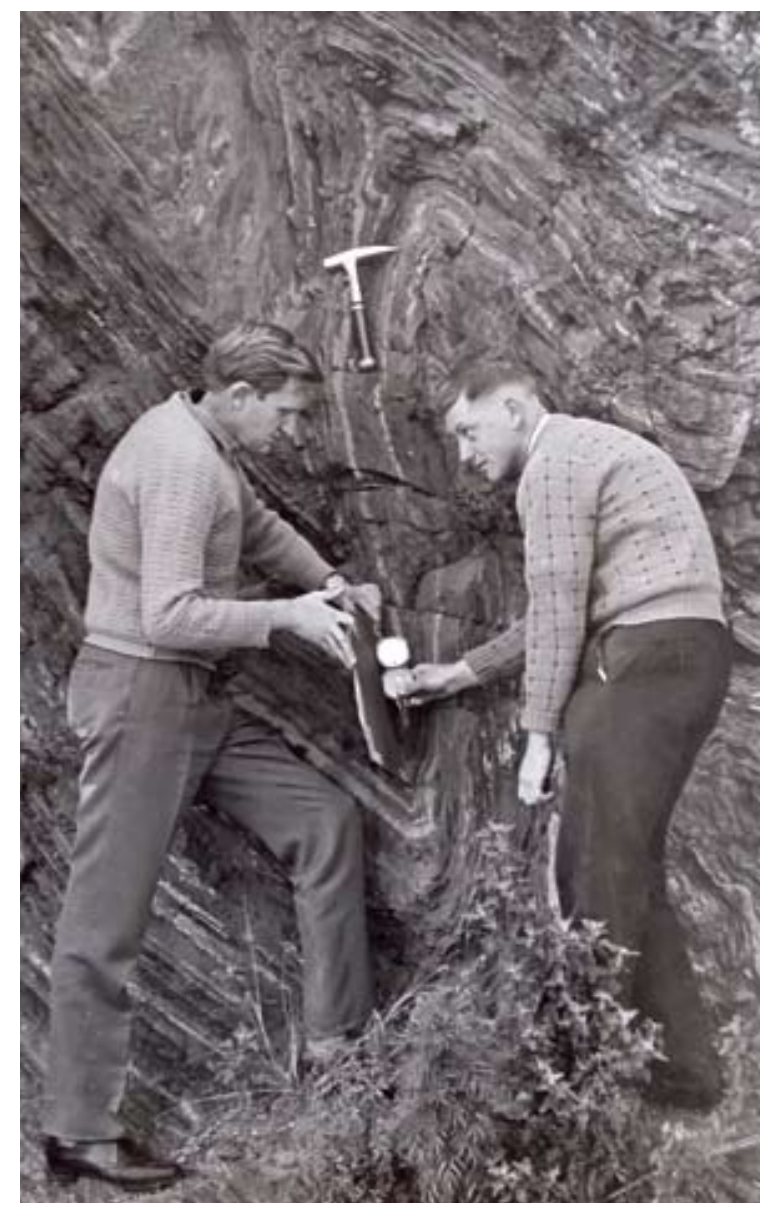

Chris Roering (left) with MSc student Carl Anhaeusser measuring the fold axis of structures in the Contorted Bed of the Parktown Formation (Hospital Hill Subgroup, Witwatersrand Supergroup) in a road cutting in Jan Smuts Avenue opposite the University of the Witwatersrand.

Lew Ashwal, who Chris largely shielded from the politics of the University and other governmental agencies, to enable them to get on with research.

One of Chris's many achievements was getting approval from the university management to build the world's largest experimental flume tank at RAU, where today the Kentucky Fried Chicken franchise stands on Campus Square Shopping Centre. Through his contacts at the Chamber of Mines, Chris heard of some huge water pumps that were being decommissioned from the mines. So, he approached the sedimentologists in the Geology Department, Nic Beukes and Bruce Cairncross, and from those early discussions the flume was built. It was on such a scale that the hydrodynamic behaviour of gravel-sized sediment could be modelled, something that had never been done before. This project ran for a few years and several important reports were produced modelling the behaviour of heavy minerals and gravels and comparing these to gold distribution in the Witwatersrand conglomerates. It was only when the 
university management decided to reallocate the land where the flume was built to house the current shopping complex that the flume had to be decommissioned and disassembled.

By the early 1980 s, Chris had also developed a long-lasting interest in the complex tectonics of the Neoarchaean LimpopoComplexthatcontinued long afterhis retirement as head of the Department of Geology at RAU at the end of December 1994, where he had worked for 23 years. Chris attended numerous field trips to this high-grade gneiss terrane, contributed to International Limpopo Field Workshops in 1982, 1990 and 1995, and co-authored different papers with Dirk van Reenen and Andre Smit dealing with aspects of the geotectonic evolution of the Limpopo Complex. Chris also acted as study advisor for Dirk van Reenen's PhD. Chris Roering was simply the best and most knowledgeable sounding board against which Dirk van Reenen and Andre Smit could continuously test new ideas based on new field, structural, and petrological data obtained from the Limpopo Complex. Dirk received a phone call from Chris a few weeks before his death on 30 October, during which he shared new insight into the evolution of the Limpopo Complex that occurred to him while relaxing in the bath. Tragically there was no time to follow up on Chris's new insight.

During his time at the then RAU, Chris Roering proved to be a mentor to both his own and other students and the academic staff of the Department. Hardly anyone spent time in the Department during those years without being influenced by Chris's positive personality, unique sense of humour, and highly effective way of taking care of administration, driven by the fact that he had little time for red tape and did not enjoy having staff meetings. In the past very few formal meetings were held to deal with administrative issues and most departmental matters were discussed and resolved around the tea-table.

Staff and students from Wits and RAU owe Chris Roering's memory a tremendous vote of thanks for the positive way in which he influenced our personal lives and academic careers. Chris was especially influential in guiding my academic career at RAU and then at $\mathrm{UJ}$ both as mentor and long-time friend and continued to do so after his retirement at the end of 1994.

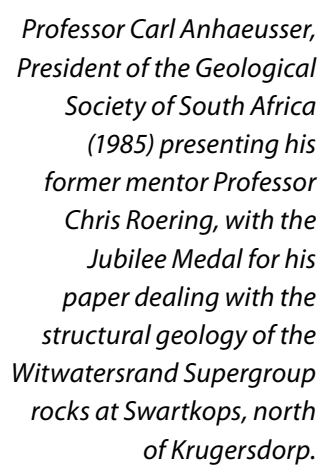

Professor Carl Anhaeusser, President of the Geological Society of South Africa (1985) presenting his former mentor Professor Chris Roering, with the Jubilee Medal for his paper dealing with the structural geology of the Witwatersrand Supergroup rocks at Swartkops, north of Krugersdorp.

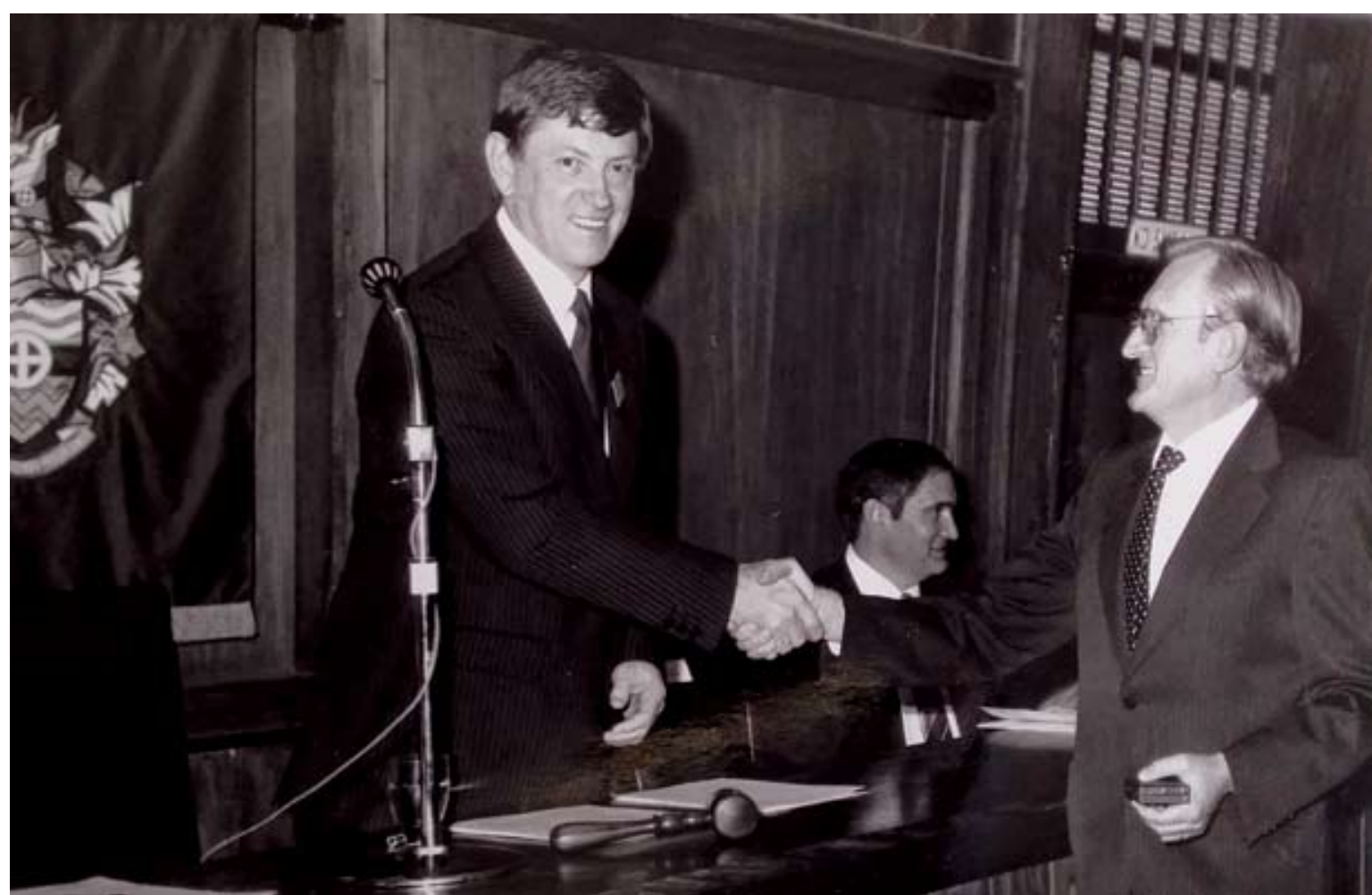


Chris married Elizabeth Maria (Elma) Petronella Heyneke on 10 October 1963. Elma graduated from the University of Pretoria as a high school teacher but in her late fifties discovered a hidden talent in watercolour painting. The couple had three daughters, of which the eldest, Marina, obtained a national diploma in Interior Designing, while Amanda qualified with a degree in commerce. The youngest, Elma, qualified as a medical doctor and then as a radiologist. During his career, Chris was always supported and encouraged by Elma and his three daughters.

Chris's most significant publications, which reflect his wide interests and experience, are in chronological order below:

1. Roering, C. \& Bizouard, H. (1958). An investigation of sphalerite. Geo/. F Forhandl., Stockholm, 80, 309314.

2. Roering, C. \& Gevers, T.W. (1964). Lithium- and beryllium- bearing pegmatites in the Karibib District, South West Africa. In: Haughton, S.H. (Ed.), The Geology of Some Ore Deposits in South Africa, II. Geol. Soc. S. Afr., 463-495.

3. Roering, C. (1966). Aspects of the genesis and crystallization sequence of the Karibib pegmatites, South West Africa. Econ. Geol., 61, 83-89.

4. Roering, C. (1968). The geometrical significance of natural en-echelon crack arrays. Tectonophysics, 5, 107-123.

5. Anhaeusser, C.R., Roering, C., Viljoen, M.J. \& Viljoen, R.P. (1968). The Barberton Mountain Land: A model of the elements and evolution of an Archean fold belt. Annex. Trans. Geol. Soc. S. Afr., 71, 225-254.

6. Roering, C. (1978). Tectonic overpressure as revealed by simple rheological modelling. Trans. Geol. Soc. S. Afr., 81, 165-171.

7. Potgieter, C.J. \& Roering, C. (1984). The influence of geology on the mechanisms of mining associated seismology in the Klerksdorp goldfield. In: Gay, N.C. \& Wainright, E.J. (Eds.), Rockbursts and Seismicity in Mines. S. Afr. Inst. Min. Met., 45-50.

8. Rorke, A.J. \& Roering, C. (1984). Source mechanism studies of mining induced seismic events in a deep- level gold mine. In: Gay, N. C. \& Wainright, E. J. (Eds.), Rockbursts and Seismicity in Mines. S. Afr. Inst. Min. Met., 51-56.

9. Roering, C. (1984). The Witwatersrand Supergroup at Swartkops: A re- examination of the structural geology. Trans. Geol. Soc. S. Afr., 87, 87-99.

10. Van Reenen, D.D., Barton, J.M., Jr., Roering, C., Smit, C.A. \& Van Schalkwyk, J.P. (1987). Deep crustal response to continental collision: The Limpopo Belt of southern Africa. Geology, 15, 11-14.

11. Roering, C. \& Smit, C.A. (1987). Bedding parallel shear, thrusting and quartz vein formation in Witwatersrand quartrzites. J. Struct. Geol., 9, 419427.

12. Van Reenen, D.D., Roering, C., Smit, C.A., Van Schalkwyk, J.P. \& Barton, J.M., Jr. (1988). Evolution of the northern high-grade margin of the Kaapvaal craton. J. Geol., 96, 549-560.

13. Van der Merwe, R., Roering, C. \& Smit, C.A. (1988). Slickenside analysis of the Potchefstroom fault. $S$. Afr. J. Geol., 91, 264-274.

14. Cheney, E.S., Roering, C. \& Winter, H. de la R. (1990). The Archean-Proterozoic boundary in the Kaapvaal Province of southern Africa. Precambrian Res., 46, 329-340.

15. Roering, C., Barton, J.M., Jr. \& Winter, H. de la R. (1990). The Vredefort structure: a perspective with regard to new tectonic data from adjoining terranes. Tectonophysics, 171, 7-22.

16. Berlenbach, J.W. \& Roering, C. (1992). Sheath-like structures in pseudotachylytes. J. Struct. Geol., 14, 847-856.

17. De Wit, M.J., Roering, C., Armstrong, R.A., Hart, R.J., Tredoux, M., De Ronde, C.E.J., Pberdy, E., Green, R.W.E., Hart, R.A. (1992). Formation of an Archaean continent. Nature, 357, 553-562.

18. Roering, C., Van Reenen, D.D., Smit, C.A., Barton, J.M. Jr., De Beer, J.H., De Wit, M.J., Stettler, E.H., Van Schalkwyk, J.F., Stevens, G., \& Pretorius, S. (1992a). Tectonic model for the evolution of the Limpopo Belt. In: D.D. Van Reenen, C. Roering, L.D. Ashwal and M.J. de Wit (Editors). The Archaean Limpopo Granulite Belt:Tectonics and Deep Crustal Processes. Precambrian Res., 55, 539-552. 
19. Roering, C, Van Reenen, D.D., De Wit, M.J., Smit, C.A., De Beer, J.H., \& Van Schalkwyk, J.F. (1992b). Structural geological and metamorphic significance of the Kaapvaal Craton-Limpopo Belt contact. In: D.D. Van Reenen, C. Roering, L.D. Ashwal and M.J. de Wit (Editors). The Archaean Limpopo Granulite Belt: Tectonics and Deep Crustal Processes. Precambrian Res., 55, 69-80.

20. Smit, C.A., Roering, C., \& Van Reenen, D.D. (1992c). The structural framework of the southern margin of the Limpopo Belt, South Africa. In: D.D. Van Reenen, C. Roering, L.D. Ashwal and M.J. de Wit (Editors). The Archaean Limpopo Granulite Belt: Tectonics and Deep Crustal Processes. Precambrian Res., 55, 51-67.

21. Van Reenen, D.D., Roering, C., Ashwal, L.D. and De Wit, M.J. 1992. Regional Geological Setting of the Limpopo Belt. Precambrian Res., 55, 1-6.

22. Van Schalkwyk, J.F., De Wit, M.J., Roering, C and Van Reenen, D.D. (1993). Tectono-metamorphic evolution of the simatic basement of the Pietersburg Greenstone Belt relative to the Limpopo Orogeny. Evidence from serpentinite. Precambrian Res., 61, 67-88.

23. Van Reenen, D.D., Pretorius, A.I., and Roering, C. (1994). Characterization of fluids associated with gold mineralization and with regional high-temperature retrogression of granulites in the Limpopo Belt, South Africa. Geochimica et Cosmochimica Acta, 58/3, 1147-1159.

24. Barton, J.M. Jr. (1995). Professor Christian Roering. S. Afr. J. Geol., 98(4), 332-334.

25. Coetzee, D.S., Van Reenen, D.D. \& Roering, C. (1995). Quartz vein formation, metasomatism and fluid inclusions associated with thrusting and beddingparallel shear in Witwatersrand quartzites, South Africa. S. Afr. J. Geol., 98/4.

26. Roering, C., Van Reenen, D.D., Smit, C.A. \& Du Tait, R. (1995). Deep crustal embrittlement and fluid flow in granulites. S. Afr. J. Geol., 103, 673-686.

27. Kramers, J.D., McCourt, S., Roering, C., Smit, C.A., and van Reenen, D.D. (2011). Tectonic models proposed for the Limpopo Complex, mutual compatibilities and constraints. In: Geological Society of America
Memoir 207 "Origin and evolution of Precambrian high-grade gneiss terrains, with special emphasis on the Limpopo Complex of southern Africa" (Edited by D.D. van Reenen, J. Kramers, S. McCourt and L.L. Perchuk), pp. 311-314.

28. Smit, C.A., Van Reenen, D.D., Roering, C., Boshoff, R. and Perchuk, L.L. (2011). The Neoarchean to Paleoproterozoic evolution of the polymetamorphic Central Zone of the Limpopo Complex. In: Geological Society of America Memoir 207 "Origin and evolution of Precambrian high-grade gneiss terrains, with special emphasis on the Limpopo Complex of southern Africa" (Edited by D.D. van Reenen, J. Kramers, S. McCourt and L.L. Perchuk), pp. 213-244.

29. Van Reenen, D.D., Smit, C.A., Perchuk, L.L., Roering, C. and Boshoff, R. (2011). Thrust exhumation of the Neoarchean UHT Southern Marginal Zone, Limpopo Complex: convergence of decompression-cooling paths in the hanging wall and prograde P-T paths in the footwall. In: Geological Society of America Memoir 207 "Origin and evolution of Precambrian high-grade gneiss terrains, with special emphasis on the Limpopo Complex of southern Africa" (Edited by D.D. van Reenen, J. Kramers, S. McCourt and L.L. Perchuk), pp. 189-212.

30. Smit, C.A., Van Reenen, D.D., Roering, C. (2014). Role of fluids in the exhumation of the Southern Marginal Zone of the Limpopo Complex, South Africa. Precambrian Res., 253, 81-95.

31. Van Reenen, D.D., Huizenga, J.M., Smit, C.A., Roering, C. (2014). Fluid-rock interaction during high-grade metamorphism: Instructive examples from the Southern Marginal Zone of the Limpopo Complex, South Africa. Precambrian Res., 253, 63-80

By Dirk van Reenen with contributions from Prof. Carl Anhaeusser and Prof Bruce Cairncross. The dedication that Prof Jay Barton prepared in collaboration with Prof Roering at the time of his retirement from the Rand Afrikaans University at the end of 1994 (Barton, 1995) is acknowledged as an important source of information. 


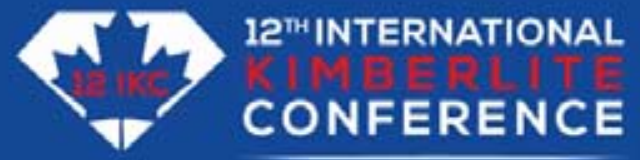

30 YEARS OF DIAMONDS IN CANADA

15-19 August 2022 - Yellowknife

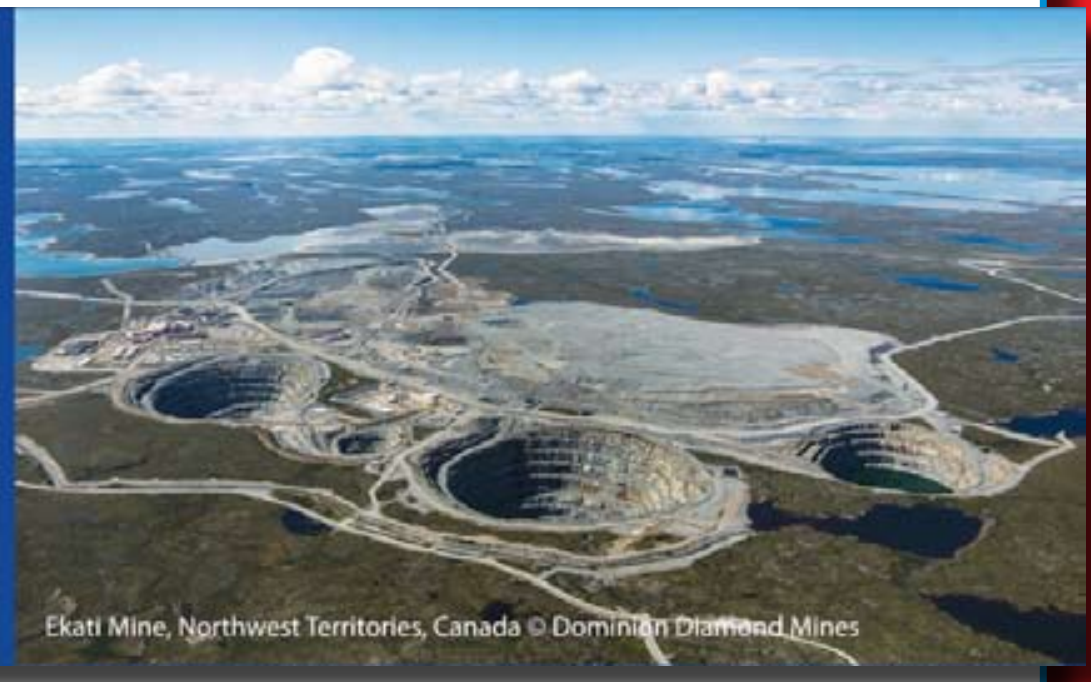

\section{IKC POSTPONED TO 2022}

The 12th International Kimberlite Conference is postponed to

$$
15 \text { - } 19 \text { August } 2022
$$

The postponement reflects the COVID-19 situation and resulting difficult times for the diamond industry together with the goal of maintaining the symbiotic mix of industry and academia that makes International Kimberlite Conferences unique. This change has the full support of the International Kimberlite Conference Advisory Committee

The intention is to host the 12IKC at the same venues in Yellowknife, with the same scientific programme, field trips, short courses and social events, but delayed by one year.

Further updates will be available on the 12 IKC Bulletin Board as well as via the 12 IKC mailing list.

We look forward to welcoming you to Yellowknife in 2022! 


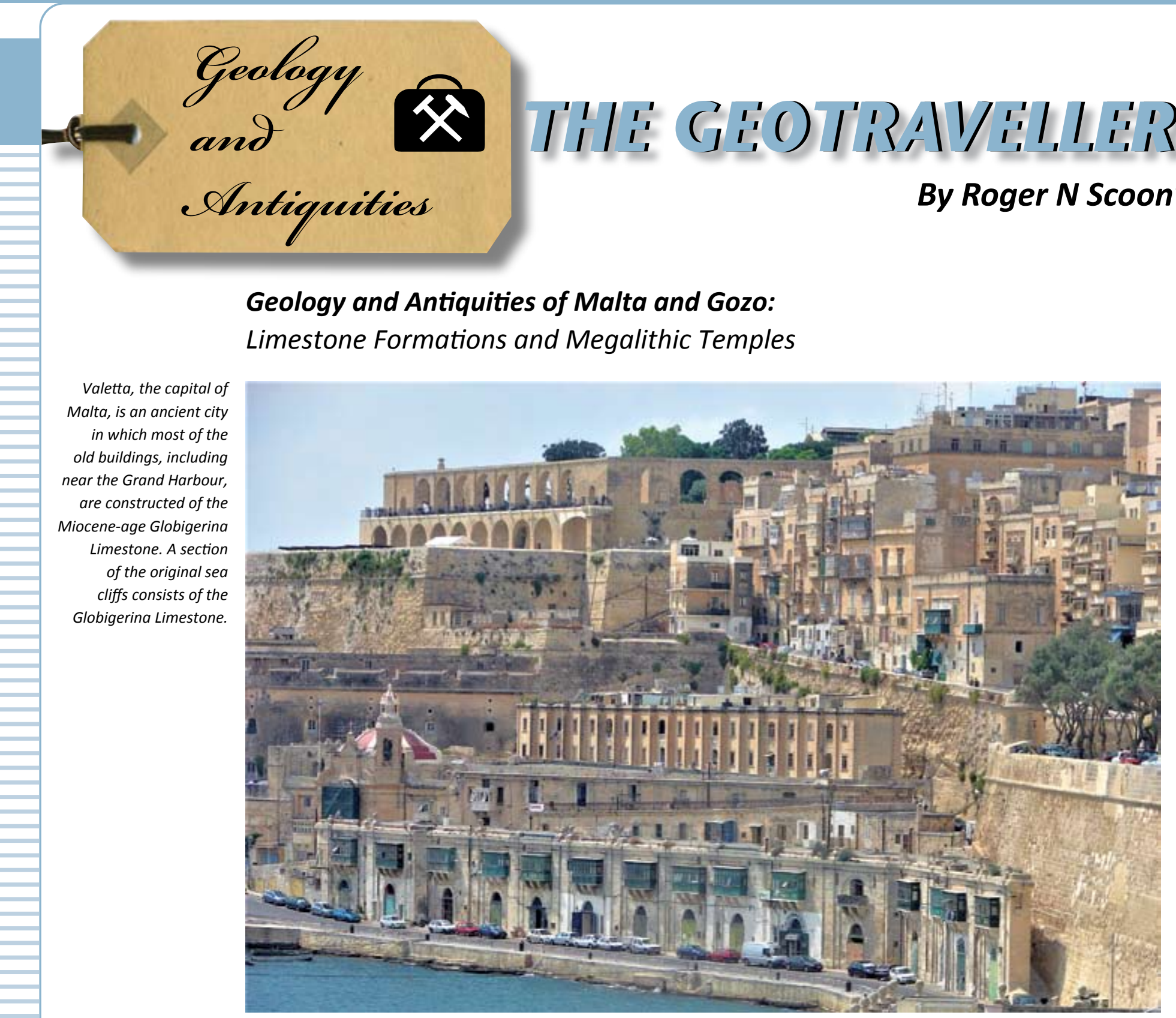

Malta and Gozo are the dominant islands of an archipelago situated in the Straits of Sicily, a mostly submerged continental platform in the central Mediterranean. The Straits of Sicily separates deep basins associated with the Tyrrhenian Sea (northwest) and the lonian Sea (east). The Maltese archipelago attracts large numbers of tourists to scenic beaches, coastal landforms, and historical features that include castles and palaces. The capital city of Valletta has strong links with the Medieval period, including the Knight Templar. Valetta is built around the Grand Harbour, one of the largest and safest anchorages in the Mediterranean. The Siege of Malta is one of the most memorable events of the Second World War and the Ta'Qali National Park, near Rabat, incorporates a disused airfield. Archaeological sites include megalithic temples, "unique architectural masterpieces", constructed from giant standing or worshipping stones. The megalithic temples define the Ggantija historical phase (3600-3000 $B C)$ and have been awarded World Heritage status.

The geological setting of the Maltese archipelago is dominated by sedimentary rocks deposited on a continental platform located between Sicily and Tunisia. ${ }^{1,2}$ The principal component is extensive limestone formations, which have a Late Oligocene and Miocene age. Of particular interest is the Miocene-age Globigerina Limestone, a thick succession of honey-yellow or pale brown limestone that has been extensively quarried. The "Maltese Globigerina Limestone" is designated by the IUGS as a "Global Heritage Stone Resource".

The Maltese archipelago occurs in a relatively stable region of the Mediterranean, some distance from active subduction zones associated with ongoing collision of the 
African and Eurasian Plates. The Mediterranean comprises multiple interlocking basins, many of which remain tectonically active with subduction zones that include relicts of the ancient Tethys Ocean. ${ }^{3,4}$ The complexity of the collision has resulted in the formation of several microplates, e.g., the Adriatic Microplate. The collision in the central Mediterranean is demarcated by the ApennineMaghreb Thrust, a complex, curvilinear feature where the northward-pushing African Plate and the westwardmigrating Adriatic Microplate are being subducted beneath the Eurasian Plate. ${ }^{5}$ The Apennine-Maghreb Thrust is primarily a Pliocene-Quaternary feature and is envisaged as a rejuvenation of the long drawn out Alpine Orogeny.

The accretionary nature of the convergent boundary in the central Mediterranean has resulted in the formation of a back-arc basin associated with the Tyrrhenian Sea and a fore-arc basin designated as the Calabrian Wedge. The subduction is driving active volcanism in the Campanian Volcanic Field (Bay of Naples) and in the Aeolian Volcanic Arc. ${ }^{6}$ The Etna Volcano is an isolated feature related to a complex boundary zone between Sicily and the Calabrian Wedge. The absence of volcanism from the Maltese archipelago is a notable feature, although the island of

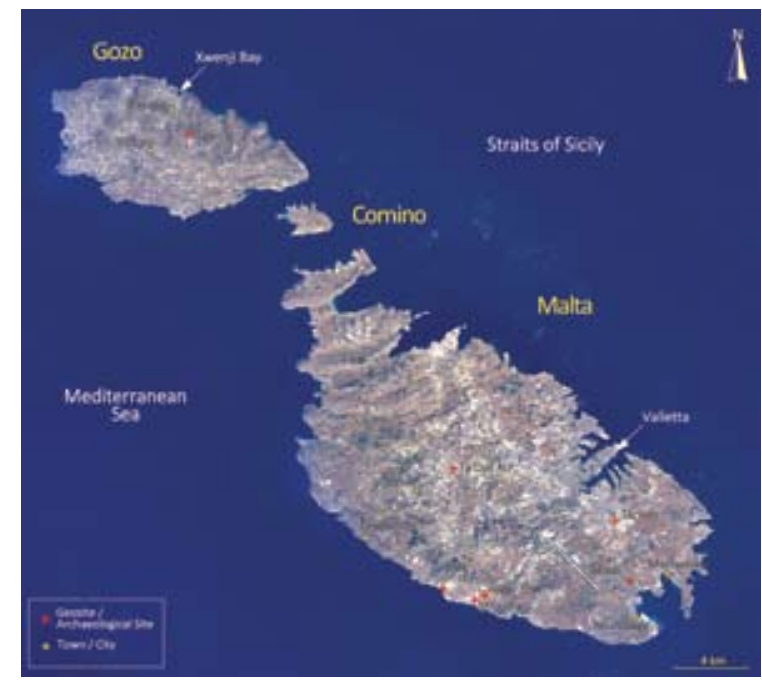

Image of the Maltese archipelago showing the three main islands and localities referred to in the text (source: Google Earth).

Pantelleria, which is situated in a transform fault that cuts the Apennine-Maghreb Thrust, is the exposed part of an active volcano located within a giant, mostly subterranean caldera complex. ${ }^{7}$

The Straits of Sicily is part of a broad rift between the Tyrrhenian and lonian Basins in which three grabens are recognised: the Pantelleria graben, the Malta graben and the Linosa graben. The platform between the Maltese

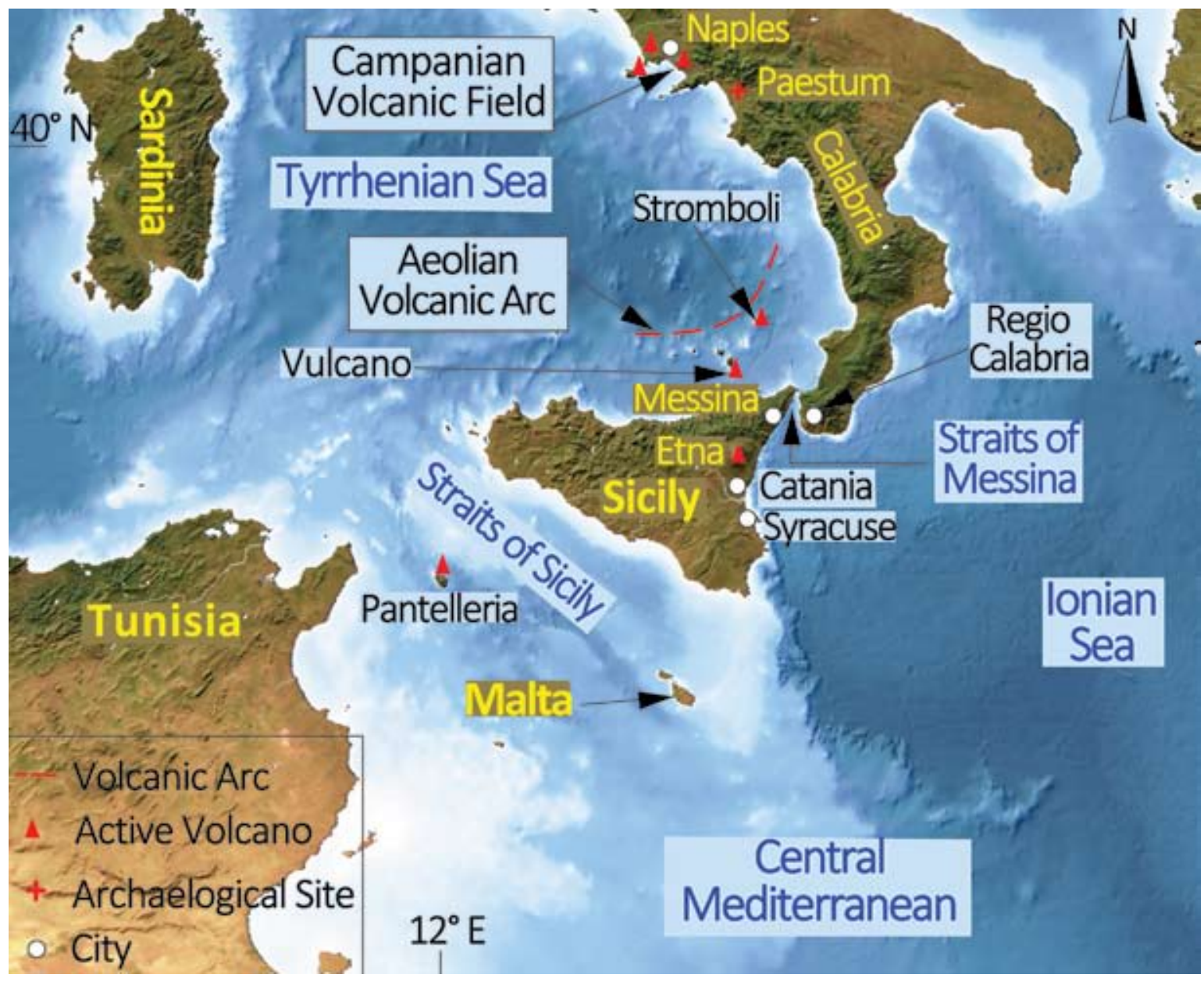

The Maltese

archipelago is situated in the Straits of Sicily, a shallow region of the Mediterranean surrounded by deep basins

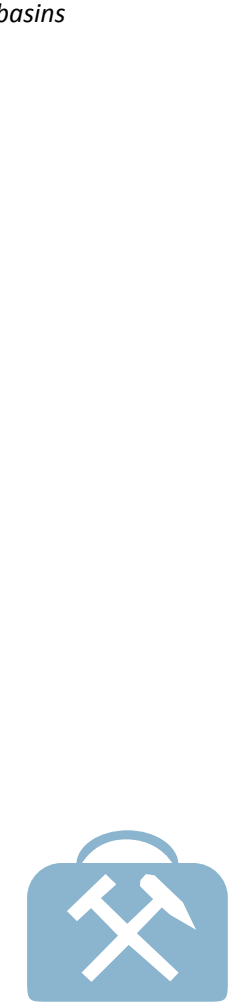




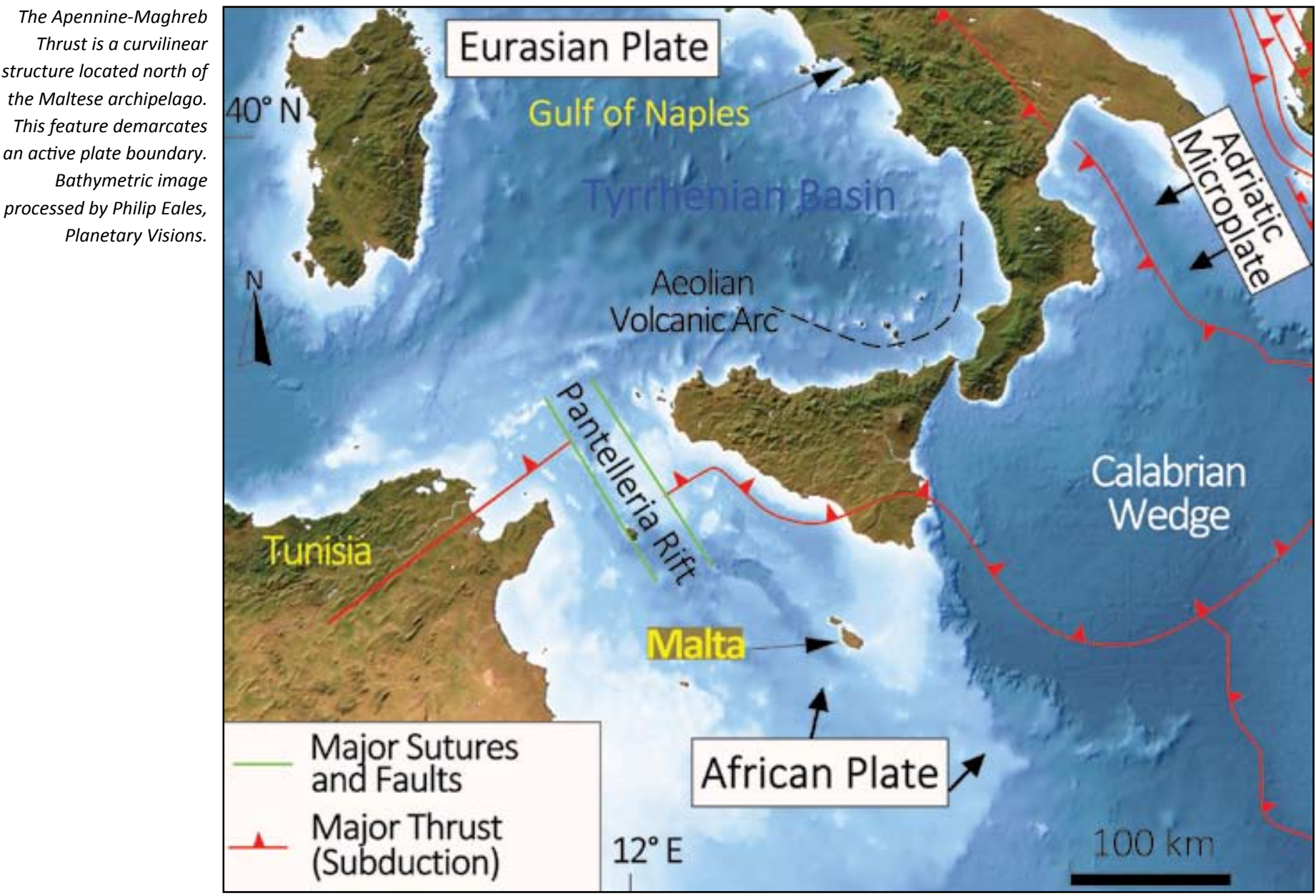

archipelago and Sicily has an average depth of less than $100 \mathrm{~m}$. The boundary with the adjacent deep-water basins is demarcated on a bathymetric map. The Tyrrhenian Sea has a maximum depth of $3785 \mathrm{~m}$. The Ionian Sea includes the Calypso Trench (5267 m).

Crustal extension associated with the Tyrrhenian Sea and the Calabria Wedge has resulted in catastrophic earthquakes in southern Italy and eastern Sicily. ${ }^{8,9}$ Seismicity is ascribed to release of stress from the Eurasian Plate affected by the Apennine-Maghreb Thrust. Many of the shallow and most hazardous earthquakes are related to faults associated with the Siculo-Calabrian Rift, an area of crustal extension located between the eastern coast of Sicily and the western coast of Calabria. The fault zone includes the Straits of Messina. The Sicilian earthquake of $1693 A D$ (which measured 7.4 on the Richter Scale) affected a total area of $5600 \mathrm{~km}^{2}$. This event had catastrophic consequences for the cities of Catania and Messina and extended as far as Malta. The 1169 AD event was probably of a similar intensity but is less well known. Many fatalities during these events were associated with tsunamis that struck the lonian coasts of Sicily and Calabria (southern Italy).
A geological section extending from Dingli Cliffs (southwest) to Valetta (northeast) shows the stratigraphy of Malta, which has been described in detail by Pedley et al. ${ }^{1,2}$ The Dingli Cliffs are the highest point in Malta (elevation of $280 \mathrm{~m}$ ) and are a popular viewpoint. The basal part of the cliff consists of resistant limestone (Upper Oligocene). Valetta occurs in a relatively low-lying basin dominated by softer limestones and clays (Miocene). Uplift on the flanks of the Malta graben commenced in the Late Miocene. The uplifted section of the continental platform associated with the archipelago is tilted northeast. Faulting during the Pliocene resulted in two sets of extensional faults. The primary structures trend NW-SE, parallel to the alignment of the archipelago. Subsidiary faults trend WSW-ENE. Some of the Pliocene faults remain active and can trigger modest seismic events. The regional tilt has had the effect of creating a distinct physiography in the island of Malta. High, near-vertical cliffs occur on the southern coastline; the interior reveals gentle northeast-facing slopes; and the low-lying northern coastline is indented by graben faults, e.g., the Grand Harbour.

The Upper Oligocene strata are represented by the Lower Coralline Limestone Formation. The estimated 


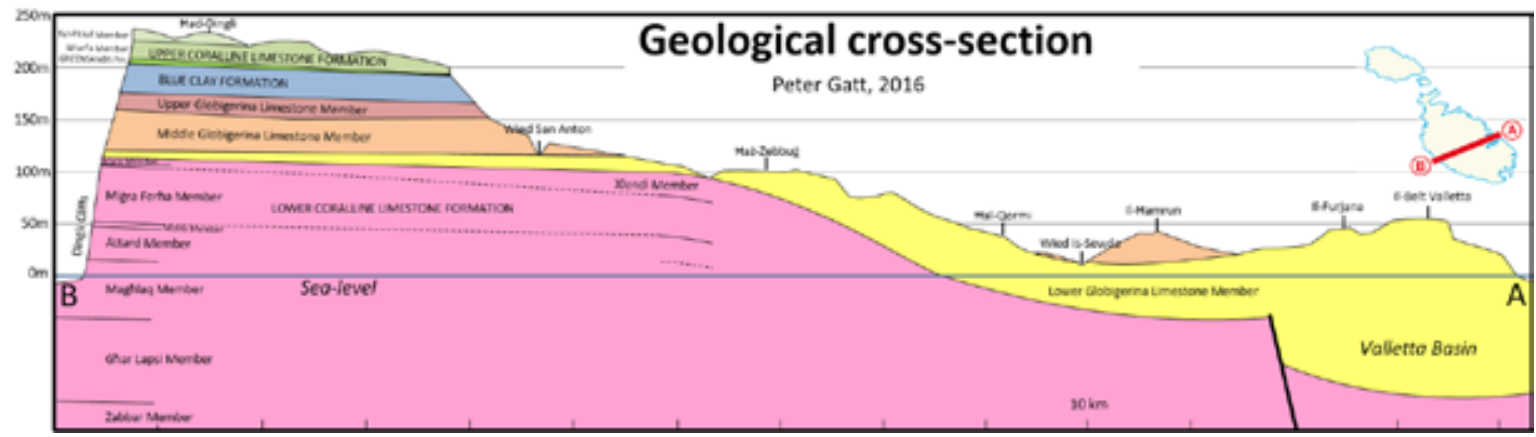

age is 28-23 Ma, and the maximum thickness is $162 \mathrm{~m}$. Several members are identified, as depicted on the geological section. This part of the stratigraphy is exposed in sea cliffs and hillsides in southern Malta and northern Gozo. Sea cliffs include arches; the Azure Window was a well-known example that collapsed in 2017. The Lower Coralline Limestone is a hard, compact rock with a pale grey colour. The uppermost member is relatively resistant and contains abundant marine fossils (including echinoid and bivalves), indicative of a shallow coral reef.

Four Miocene-age formations are represented in the Maltese archipelago. The lowermost component, the Globigerina Limestone Formation, has an estimated age of 23-14 Ma. The thickness varies between $207 \mathrm{~m}$ and $23 \mathrm{~m}$. Three subdivisions are recognised, of which the lowest member is the most widely developed. The limestone contains numerous marine fossils and is named after the abundance of the genus Globigerina (part of the protozoa classified

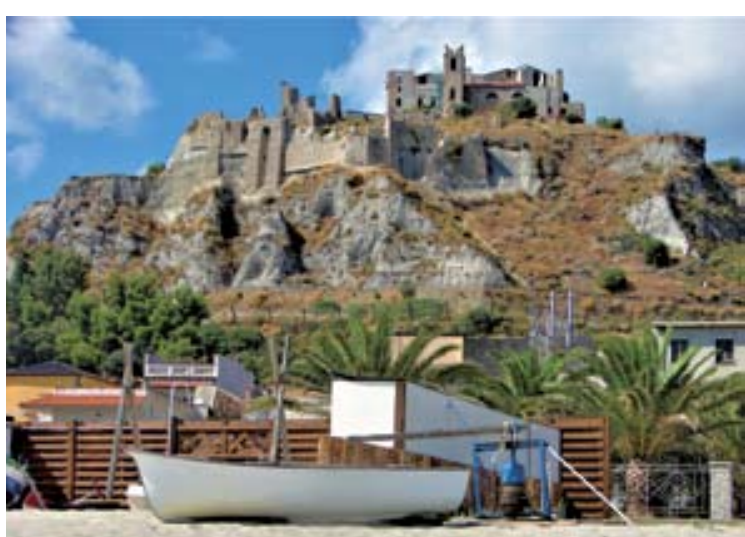
within the foraminifera order). The Globigerina Limestone
Geological section of Malta aligned with the Dingli Cliffs (southwest) and Valette (northeast) (source: Gatt ${ }^{13}$ ).

Most of the historical castles and fortifications on Gozo are constructed on resistant hills of the Lower Coralline Limestone.

The south-western coast of Malta reveals rugged sea cliffs and caves associated with the Lower Coralline Limestone.

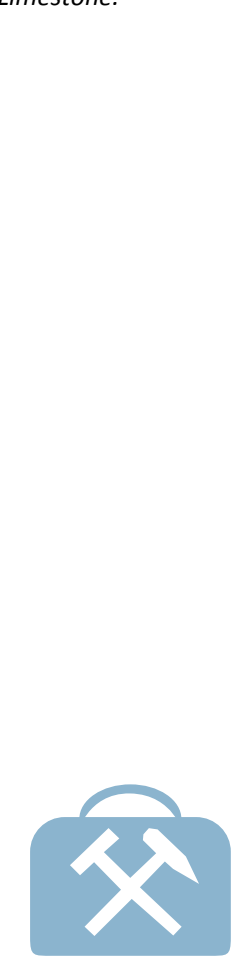


is overlain by the Blue Clay Formation. The estimated age is 15-10 Ma, and the thickness can reach $65 \mathrm{~m}$. The Blue Clay Formation is well exposed in the northwest of Malta but is absent from the eastern parts. The bluegrey clay or mudstone was deposited in a relatively deepwater environment and forms an impermeable layer. The overlying Greensand Formation is a glauconite-bearing, friable sandstone with an estimated age of 10-7 Ma. The maximum development of the sandstone is $11 \mathrm{~m}$, but this formation may be restricted to a thickness of a few $\mathrm{cm}$. The youngest of the Miocene formations is the Upper Coralline Limestone Formation. The estimated age is 7-5 Ma and the thickness approaches $140 \mathrm{~m}$. This pale grey limestone is found in many parts of Malta and northern Gozo. The vertical cliff faces of Comino Island are formed of the Upper Coralline Limestone.

The Upper Coralline Limestone formed during the Messinian stage of the Miocene epoch (7.246-5.333 Ma). This included an event that affected the entire Mediterranean. The Messinian salinity crisis (5.9-5.333 Ma) was a period of intense desiccation during which time the Mediterranean was separated from the Atlantic Ocean. Great thicknesses of evaporites accumulated in some of the Mediterranean Basins. ${ }^{10}$ The unusually shallow taper of the Mediterranean Ridge in the eastern Mediterranean may be related to the dominance of evaporites in an area subjected to extensional tectonics. ${ }^{4}$ The Messinian salinity crisis was followed by the Zanclean flood event (5.333 Ma), which defines the start of the Pliocene. This event records the refilling of the Mediterranean Basins, due to breaching of the Straits of Gibraltar.

The hillsides and lower sections of sea cliffs on the north coast of Gozo, near the village of Żebbug, consist of the Lower Coralline Limestone. The upper sections of the sea cliffs are capped by the Globigerina Limestone and the Upper Coralline Limestone; the Blue Clay and Greensands Formations are not developed in this area. The wave-cut platform at the foot of the cliffs at, for example, Xwejni Bay, contains small tidal pools that have been cut for collection of salt. The salt pans, or salinas, are of a type found throughout the Mediterranean. ${ }^{11}$ The hot, dry summers report exceptionally high evaporation rates. The salinas in Malta and Gozo, including at Xwejni Bay, are associated with natural wave-cut platforms developed on the Globigerina Limestone Formation. They typically occur in well-defined grabens. The sub-horizontal bedding assists with cutting of tidal pools.

During marine regressions that characterised the Upper Pleistocene (i.e. during the Ice Ages), the Maltese archipelago was connected to Sicily by an isthmus. The isthmus enabled access to land mammals from the European
The upper section of the cliffs at Xwejni Bay (pronounced Shway-nee), Gozo, consist of Miocene-age limestone.

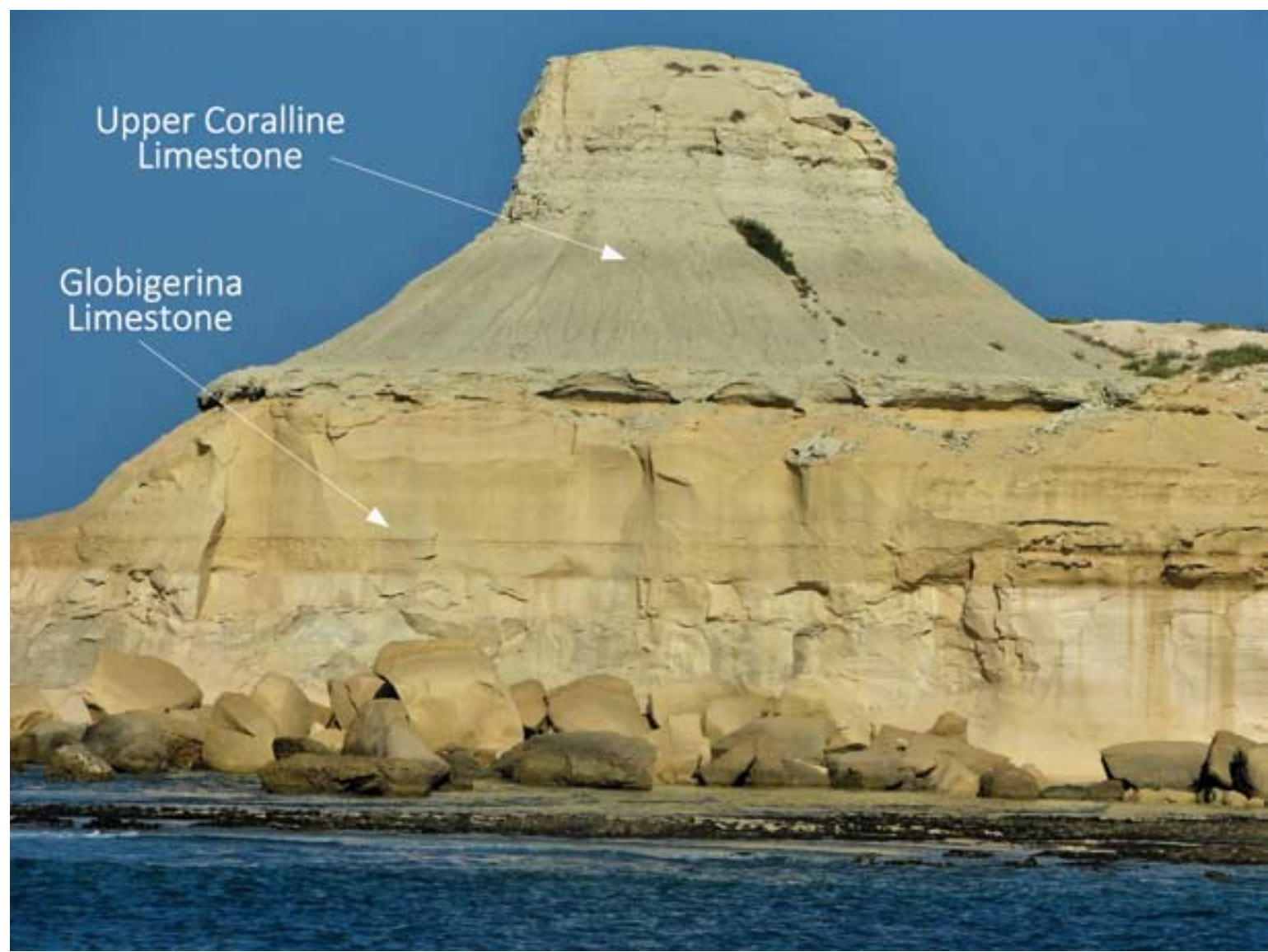




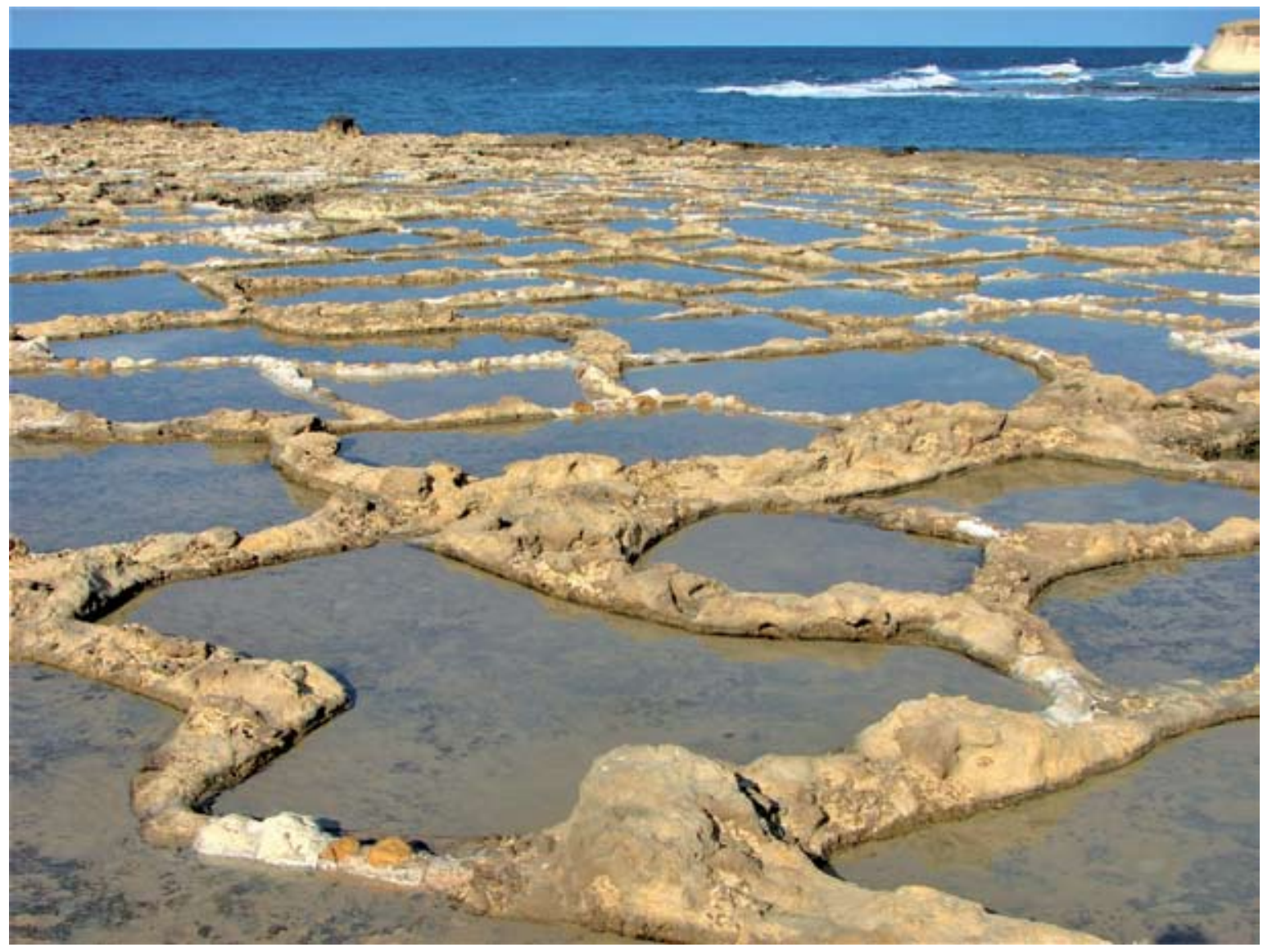

The wave-cut platform at Xwejni Bay consists of sub-horizontally bedded Globigerina Limestone that has been carved into tidal pools for collection of salt.

mainland. Mammals stranded in Malta at the end of the Last Glacial Maximum (20000 BP) were subjected to the competing phenomenon of "island dwarfism" (e.g., dwarf African Elephant) and "island gigantism" (e.g., Maltese Giant Dormouse). Fossils that include species unique to Malta have been excavated from Ghar Dalam, a cave located near the town of Birżebbuga in the southeast of
Malta. ${ }^{12}$ The cave, which is named after the Dalam family, has a length of $144 \mathrm{~m}$. The phreatic tube formed in the Globigerina Limestone beneath the water table. Ghar Dalam is Malta's most important natural monument and the name is applied by archaeologists and historians to a phase of prehistory. Fossils of extinct mammals include $d$ warf elephant, dwarf hippopotamus and dwarf bear. They

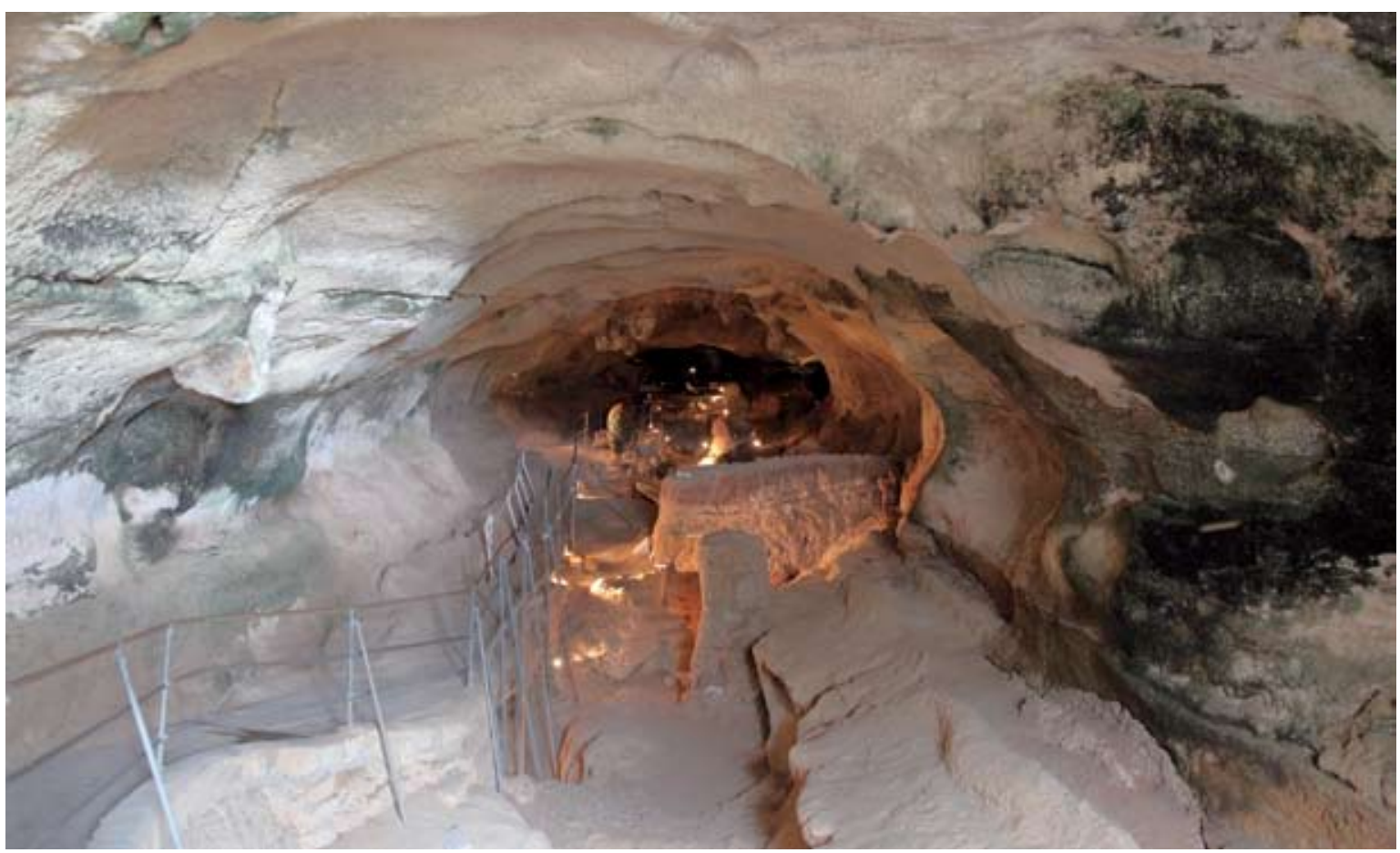

The Cave of Ghar Dalam, near Birżebbuga, is the most important natural history site in Malta (photo: Frank Vincentz, Wikimedia Commons).

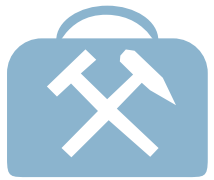


became extinct at approximately $10000 \mathrm{BP}$ (with the onset of the hotter and more humid climate of the Early Holocene). Fossils of an extinct deer (4000 BP) are also found here, as is evidence of the earliest human settlement in Malta, from the Chalcolithic period (7400 BP). A stratigraphic section at Ghar Dalam identifies six layers. From the surface downward these are: Domestic Animal Layer (0.74 m), Calcareous Sheet (0.06 m), Deer Layer (1.75 m; approximately 4000 BP), Pebble Bed (0.35 m; indicative of a flood event), Hippopotamus Layer (1.2 m; approximately 10000 BP), and a Bone Free Layer (1.25 m; > 10000 BP with plant impressions). Several caves with fossils of extinct mammals are aligned with the Mnajdra Fault, a prominent structure located near the megalithic temple

The Tarxien archaeological site, located close to Valetta, is one of the most widely visited of the six megalithic temples recognised in the Maltese archipelago. Standing stones

Information board at the Tarxien archaeologica site shows the three layers excavated.

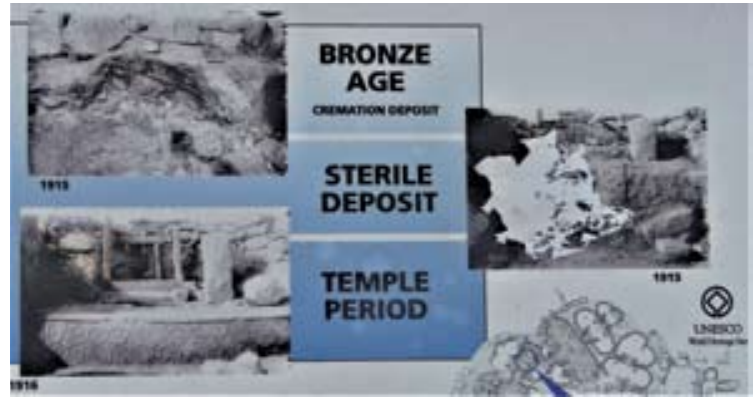

at Tarxien were excavated in 1915-1916. The megalithic temples predate Bronze-age relicts. The first of the megalithic temples to be excavated in the archipelago was, however, the Ggantija site (in 1827 and 1933-1959), which is in Gozo. The temples here are situated on a low plateau associated with the Lower Coralline Limestone. The other megalithic temples occur in southern Malta (Hagar Qim and Mnajdra) and northern Malta (Ta' Hagrat and Ta' Skorba). The megalithic temples typically face southeast and there is evidence of astronomical alignments. Most of the temples reveal a characteristic clover-shape with the inner parts reflecting the shape of the outer walls. The exceptional size of the standing stones has given rise to the description of this part of the Neolithic period as the Ggantija phase (3600-3000 BC). The name translates to "giantess" in the Maltese language. The temples reveal evidence of both religious and fertility symbolism, interpretations supported by the discovery of numerous figurines and statues at the Ggantija site.

The megalithic temples in Malta and Gozo are the second oldest manmade structures in the world (the oldest is Göbekli Tepe, in central Turkey). Similar features are not known from elsewhere in the Mediterranean. The temples are protected in archaeological sites that include walkways and detailed information boards. Exposure to the atmosphere has resulted in some weathering of the standing stones

Standing stones at Tarxien are part of a megalithic temple.

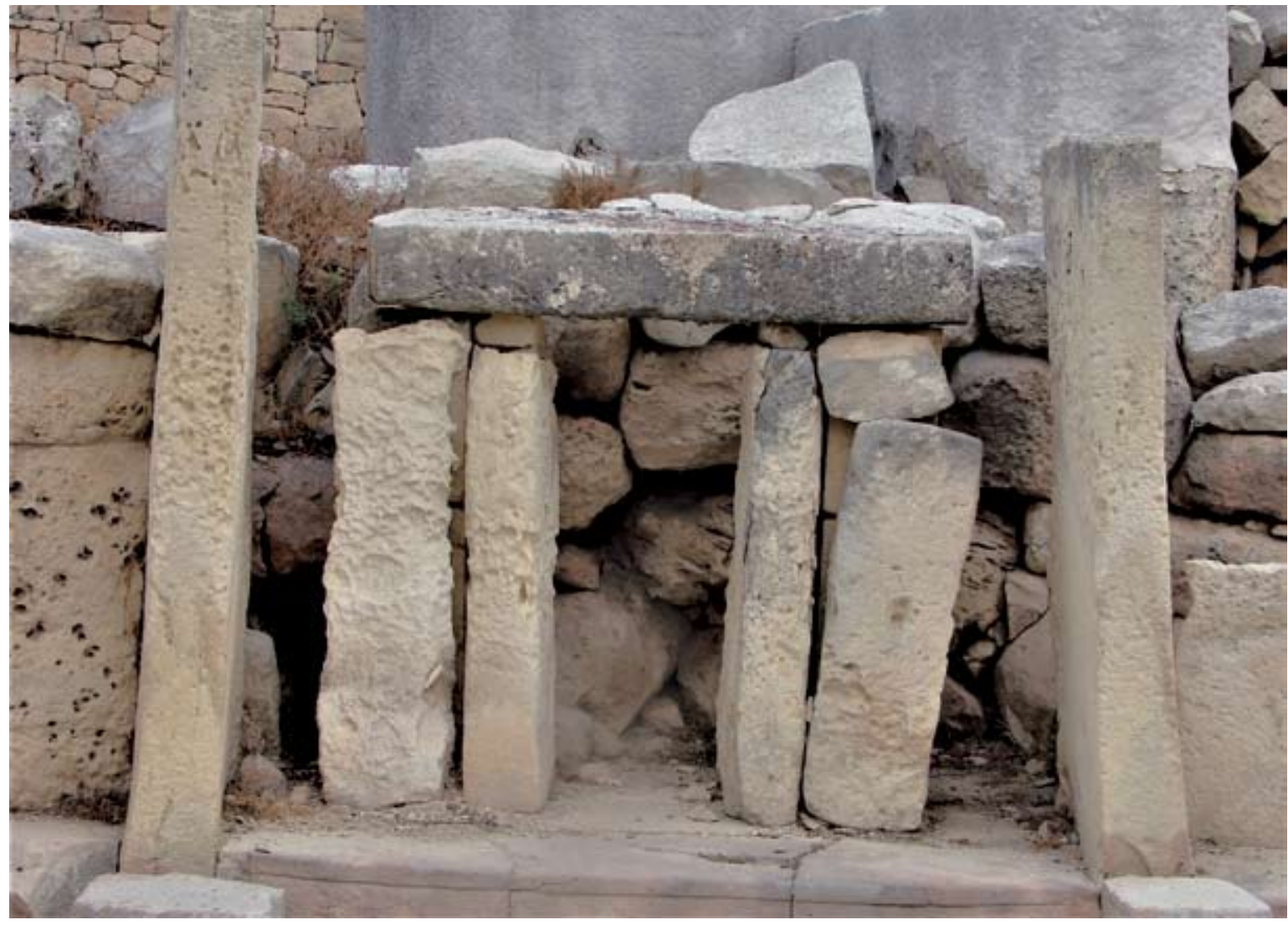




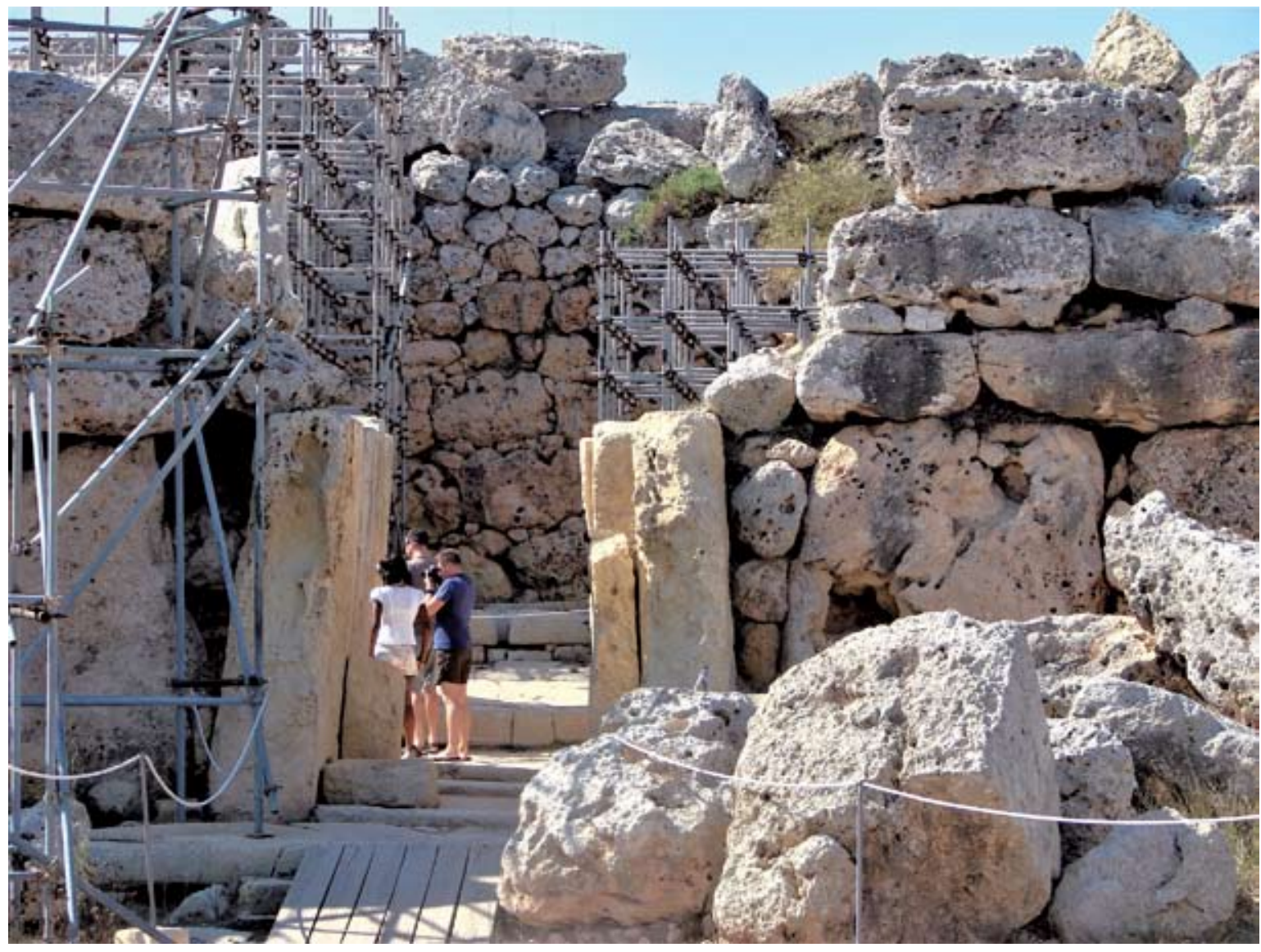

The massive nature of the Ggantija archaeological site, Gozo, is apparent from both standing stones and perimeter walls. Ggantija is constructed of the resistant, Oligoceneage Lower Coralline Limestone.

(or menhirs), e.g., surface flaking and honeycombing, although most are remarkably well preserved. For this reason, the megalithic temples at Hagiar Qim and Mnajdra are enclosed by extensive tented structures. The latter two sites occur approximately $500 \mathrm{~m}$ apart in an area of extensive rock pavements of the Globigerina Limestone Formation.
Hagiar Qim translates to Standing or Worshipping Stones. The site was excavated in 1839-1840 and includes a Main Temple Complex and three subsidiary temples. The standing stones consist of the relatively soft Globigerina Limestone. Building stones were derived from multiple sites, not only locally. The standing stones are arranged in circular

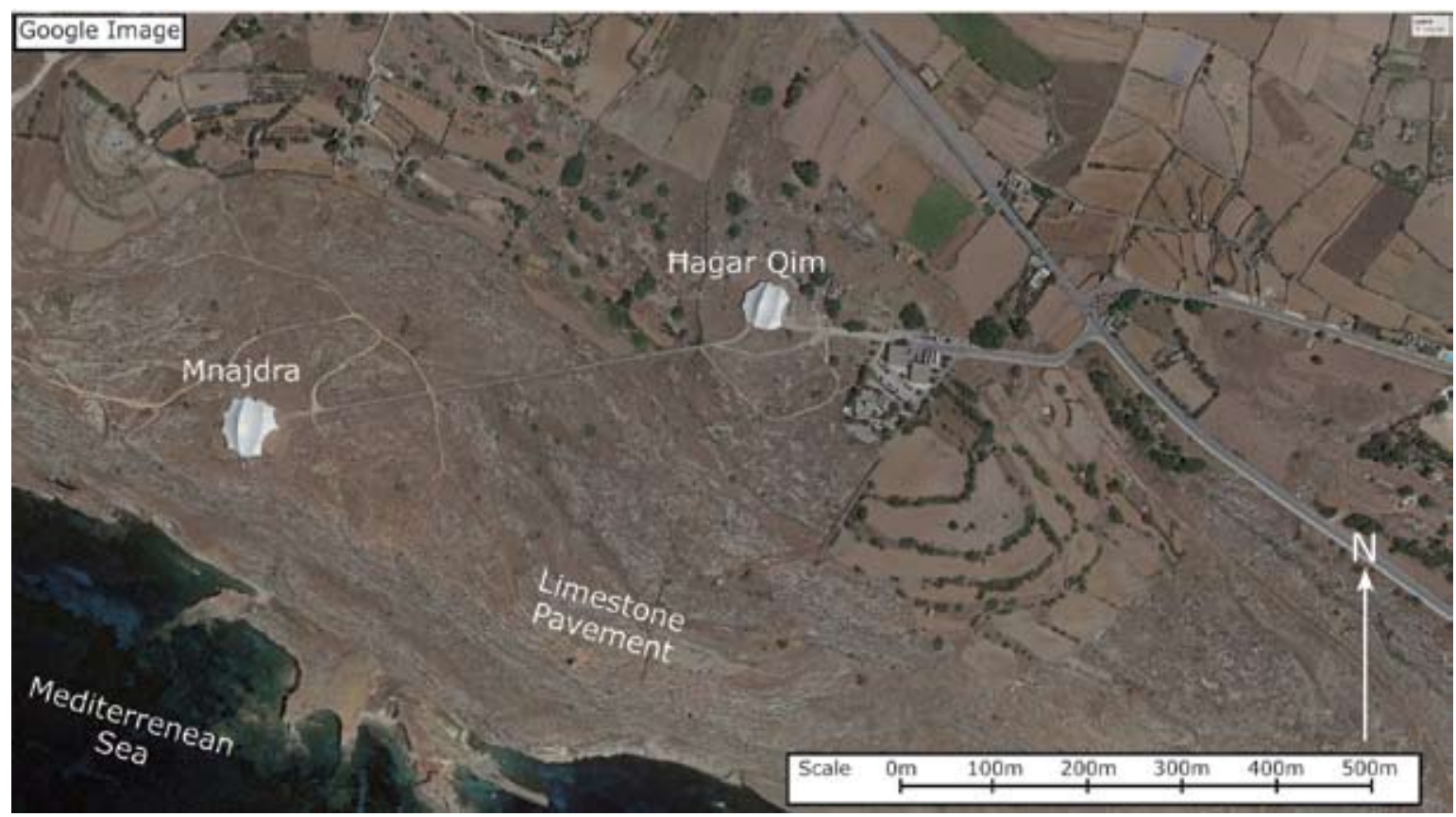

Image showing the tented structures that protect the megalithic temples of the Hagiar Qim and Mnajdra archaeological sites, southern Malta. The rock pavement is made of Globigerina Limestone (source: Google Earth). 
View showing the rock pavement and NW-SE strike of the Globigerina

Limestone Formation, near Haǵar Qim.

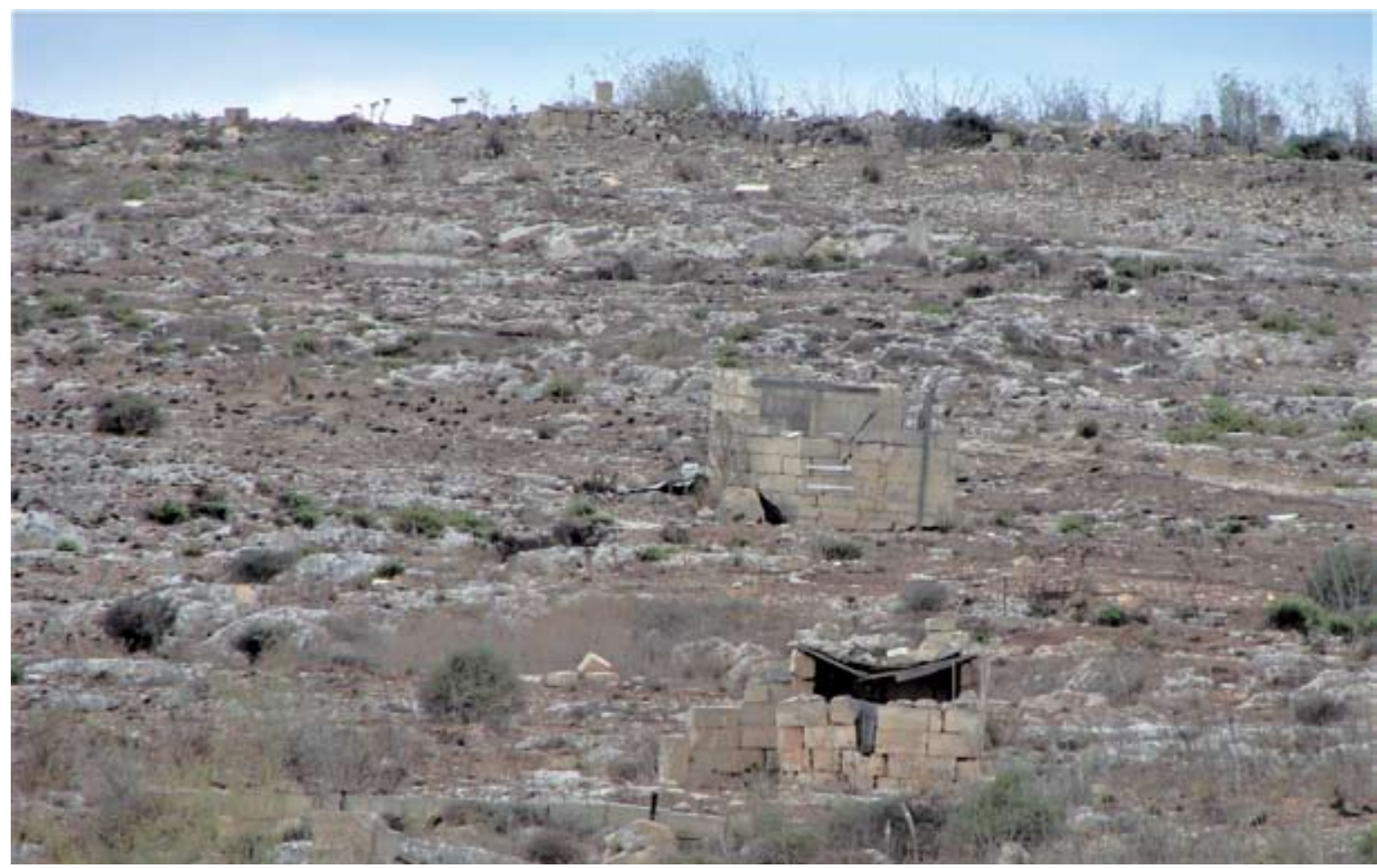

The tented enclosure at Mnajdra.

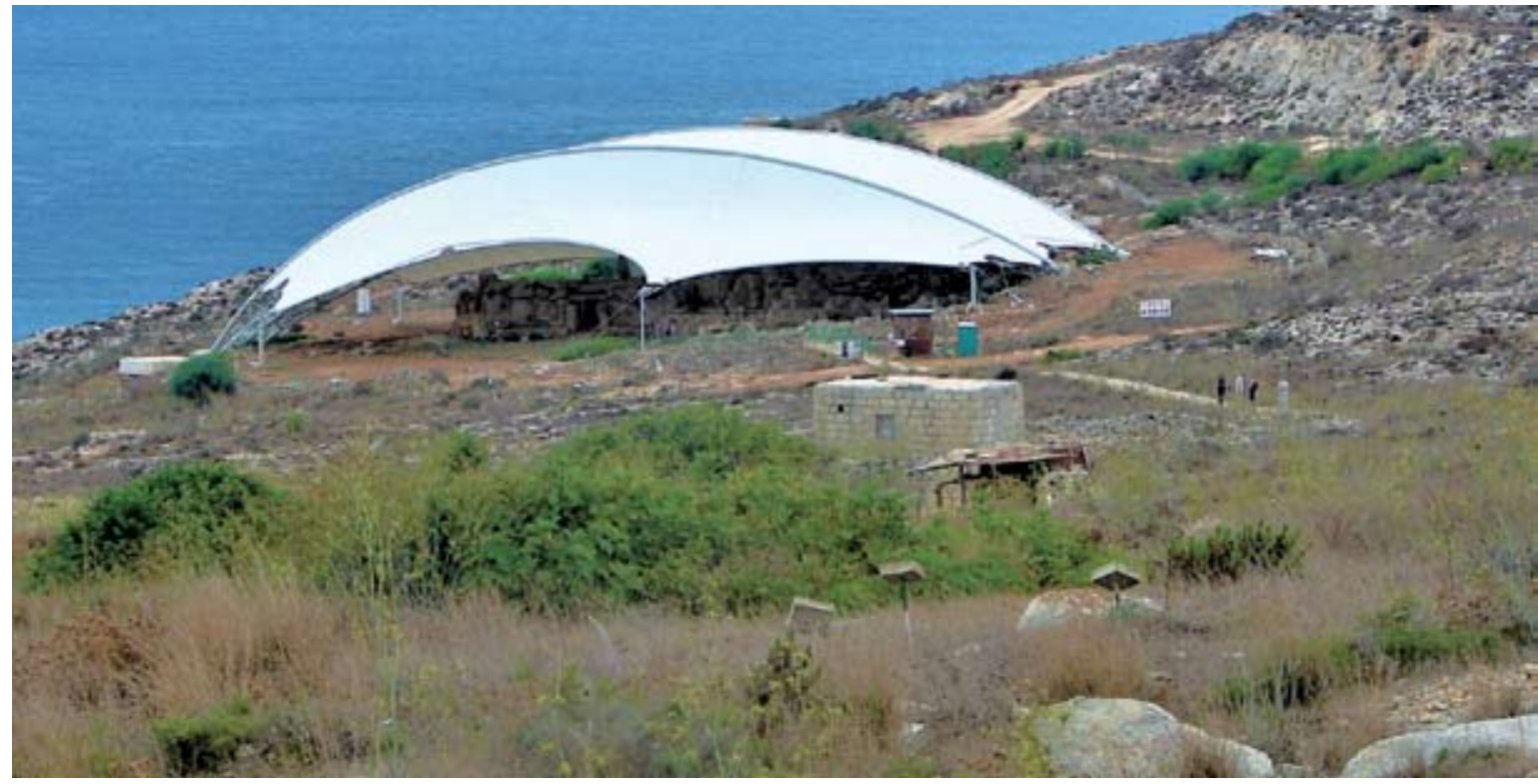

The megalithic structures

in the Main Temple

Complex, Hagiar Qim,

consist of a circula arrangement of standing stones.

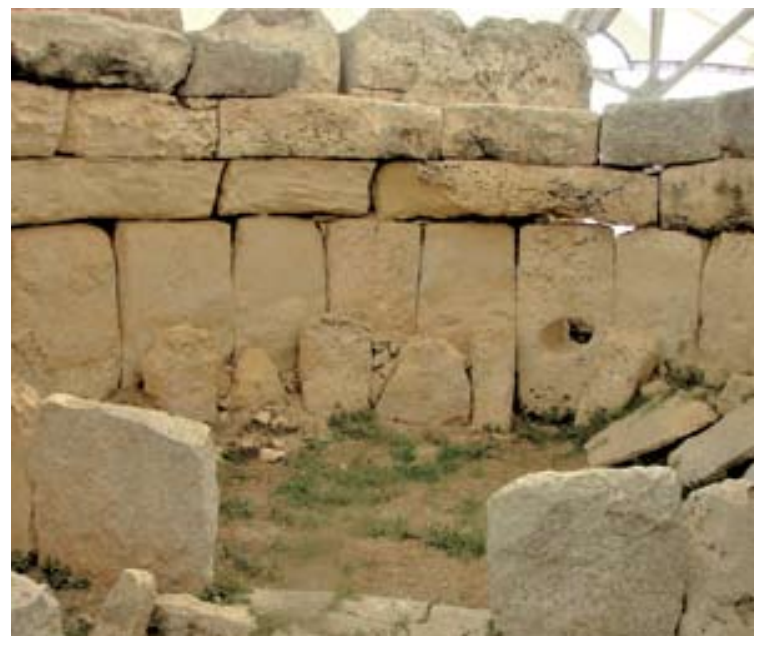

patterns and access to the central parts of the temples is restricted to "porthole entrances", i.e. stone slabs pierced with rectangular apertures that form narrow passageways. The courses located above the upright slabs are interpreted as remains of corbelled roofs. The largest of the upright standing stones has a height of $5.2 \mathrm{~m}$ and weighs 57 tonnes. The megaliths are thought to have been transported by use of levers and with spherical rocks acting as ball bearings. Clusters of medium-sized standing stones at Hagar Qim are interpreted as dwelling houses. Four large, rectangular monoliths are an additional feature. Most standing stones are positioned adjacent to rock-cut channels and walls with extensive foundations (soil deposits are recent). Features 


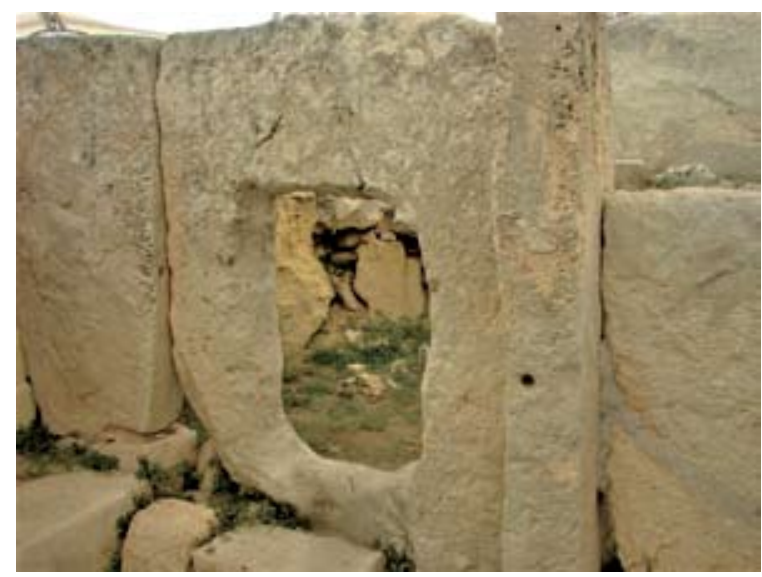

The temple complex

includes narrow porthole

entrances.

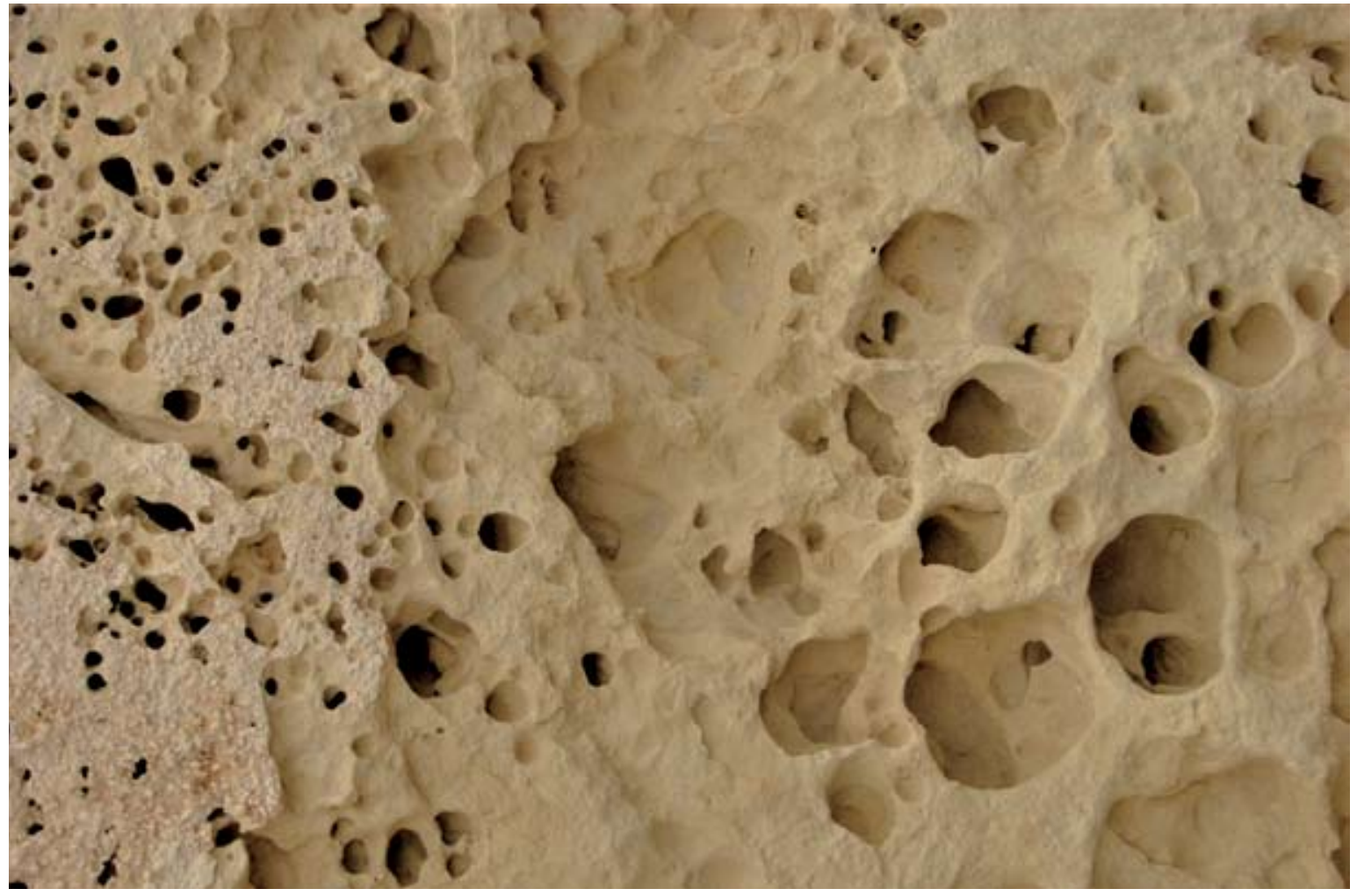

Extensive honeycomb weathering in a standing stone. All structures at Hagiar Qim are built of the Miocene-age Globigerina Limestone.
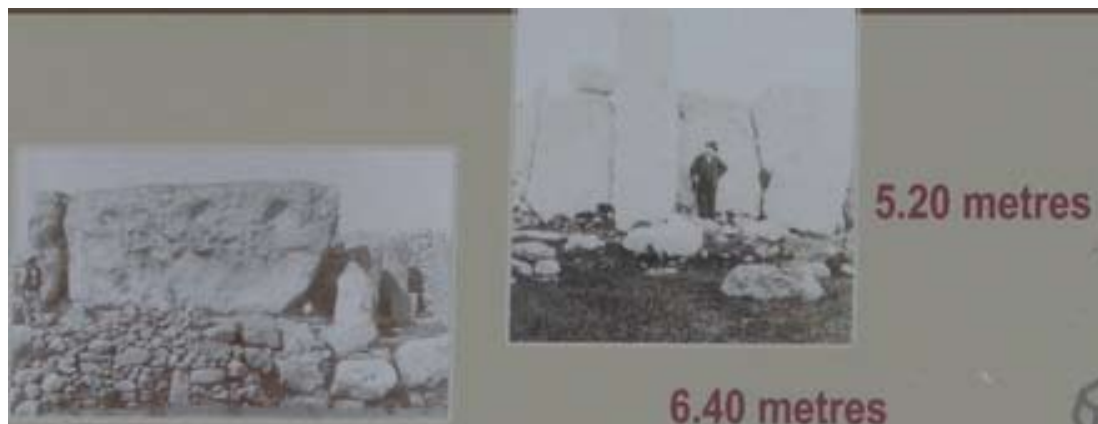

\subsection{0 metres}
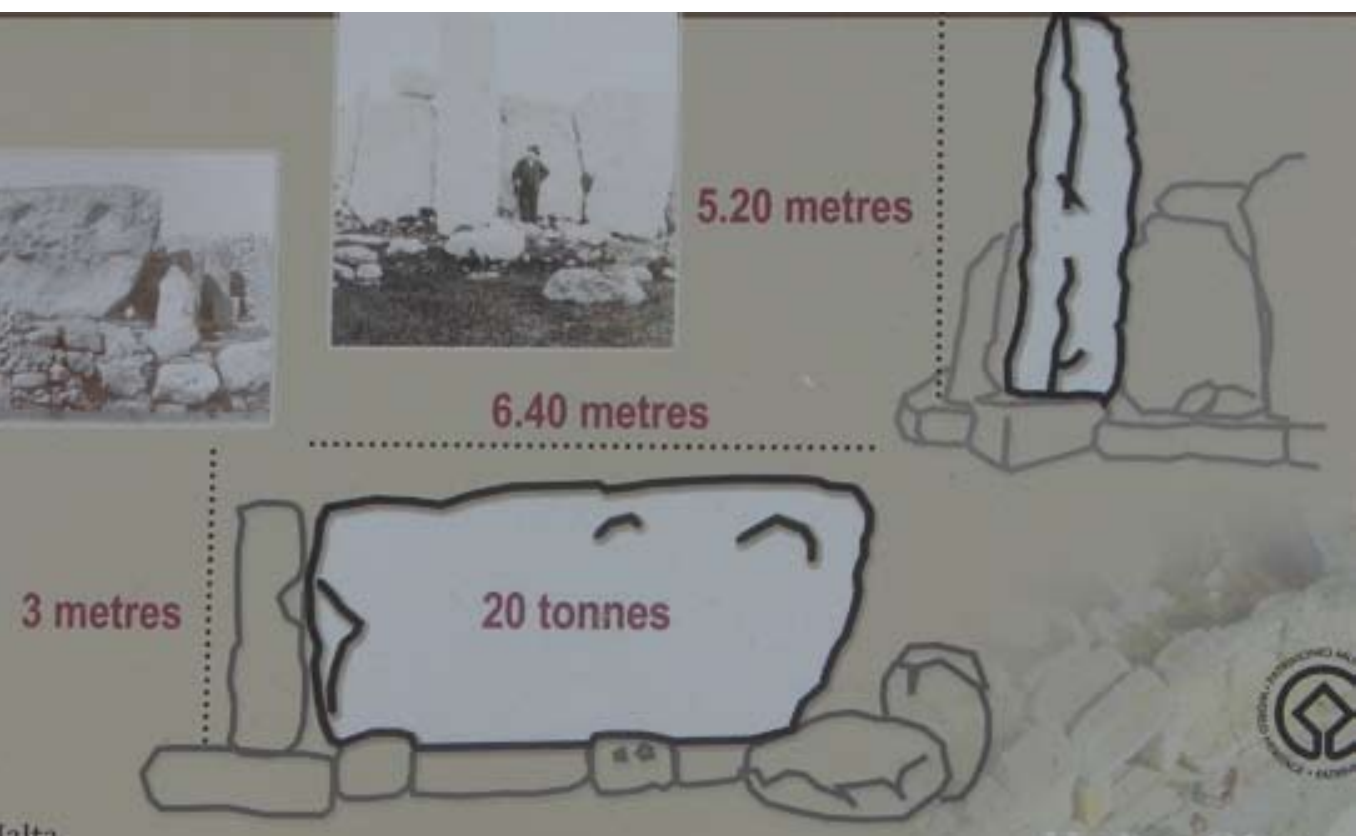

Information board at the Hagiar Qim archaeological site.

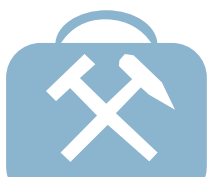



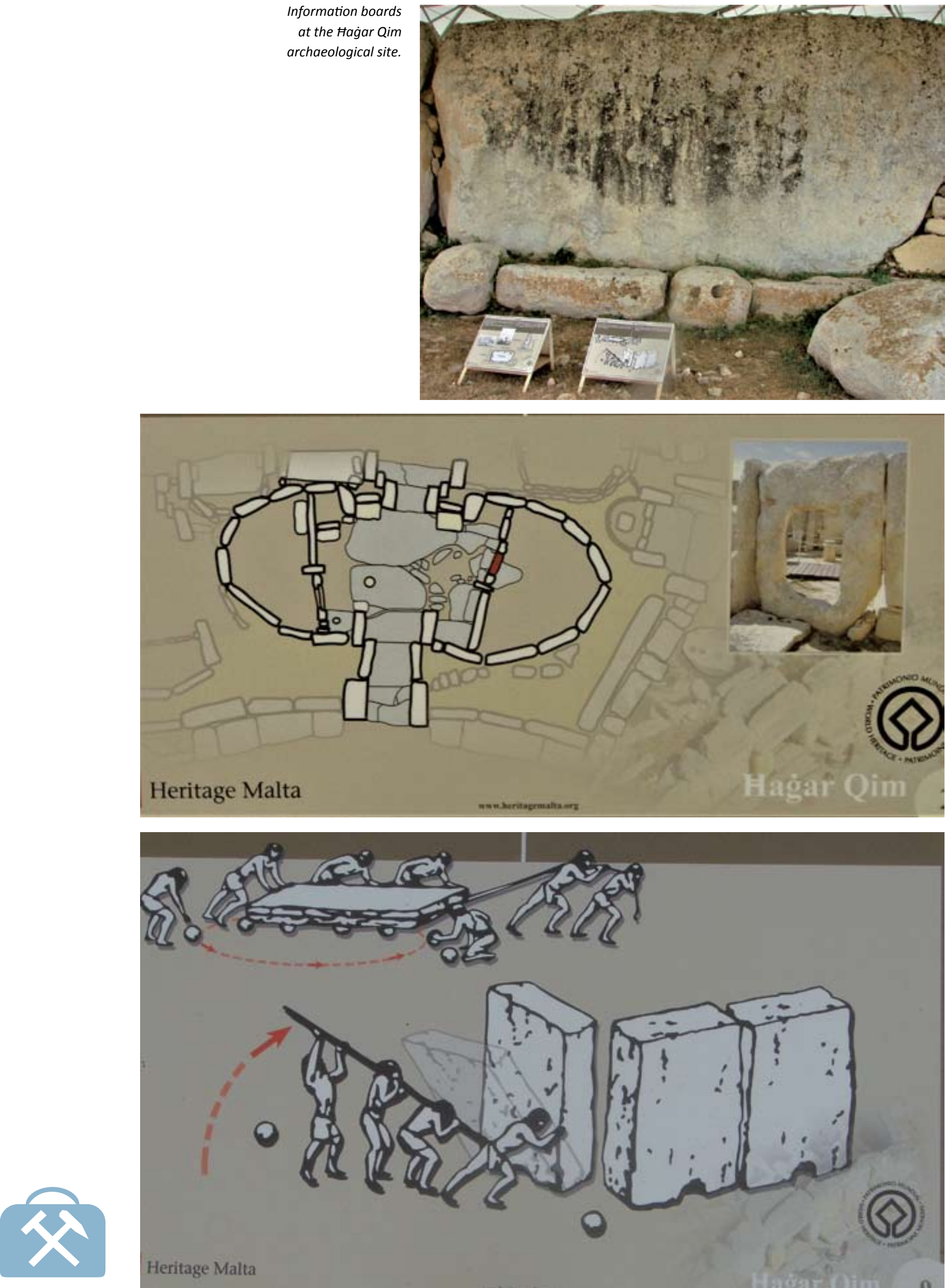

(8)

Heritage Malta 


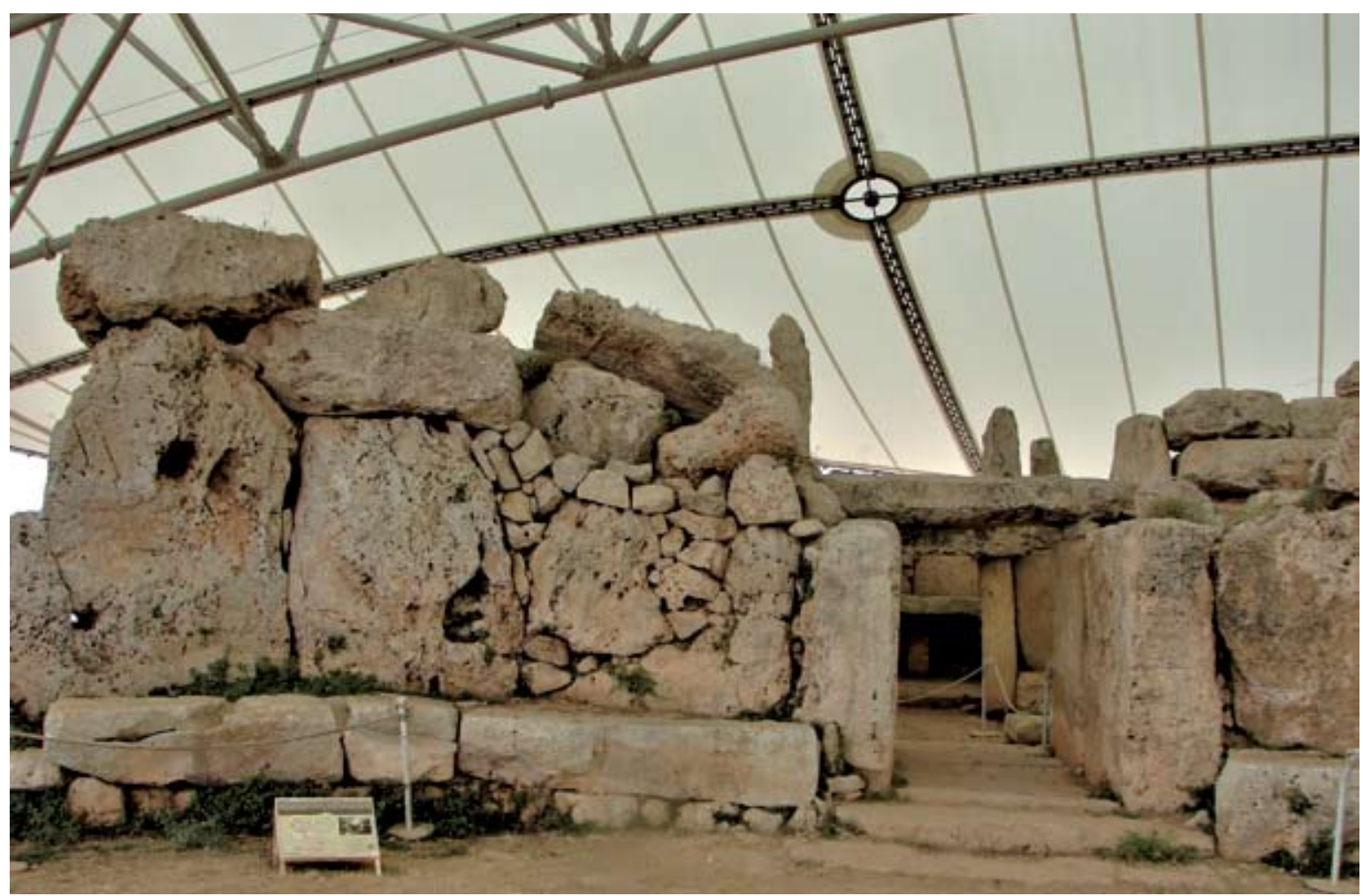

Outer walls of the South Temple at the Mnajdra archaeological site are constructed of massive blocks of Lower Coralline Limestone.

located southwest of the archaeological site include a concentration of cylindrical holes drilled into the basement rock and large cavities.

The Mnajdra archaeological site reveals multiple temples, including the South Temple, which is aligned such that at the solstices only a narrow beam of light enters the building. Sections of walls have been shown by archaeologists to have been constructed using a technique known as "header and stretcher", i.e. stones are positioned alternatively with faces and edges outward. The perimeter walls and outer parts of the temples at Mnajdra are built of the relatively hard Coralline Limestone. Usage of the softer Globigerina Limestone is restricted to the inner parts of temples where many of the stones have been intricately carved.

The Hal Saflieni Hypogeum (meaning underground in Greek), located in Paola, a few kilometres south of Valletta,

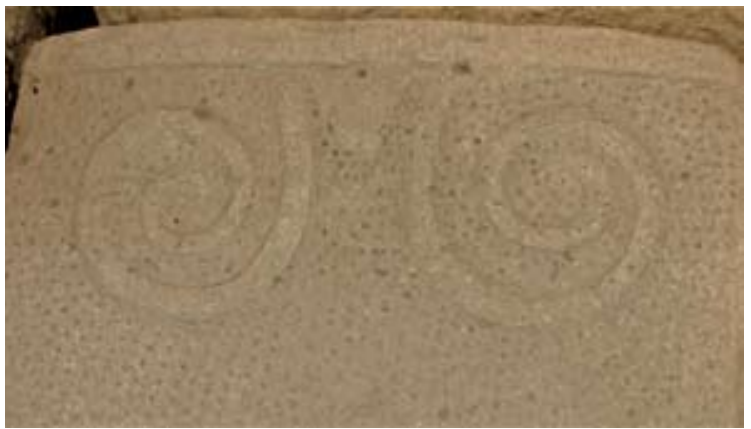

The Globigerina Limestone used in the inner parts of megalithic temples at Mnajdra is intricately carved.
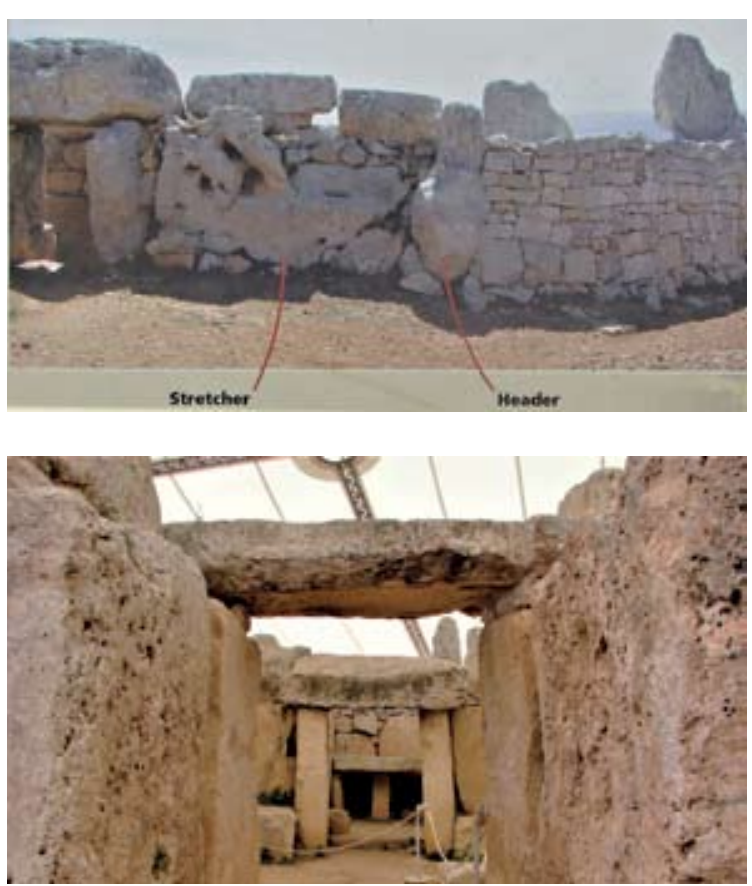

Information board showing usage of "stretchers" and "headers".

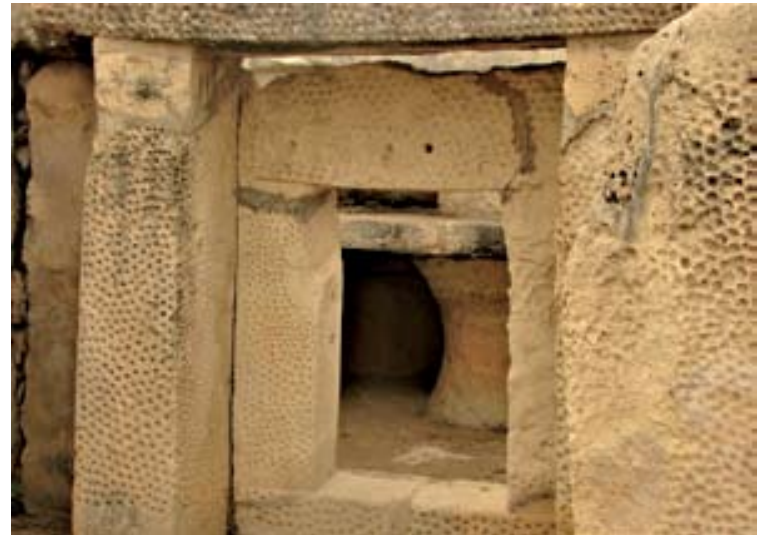

The softer Globigerina Limestone is used for the inner parts of the temples at Mnajdra.

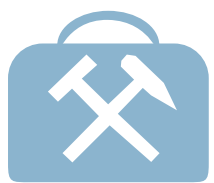




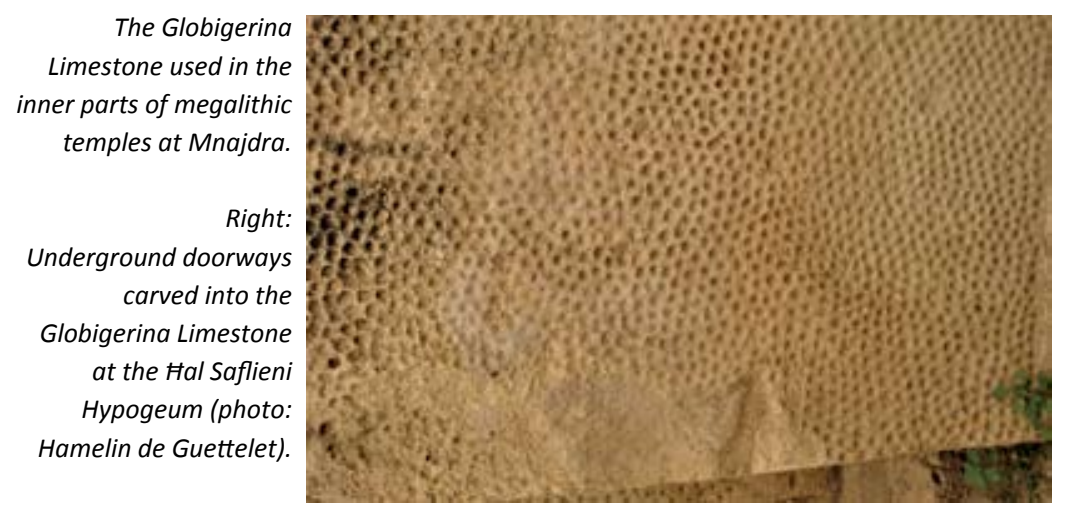

is a subterranean complex of temples with an approximate age of 3200 BC. The Hypogeum is constructed into the Globigerina Limestone; three superimposed levels have been excavated. The Hypogeum was a sanctuary and necropolis, with remains of more than 7000 humans recovered, and is considered as part of the Ggantija historical period, i.e. associated with the surface temples.

All photographs, unless otherwise referenced, are by the author.

* Department of Geology, Rhodes University, Grahamstown (rnscoon@iafrica.com)

\section{References:}

1. Pedley, H.M., House, M.R. and Waugh, B. (1978). The geology of the Pelagian blocks: The Maltese islands. In A.E.M. Nairn, W.H. Kanes \& F.G. Stehli (Eds.). The ocean basins and margins, 4B: The western Mediterranean ( $p$. 417-433). London, England, Plenum Press.

2. Pedley, H.M., Clarke, M.H. and Galea, P. (2002). Limestone isles in a Crystal Sea: The geology of the Maltese islands. San Gwann, Malta, Publishers Enterprises Group.

3. Hsü, K.J. (1977). Tectonic evolution of the Mediterranean Basins. In: Nairn, A.E.M., Kanes, W.H. and Stehli, F.G. (Eds.) The Ocean Basins and Margins Volume 4A: The Eastern Mediterranean. Plenum Press, New York, and London, 29-76.

4. Jolivet, L. et al. (2013). Aegean tectonics: Strain localisation, slab tearing and trench retreat. Tectonophysics, 597-598, 1-33.

5. Panza, G.F. and Suhadolc, P. (1990). Properties of the lithosphere in collisional belts in the Mediterranean - a review. Tectonophysics, 182, 39-46.

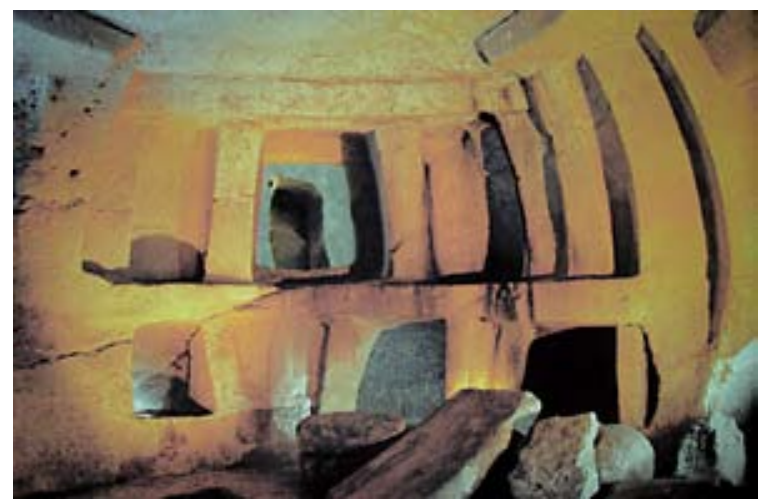

6. Kilburn, C.J. and McGuire, W.J. (2001). Italian Volcanoes. Harpenden, Terra Publishing, $174 p$.

7. Civetta, L., Comette, Y., Crisci, G. and Gillot, P.Y. (1984). Geology, geochronology, and chemical evolution of the island of Pantelleria. Geological Magazine, 121, 541562.

8. Mowbray, J.H. (1909). Italy's Great Horror of Earthquake and Tidal Wave. National Publishing, Philadelphia, 358 p (urn: colic: record: 1047490596).

9. Piatanesi, A. and Tinti, S. (1998). A revision of the 1693 eastern Sicily earthquake and tsunami. Journal of Geophysical Research, 103, 2749-2758.

10. Cita, M.B. (2006). Exhumation of Messinian evaporites in the deep-sea and creation of deep anoxic brine-filled collapsed basins. Sedimentary Geology, 188-189, 357378.

11. Gauci, R., Schembri, J.A. and Inkpen, R. (2017). Traditional Use of Shore Platforms: A Study of the Artisanal Management of Salinas on the Maltese Islands (Central Mediterranean). SAGE Open 7(2):215824401770659, DOI: $10.1177 / 2158244017706597$.

12. Fabri, N. (2007). Ghar Dalam: The Cave, the Museum, and the Garden: Birżebbuga. Malta: Heritage Books. DOI: 10.13140/RG.2.2.11118.20804

13. Gatt, P. (2016). Map of the Maltese Islands with geological cross section and geological overview. DOI: 10.13140/RG.2.2.11118.20804 


\section{student awards}

\section{GSSA Annual Student Award Winners}

The Fellows Committee of the GSSA annually manages and adjudicates the GSSA Awards Program, with winners normally being announced in the mid-year AGM and the November Fellows Dinner. Because of the Covid-19 pandemic, this year the AGM was a virtual event at which no awards were announced, and the Fellows Dinner has been cancelled. A suitable time and venue for presenting the awards in person is still to be determined. The student winners are announced below and are congratulated, along with their supervisors.

Awards are made for the year prior to the year in which submissions are adjudicated.

The John Handley Award for the best MSc thesis and the Corstorphine Medal for an outstanding MSc thesis of high international standard is awarded to Ms. Lechelle Goslin of the University of the Witwatersrand for a thesis entitled 'Deformation and Partial Melting in the Central
Zone of the Damara Zone, Namibia', supervised by Paul Nex and Robert Bolhar.

The Haughton Award for the best BSc Honours thesis goes to Ms. Ayesha Jogee of the University of the Witwatersrand for a thesis entitled 'Unravelling the Petrogenesis of Mafic Orbicules of the Koperberg Suite and their Metallogenetic Links to Cu Mineralisation', supervised by Grant Bybee and Paul Nex.

The SACNASP Award (Best $4^{\text {th }}$ Year Student) goes to Ms. Sinelethu Hashibi of the University of Cape Town for a thesis entitled 'A Comparison of Kimberlite Indicator Minerals from Two Kimberlites of Widely Varying Diamond Grade from the Barkly West Region, Northern Cape, South Africa', supervised by Phil Janney.

Congratulations to the award winners and their supervisors. Thanks also to department heads and supervisors for submitting their nominations. As has been the case for the last several years, the submissions were all of very high quality.

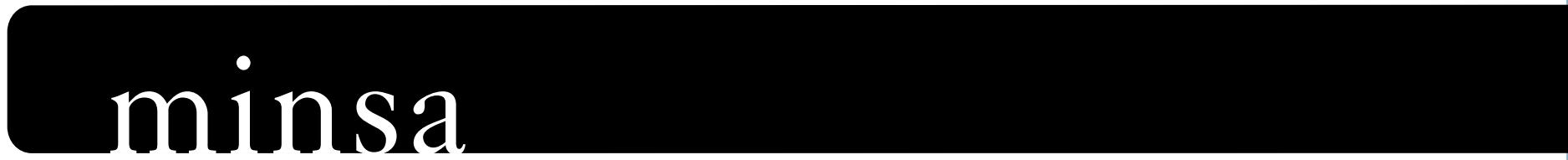

On the $16^{\text {th }}$ of September, MINSA hosted its AGM via Zoom and invited Dr Louis Cabri as the guest speaker. Dr Cabri spoke on his "Reflections on mineralogy over the past seven decades", chronicling his involvement in projects in both Africa and Canada, with a few adventures thrown in for good measure. Attendance peaked at 43 listening in on Dr Cabri's talk, and 21 members attended the AGM proper, which kicked off afterwards. The executive committee remains largely unchanged and Igor Tonžetić takes over from Bertus Smith as the chairperson for the 2020-2021 term.

Following on from a successful AGM, MINSA also hosted a two half-day online symposium on the $20^{\text {th }}$ and $21^{\text {st }}$ of
October. The themes for the presentations were based on the two most recent issues of The Geode: "Novel, interesting and under-utilised techniques" and "Samples, sampling and sample preparation". The nine presenters covered a variety of topics and participants numbered around 120 , with at least a third being students.

To wrap up 2020, MINSA will follow last year's hugely popular talk marking the $150^{\text {th }}$ anniversary of the Periodic Table with a virtual phytoremediation presentation celebrating the 'Year of the Plant' in early December. Our end-of-year Geode edition on 'Sampling and Sample Preparation' will also be issued in December. 


\section{GSSA events 2021}

GSSA Events from January 2021 to November 2021

The provisional GSSA events schedule for 2021 includes scientific, economic and developmental offerings, and more detail will be circulated closer to the time of each event. 2020 has been a year of major change for meetings and conferences, with a successful transition from contact to online meetings thanks to the efforts of the
GSSA Meetings Committee and the office staff. 2021 will no doubt see additional change with further transition to 'hybrid' events, probably in the second half of the year. The major conference of the year will be Geocongress in July, but exact dates are not yet set because university calendars are not yet final. The lunchtime lecture series will continue, though scaled back from the frequency organised during hard lockdown.

\begin{tabular}{ll}
\hline DATE & EVENT \\
\hline 8 February -1 March & Drilling Methods and Techniques in Resource Exploration \\
$(4 \times 1 / 2$ days $)+$ self-study & \\
\hline 26 February & REl colloquium \\
15 March & CPD Workshop \\
\hline 24 March & Ensuring a safe and inclusive mining workplace \\
\hline 16 April & Clean \& Green Day \\
\hline $18-19$ May & Economic Analysis in Minerals \\
\hline 25 June & Gold \& Silver Day \\
\hline July & Foundations for a Geological Career \\
\hline $6 \times 1 / 2$ day) June-July & Geocongress 2021 \\
\hline 5 August & Geotechnical Workshop \\
\hline $20-22$ August & Advanced Structural Geology/Field Trip \\
\hline 27 August & ESG Workshop \\
\hline $7-28$ September & Drilling Methods and Techniques in Resource Exploration \\
\hline $4 \times 1 / 2$ days $)+$ self-study & \\
\hline 8 October & 3-D Geological modelling \\
\hline 13 October & Coding/Programming 101 \\
\hline 19 October & CPD Workshop \\
\hline 11 November & African Exploration Showcase \\
\hline 12 November & \\
\hline
\end{tabular}

The GSSA reserves the right to make changes to the calendar.

VP Meetings - Noleen Pauls: noleen@fastmail.fm 


\section{Request for applications to the \\ Research, Education and Investment (REI) Fund of the GSSA}

\section{Closure date for applications: 31 January 2021}

The GSSA Research, Education and Investment Fund (REI Fund) is inviting applications from GSSA paid upmembers (including current post-graduate student members) for grants from the Fund, to be received at the GSSA office not later than 31 January 2021. Applications can be made using the prescribed application

form available on the GSSA web site (www.gssa.org.za) or see the link below for the online form:

\section{https://www.cognitoforms.com/GeologicalSocietyOfSouthAfrica/ researcheducationandinvestmentfund}

Supporting information required with each application includes a short description of the project, brief motivation for research and funding requested, a budget describing how funds will be used, and a letter of support from research supervisor

(in cases where the applicants are post-graduate students).

Grants are intended to support a variety of earth science research costs, including analytical and field costs, conference attendance, and publication costs. Projects that promote and support earth science awareness such as geoheritage, geotourism and geo-education may also be supported. Expenses related to (annual) registration and tuition fees, textbooks, accommodation, etc. required at Higher Education institutions are not covered. Members enrolled at non-South African universities are not eligible to apply for financial support.

In particular we welcome applications from post-graduate student members and would appreciate it if Heads of Departments at Higher Education Institutions and their staff would inform their students of this opportunity. Grants are usually limited to R20 000 per application but well-motivated applications for larger amounts are also welcome. All applications will be judged on merit and/or the importance to the Society in promoting its image. Note that grants are only awarded to members/student members in good standing.

Applications are screened by the REI Fund Committee during February with input and ratification by the GSSA Management Committee and Council, respectively. In evaluating the applications and recommendations, the Committee considers the merit of each application, and depending on the amount of money available for that year, makes a final decision on the allocation of grants for that year. The decision of the Committee is final and no further correspondence on the matter will be entertained. By following this procedure it is anticipated that applicants will be informed by mid-March 2020 whether or not their applications are successful. Recommendations made by the Committee require Council approval, which may delay notifications.

The current members of the REl Fund Committee are: Reinie Meyer (Chairman), Frank Gregory, Bertus Smith, Rob Ingram, Derek Kyle, Steve McCourt, Richard Viljoen, Mike Wilson, Grant Bybee and two office bearers of the Society who have ex officio status, namely the President (Sifiso Siwela) and the Executive Manager (Craig Smith). 


\section{classifieds}

\section{SC \\ StereoCore}

Photogrammetric digital core logging

Customisable logging of point, interval and structure data

Auditable image-based measurements (depths, angles etc.)

Simple to learn, easy to use

\section{www.stereocore.net}

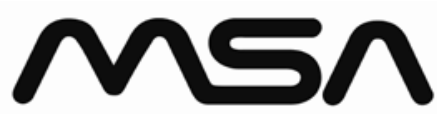

THE MSA GROUP

Specialist Consultants and Contractors to the Resource Industry

Tel: $\quad+27(0) 118804209$

Fax: $\quad+27(0) 118802184$

PO Box 81356, Parkhurst, 2120, South Africa

Email: info@msagroupservices.com www.msagroupservices.com

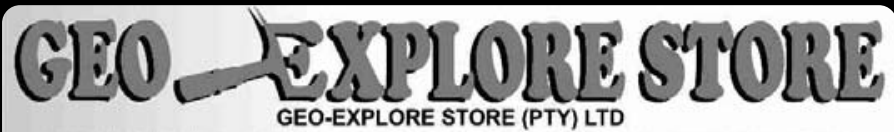

SUPPLIERS OF GEOLOGICAL \& EXPLORATION EQUIPMENT

\section{Denis Blewett}

Cell: 0827447594
67 Watt St

Route 24

Meadowdale Edenvale
Tel: +27 (0) 113925324

Fax: +27 (0) 865807392 denis@geoexplorestore.co.zo www.geoexplorestore.co.za

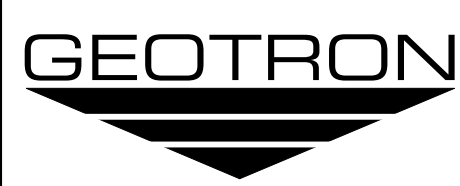

MANUFACTURERS \& SUPPLIERS

- Manufacturers of Geophysical equipment

- Suppliers of Earth Science Hardware \& Software

10 Jeppe St, Potchindustria

Tel: +27 (18) 2944004

South Africa Cell: +27 (0) 837500944 e-mail: ray@geotron.co.za

\section{MINROM}

managing mineral resource risk

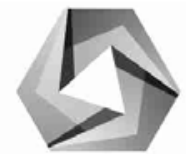

\begin{tabular}{lr}
\hline - Exploration Management & $\begin{array}{r}\text { www.minrom.co.za } \\
\text { info@minrom.co.za }\end{array}$ \\
\hline - Competent Person's Reports & $\begin{array}{r}13 \text { Esdoring Nook, } \\
\text { Highveld Technopark, } \\
\text { - Project Due Diligence }\end{array}$ \\
\hline
\end{tabular}

\section{}

Metallurgıcal consultancy в Laboratories

Our four-in-one solution.

We do your test work, interpret it, model it

and integrate the results in metallurgical designs. Modderfontein, 1609, South Africa ISO

CM Solutions is an ISO 9001:2008 accredited company
C 0824412788

Econsultants@cm-solutions.co.za W www.cm-solutions.co.za

Pinelands Office Park

Pinelands Office $P$
T 0116080019

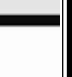

\begin{tabular}{|c|c|c|}
\hline \multicolumn{3}{|c|}{$\begin{array}{l}\text { Structural-Economic Geologists with } 20 \text { years } \\
\text { of specialised consulting services to over } 150 \text { clients }\end{array}$} \\
\hline \multicolumn{3}{|c|}{$\begin{array}{c}\text { 3D Geological Modelling } \\
\text { Structural Interpretations } \\
\text { Geophysical Data Interpretation } \\
\text { Review of Mining and Exploration Projects } \\
\text { Analysis of Structures for Geotechnical Design }\end{array}$} \\
\hline $\begin{array}{l}\text { Dr lan Basson } \\
\text { Ph.D. Struct. Geol. } \\
\text { Pr. Nat. Sci., FGSSA }\end{array}$ & www.tect.co.za & $\begin{array}{r}+27217019463 \\
+27823348007 \\
\text { info@tect.co.za }\end{array}$ \\
\hline & Group & $\begin{array}{l}\text { MINING \& } \\
\text { EXPLORATION } \\
\text { CONSULTANTS }\end{array}$ \\
\hline $\begin{array}{l}\text { •Exploration Programme } \\
\text { Management }\end{array}$ & •Mining Engineering & -Mineral Economics \\
\hline & •Metallurgy \& Processing & •Feasibility Studies \\
\hline - CPRs & •Geology & -Due Diligence Studies \\
\hline & -Data Compilation - GIS & \\
\hline www.minxcon.co.za & Tel + 27(0) 119582899 & reception@minxcon.co.za \\
\hline
\end{tabular}




\section{classifieds}

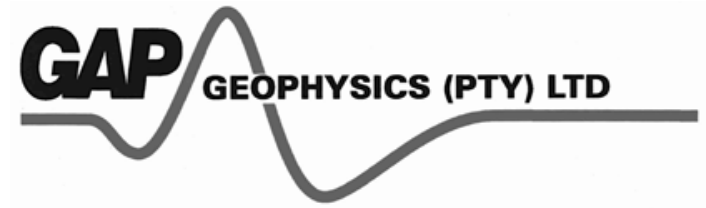

Geoff Campbell mвamsc Eng(ont) CONSULTING GEOPHYSICIST

P.O.Box 2347, Saxonwold 2132

Tel: (011) 486-3228 Fax: (011) 486-3229

Cellphone: 083-449 5516 E-mail: gapgeo@icon.co.za

\section{DUIK \\ LDG GEDPHYSICS (PTY) LTD}

\section{Geoff Campbell MBAMScPEng(ont)} MANAGING DIRECTOR

P.O.Box 2347, Saxonwold 2132 Tel: (011) 486-3228 Fax: (011) 486-3229 Cellphone: 083-449-5516 E-mail: gapgeo@icon.co.za

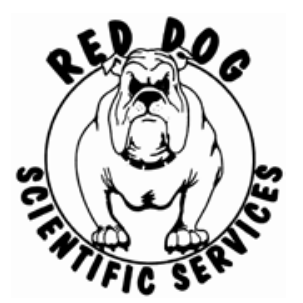

TERRY ODGERS

Ph: +27-(0)11-467-3371 reddog@geoafrica.co.za
Your one-stop shop for geological software and exploration equipment

-Borehole logging equipment \& software - Magnetometers, magnetic susceptibility meters, spectrometers

- Ground Penetrating Radar (GPR)

-3D visualization \& contouring software

Cellular : 0828929771 www.RedDogGeo.com

\section{Dr Sabine Verryn}

(PhD (Geology), Pr. Sci. Nat)

75 Kafue Street, Lynnwood Glen. 0081

Cell: 0835480586 Fax: 0865657368

e-mail: sabine.verryn@xrd.co.za

skype:sabine.xrd Website:www.xrd.co.za

Analytical and consulting services include:

- Phase identification of crystalline materials

- Phase quantification using the Rietveld method

- Glass (amorphous) content quantification

- Retained austenite quantification using the

Rietveld method

- Customer specific quality control methods - Powder Diffraction training courses

- Petrographic descriptions

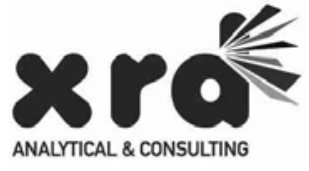

X-RAY POWDER DIFFRACTION SPECIALIST

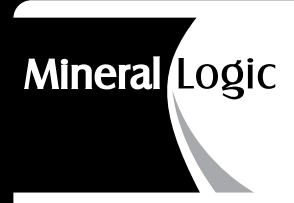

Paul Zweistro

BSc(Hons) Pr.Sci.Nat. FSEG, FGSSA

Consulting Diamond

Geologist
DIAMOND EXPLORATION CONSULTANCY

- Comprehensive Indicator Mineral Service - Petrography

- Project Management/Evaluation

- Geological Modelling

Mineral-Logic / VP3 Geoservices (Pty) Ltd

PO Box 542, Plettenberg Bay 6600, South Africa

Tel. Mob +27 824448424 Skype: paulgeologyl e-mail:pz@vp3.co.za

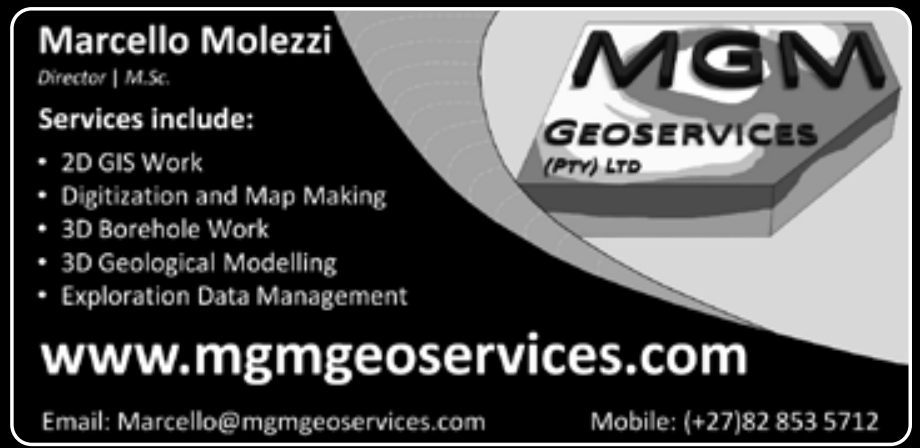

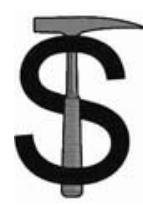

\section{ROCK ECONOMICS \\ Know your rock values}

DAVID R YOUNG

BSc (Hons), FGSSA, FAusIMM, FSAIMM, Pr Sci Nat Consultant Geologist

48 Riverview, Baviaanskloof Rd Scott Estate, Hout Bay, W Cape Land + 27 (0)21 7910265

PO BOX 27069

Hout Bay 7872

South Africa

401A The Jade, 10 Lower Rd

Morningside, Sandton, Gauteng Mobile + 27 (0)82 6502550

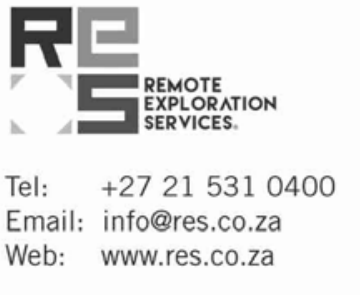

Remote Exploration Services

(RES) offers consulting and contracting services to exploration companies operating in Africa 


\section{classifieds}

\section{Allan E Saad} Msc Pr Sci Nat FGSSA

DUE DILIGENCE STUDIES PROJECT EVALUATION TARGET GENERATION
EXPLORATION GEOLOGIST SOUTH AFRICA

PO Box 35270

Menlo Park 0102

Pretoria

Tel: 0828817850

e-mail:

asaad@mweb.co.za

Explore Store (Pty) Ltd

trading as

\section{EXPLORE-IT}

Suppliers and Consultants to the Mineral Exploration and Drilling Industry

$+27836288686+27748022315$

cecilc@explore-it.co.za michelle@africore.co.za

TO ADVERTISE IN THE GEOBULLETIN CLASSIFIEDS:

email: info@gssa.org.za

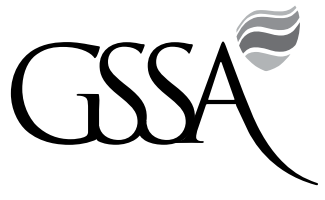

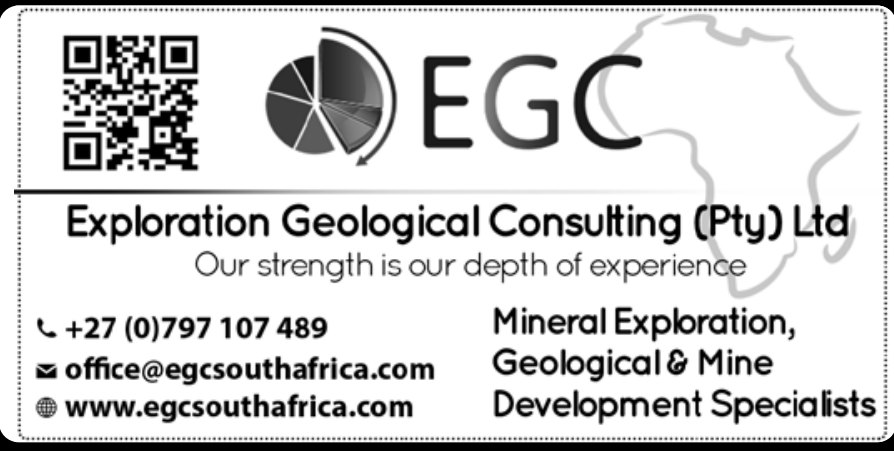

\section{GEMECS (Pty) Ltd}

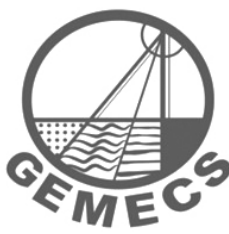

- Coal \& Mineral resource modelling and reporting

Exploration management and core logging services

- Geological database services

Prospect permit evaluations

Resource modelling training for GEOVIA Minex 292 Walter Sisulu street gemecs@gemecs.co.z $\begin{array}{ll}\text { Middelburg } & +27132430869 \\ \text { Mpumalanga } & +27836530864\end{array}$

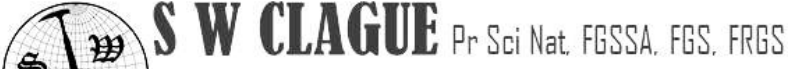 8 c) GeOLOGICAL CONSULTING}

40 vears'successfultrack record in multi-commodity exploration and mining

-Geological mapping and structural interpretation

-Desktop studies and geological due-diligence

-Metallogenic terrane analysis and target generation

- Optical mineralogy and ore petrography

-Training of staff in geological skills

Stuart Clague

+27(0)83 6091180 | swclague@gmail.com | P O Box 1022, Ifafi 0260, North West, South Africa 


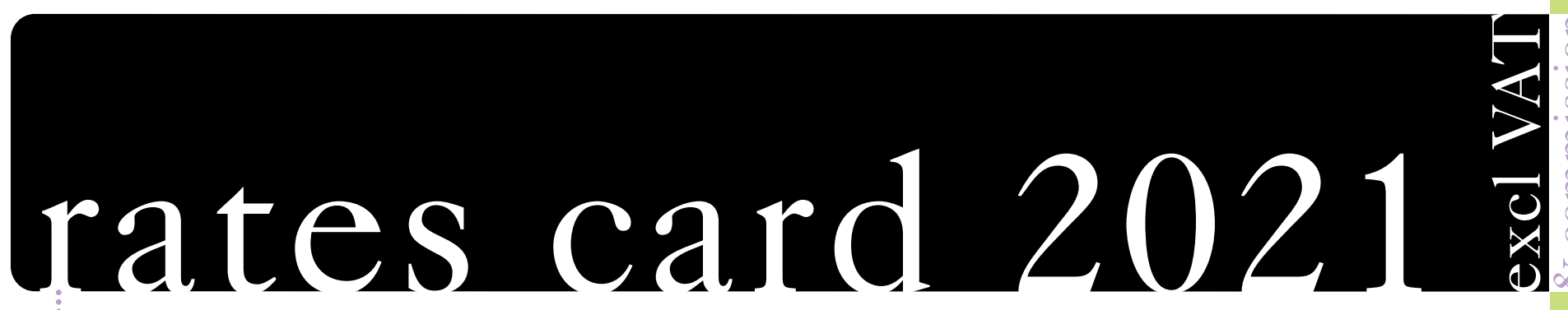

1. ADVERTISING RATES (Excl. VAT \& Agency Commission)

Geobulletin is published by the Geological Society of South Africa (GSSA) and appears quarterly during March, June, September and December each year.

\begin{tabular}{|c|c|c|}
\hline \multicolumn{2}{|l|}{ Black \& White } & \\
\hline Size & $\begin{array}{l}\text { Casual } \\
1-3 \text { insertions }\end{array}$ & $4+$ Insertions \\
\hline Full Page & R11 270.00 & R10 405.00 \\
\hline Half Page & R 7490.00 & R 6735.00 \\
\hline Quarter Page & R 4960.00 & R 4255.00 \\
\hline
\end{tabular}

\section{Colour}

Full-colour (F/C): B\&W page rate plus R4 620.00 Standard Spot Colour R2 268.00 extra per colour $\begin{array}{lll}\text { Full Pg F/C } & \text { R16 } 800.00 & \text { R16 } 050.00 \\ \text { Half Pg F/C } & \text { R13 } 105.00 & \text { R12 } 390.00\end{array}$ Quarter Pg F/C R10 355.00 R 9915.00 Special Positions

$$
\begin{array}{cc}
\text { Inside Front/Back } & \text { Outer Cover only } \\
\text { R25 } 190.00 & \text { R24 185.00 }
\end{array}
$$

Professional Directory: (Black \& white only)

$\begin{array}{lll}\text { Company: } & \text { R } 1015.00 & \text { R1 } 008.00 \\ \text { Individual: } & \text { R } 760.00 & \text { R } 745.00\end{array}$

Size: $45 \times 90 \mathrm{~mm}$ wide

Advertorial rate per column per $\mathbf{c m}$

Full column, \pm 500 words:

$$
\text { R3 } 560.00 \quad \text { R3 } 560.00
$$

\section{MECHANICAL DETAILS}

$\begin{array}{ll}\text { Trim Size: } & 297 \mathrm{~mm} \times 210 \mathrm{~mm} \\ \text { Full Bleed } & 297 \mathrm{~mm} \times 210 \mathrm{~mm}+5 \mathrm{~mm} \text { all round } \\ \text { Type Area: } & \text { Full Page: } 275 \mathrm{~mm} \times 190 \mathrm{~mm} \\ \text { Half Page: } & 275 \mathrm{~mm} \times 95 \mathrm{~mm} \text { (Vertical ad) } \\ & 135 \mathrm{~mm} \times 190 \mathrm{~mm} \text { wide (Horizontal ad) } \\ \text { Quarter Page: } & 135 \mathrm{~mm} \times 95 \mathrm{~mm} \text { (Vertical ad) } \\ \text { Screen: } & 300 \text { DPI or more } \\ \text { Material: } & \text { CD or High resolution PDF in CMYK }\end{array}$

\section{PRINTING MATERIAL}

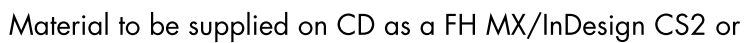
PDF file. Accompanying images should be high resolution in CMYK format (NO RGB or Pantone colours). Any full page material to be trimmed to $297 \times 210 \mathrm{~mm}$ must include a bleed of $5 \mathrm{~mm}$ all round. A COLOUR HARDCOPY MUST

ACCOMPANY MATERIAL. Any modifications to incorrectly supplied material will be charged to the advertiser at R300.00 per hour.

\section{LOOSE INSERTS}

R7 680.00 Printed material to be supplied. Please ensure that the inserts do not exceed the trim size of $297 \times 210 \mathrm{~mm}$. All inserts must be e-mailed to the GB Editor.

\author{
5. DEADLINES FOR COPY AND ADVERTISING MATERIAL \\ March issue: $\quad 15$ February 2021 \\ June issue: $\quad 15$ May 2021 \\ September issue: 14 August 2021 \\ December issue: 15 November 2021
}

\section{CANCELLATIONS}

At least 4 weeks prior to deadline

\section{CIRCULATION}

Geobulletin is issued in digital format to all members of the GSSA and its local and overseas exchange partners. A printed option is also available for those who opt for it, and the electronic version is available as an open access download on the GSSA website. Circulation exceeds 3150 recipients plus website visitors, and reaches decision makers in the geoscience community including industry, academia, and government.

\section{ADVERTISING BOOKINGS AND SUBMISSION \\ Contact person: GSSA \\ e-mail: lully.govender@gssa.org.za \\ accounts@gssa.org.za}

\section{ADDITIONAL CONTACT INFORMATION}

\section{EDITORIAL OFFICE}

Dr. T. Owen-Smith geobulletin@gssa.org.za

DESIGN \& LAYOUT

Belinda Boyes-Varley

cell: 0791297748

e-mail: bvmac@icon.co.za

\section{SOCIETY OFFICE}

\section{GSSA}

Mandela Mining Precinct (formerly CSIR MININGTEK),

Corner Rustenburg \& Carlow Roads,

Melville, Johannesburg, SOUTH AFRICA.

P.O. Box 91230

Auckland Park 2006

Johannesburg, South Africa

Tel: +2711358 0028

e-mail: info@gssa.org.za Web: www.gssa.org.za

The design and layout of the adverts is the responsibility of the advertiser. If you wish to utilise the services of the GB graphics and layout supplier, please contact Belinda directly, well in advance of the advert submission deadline to make arrangements. 
